\title{
Liene Elsone
}

\section{OPTISKĀ NEIROMIELĪTA KLĪNISKĀS NORISES UN ĀRSTËŠANAS RAKSTUROJUMS}

Promocijas darba kopsavilkums medicinas doktora zinātniskā grāda iegūšanai Specialitāte - neiroloǵija 


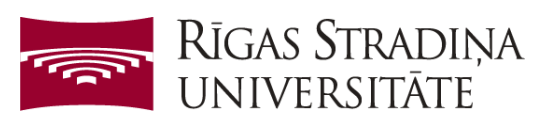

\author{
Liene Elsone
}

\title{
OPTISKĀ NEIROMIELİTA KLĪNISKĀS NORISES UN ĀRSTĒŠANAS RAKSTUROJUMS
}

\author{
Promocijas darba kopsavilkums \\ medicīnas doktora zinātniskā grāda iegūšanai
}

Specialitāte - neirologiija

Rīga, 2015 
Promocijas darbs izstrādāts Valtonas Neirolog̣ijas un neiroķirurǵijas centrā Liverpūlē, Lielbritānijā sadarbībā ar Rīgas Austrumu klīniskās universitātes slimnīcas klīniku “Gaiḷezers”, MS vienību.

Darba zinātniskie vadītāji:

Dr. med. profesors Ardis Platkājis, Rīgas Austrumu klīniskās universitātes slimnīcas klīnika "Gaiḷezers", Rīgas Stradiņa universitāte, Latvija Dr. med. docents Guntis Karelis, Rīgas Austrumu klīniskās universitātes slimnīcas klīnika "Gaiḷezers", Latvija

Darba zinātniskā konsultante:

Anu Jacob (FRCP), Valtonas Neiroloǵijas un neiroķirurğijas centrs, Liverpūle, Lielbritānija

Oficiālie recenzenti:

Dr. med. profesore Ināra Logina, Latvija

Dr. med. profesors Igors Aksiks, Latvija

Dr. med. profesore Katrin Gross-Paju, Igaunija

Promocijas darba aizstāvēšana notiks 2015. gada 7. decembrī plkst. 15.00 RSU Medicīnas promocijas padomes atklātā sēdē Rīgā, Dzirciema ielā 16, Hipokrāta auditorijā.

Ar promocijas darbu var iepazīties RSU bibliotēkā un RSU mājas lapā: www.rsu.lv

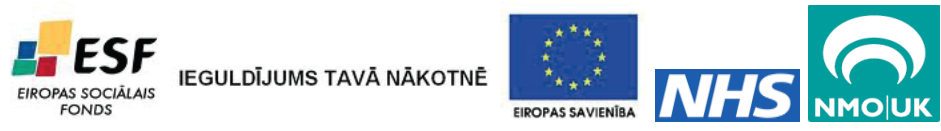

Promocijas darbs veikts ar ESF projekta "Atbalsts doktorantiem studiju programmas apguvei un zinātniskā grāda ieguvei RSU" un Lielbritānijas NHS nacionālās NMO programmas atbalstu

Promocijas padomes sekretāre:

Dr. med. Simona Donin̦a 


\section{SATURS}

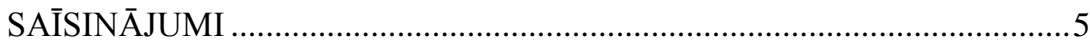

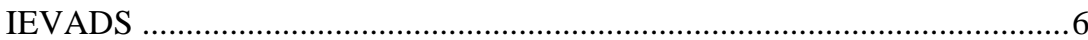

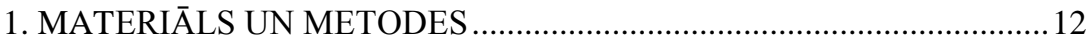

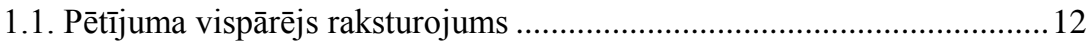

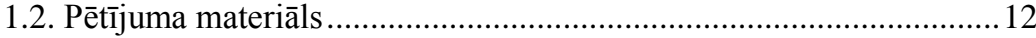

1.2.1. Pētījuma populācija un tās atlase ............................................... 12

1.2.2. Latvijas multiplās sklerozes reǵistra dati.................................. 13

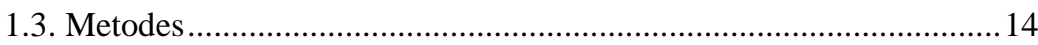

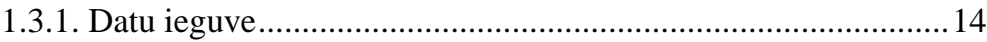

1.3.2. Neirologiskā stāvokḷa novērtējums............................................ 15

1.3.3. Ārstēšanas efektivitātes izvērtējums ........................................ 15

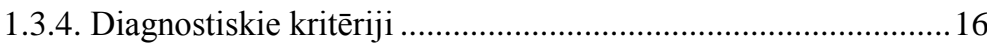

1.3.4.1. NMO diagnostiskie kritēriji ........................................ 16

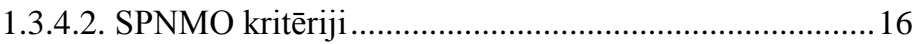

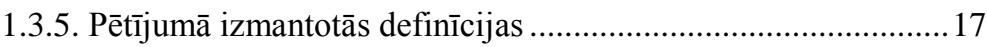

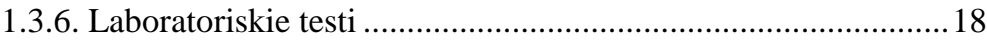

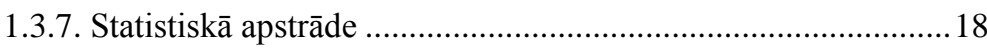

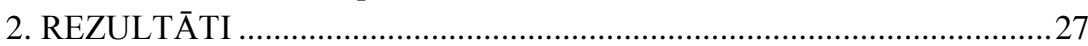

2.1. Optiskā neiromielīta klīniskais raksturojums ...................................27

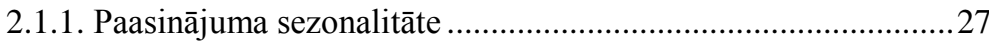

2.1.2. Pirmās klīniskās epizodes īpatnības........................................29

2.1.2.1. AQP4-IgG negatīvi gadījumi $(\mathrm{n}=27)$...........................30

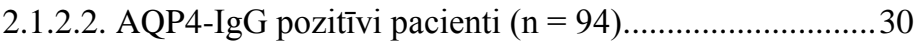

2.1.2.3. Pacienti ar pakāpenisku saslimšanas sākumu

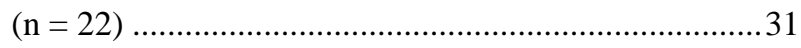

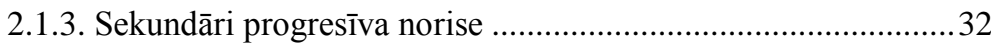

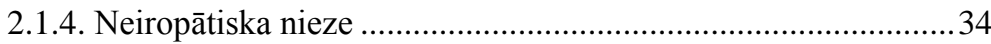

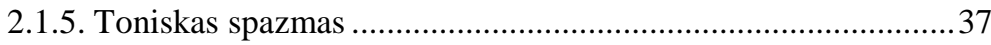

2.1.6. MOG-IgG pozitīvu pacientu fenotips .........................................38

2.2. Optiskā neiromielīta ārstēšanas raksturojums ....................................39

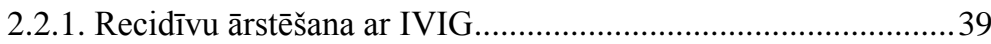

2.2.1.1. Pacientu raksturojums un IVIG indikācijas....................39

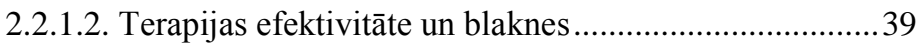

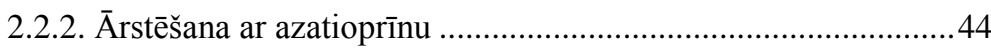

2.2.2.1. Pacientu un terapijas vispārējs raksturojums..................44 
2.2.2.2. Efektivitātes raksturojums: paasinājumu skaits 45

2.2.2.3. Efektivitātes raksturojums: invaliditāte jeb funkciju zudums 54

2.2.2.4. Ārstēšanas nepārtrauktība ............................................ 55

2.2.3. Latvijas MS reǵistrā ievadāmo datu analīze.............................. 56

2.2.3.1. MS reg̣istra vispārēja analīze ....................................... 56

2.2.3.2. Iespēja atklāt NMO un citu retu slimību variantus vai atipiskus simptomus .............................................. 57

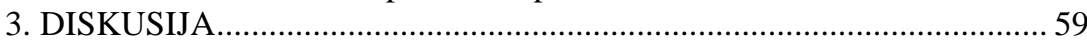

3.1. Optiskā neiromielīta klīniskais raksturojums .................................... 59

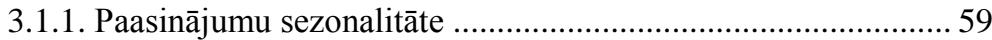

3.1.2. Pirmās klīniskās epizodes īpatn̄ības .......................................... 61

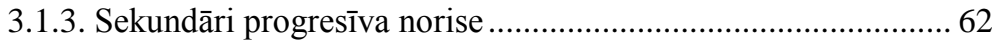

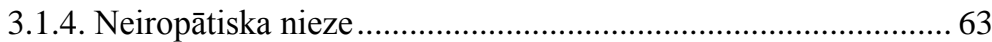

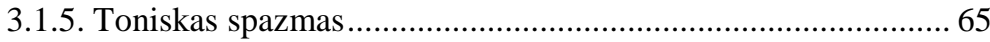

3.1.6. MOG-IgG pozitīvu gadījumu fenotips ................................... 67

3.2. Optiskā neiromielīta ārstēšanas raksturojums .................................. 69

3.2.1. Recidīvu ārstēšana ar intravenoziem imūnglobulīniem .......... 69

3.2.2. Ārstēšana ar azatioprīnu ........................................................ 70

3.3. Latvijas MS reǵistrā ievadāmo datu analīze .................................... 73

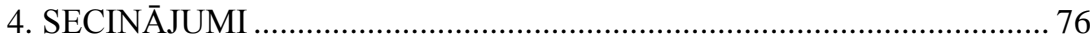

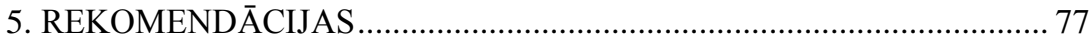

5.1. Klīniski praktiskās rekomendācijas NMO / NMOS slimnieku diagnostikas un ārstēšanas uzlabošanai ........................................ 77

5.2. Rekomendācijas Latvijas MS reǵistra kvalitātes uzlabošanai .......... 77

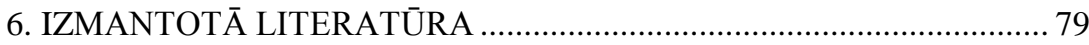

7. PUBLIKĀCIJAS UN ZIN̦OJUMI PAR PĒTĪJUMA TĒMU ................... 89

7.1. Zinātniskie raksti starptautiski citējamos žurnālos saistībā ar darba tēzēm (pirmais autors) ......................................................... 89

7.2. Konferenču tēzes publicētas starptautiski citējamos žurnālos saistībā ar darba tēzēm (pirmais autors) ............................................. 89

7.3. Publikācijas (zinātniskie raksti) par pētîjuma tēmu ........................... 90

7.4. Konferenču tēzes par pētījuma tēmu................................................ 92

7.5. Ziņojumi konferencēs par darba rezultātiem ..................................... 94

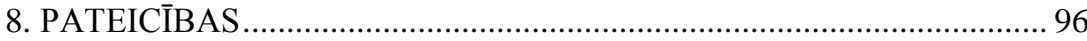




\section{SAĪSINĀJUMI}

\begin{tabular}{|c|c|}
\hline $\begin{array}{l}\text { ANMO - optiskais neiromielīts ar } \\
\text { izteiktu slimības aktivitāti } \\
\text { AQP4 - akvaporīns } 4 \\
\text { AZA - azatioprīns } \\
\text { BUS - Birmingemas universitātes } \\
\text { slimnīca } \\
\text { C - cervikāls } \\
\text { CBA - uz šūnu analīzi balstīts tests } \\
\text { (cell based assay) } \\
\text { DS - demielinizējoša saslimšana } \\
\text { EDSS - izvērstā invaliditātes statusa } \\
\text { skala } \\
\text { GU - gaismas uztvere } \\
\text { IgG - imūnglobulīns G } \\
\text { IVIG - intravenozi imūnglobulīni } \\
\text { IVMP - intravenozs metilprednizolons } \\
\text { IQR - iekšējais kvartillu diapazons } \\
\text { TPMT - tiopurīna metiltransferāze } \\
\text { KCP - kraniocervikālā pāreja } \\
\text { KI - konfidences intervāls } \\
\text { KRS - kopējais recidīvu skaits } \\
\text { KS - kortikosteroīdi } \\
\text { LJMC - Latvijas Jūras medicīnas } \\
\text { centrs } \\
\text { LM - longitudināls mielīts } \\
\text { MANMO - optiskais neiromielīts ar } \\
\text { mazāk izteiktu slimības aktivitāti } \\
\text { max - maksimālā vērtība } \\
\text { min - minimālā vērtība } \\
\text { MO - iegarenās smadzenes } \\
\text { MOG - mielīna oligodendrocītu } \\
\text { glikoproteīns } \\
\text { MRC - medicīnas zinātniskās padomes } \\
\text { vērtējuma sistēma } \\
\text { MR - magnētiskā rezonanse } \\
\text { MS - multiplā skleroze } \\
\text { NGU - pilnīgs aklums, gaismas } \\
\text { uztvere nav iespējama } \\
\text { NMO - optiskais neiromielīts }\end{array}$ & $\begin{array}{l}\text { NHS - Lielbritānijas Nacionālā } \\
\text { veselības aprūpes sistēma } \\
\text { NMOS - optiskā neiromielīta spektrs } \\
\text { NN - neiropātiska nieze } \\
\text { NZ - nav zināms } \\
\text { OCB - oligoklonālās kēèdes } \\
\text { ON - redzes nerva neirīts } \\
\text { PKE - pirmā klīniskā epizode } \\
\text { PLEX - plazmaferēze } \\
\text { p/o - iekšksīgi jeb perorāli } \\
\text { RAKUS - Rīgas Austrumu klīniskāa } \\
\text { universitātes slimnīca "Gail̦ezers" } \\
\text { RRMS - recidivējoši remitējoša } \\
\text { multiplā skleroze } \\
\text { RS - Džona Radklifes slimnīca } \\
\text { RSG - vidējais recidīvu skaits gadā } \\
\text { S - sieviete } \\
\text { SD - standarta deviācija } \\
\text { Sm. st. boj. - smadzeņu stumbra } \\
\text { bojājums } \\
\text { SNNMO - smagi noritošs optiskais } \\
\text { neiromielīts } \\
\text { SP - sekundāri progresīva norise } \\
\text { SPKC - slimību profilakses un } \\
\text { kontroles centrs } \\
\text { SPNMO - sekundāri progresīvs } \\
\text { NMO } \\
\text { SSK-10 - starptautiskā slimību } \\
\text { klasifikatora 10. redakcija } \\
\text { Th - torakāls } \\
\text { TM - transversāls mielīts } \\
\text { TS - toniskas spazmas } \\
\text { T2 - T2 uzsvērtie attēli magnētiskā } \\
\text { rezonansē } \\
\text { V - vīrietis } \\
\text { VUS - Velsas Universitātes slimnīca } \\
\text { VNNC - Valtonas Neiroloğijas un } \\
\text { neiroksirurğijas centrs }\end{array}$ \\
\hline
\end{tabular}




\section{IEVADS}

\section{Problēmas aktualitāte}

Optiskais neiromielīts (NMO) jeb Devika slimība ir salīdzinoši reta, tomēr otra biežākā (aiz multiplās sklerozes jeb MS) no demielinizējošām CNS slimībām. Augstas MS prevalences valstīs konstatē 1 gadījumu uz katriem 40-100 MS slimniekiem (Wingerchuk, Lennon et al. 2006, Bichuetti, Rivero et al. 2008, Asgari, Lillevang et al. 2011). Ilgus gadus NMO tika uzskatîts par MS variantu. Kopš specifisko patoǵenētisko antivielu (NMO-IgG jeb AQP4-IgG) atklāšanas šiem slimniekiem (konstatē 70-90\%), NMO tiek uzskatīts par atsevišķu slimību (Lennon, Wingerchuk et al. 2004). Savukārt salīdzinoši nesen dą̧ai AQP4-IgG negatīvu slimnieku serumā konstatētas citas specifiskas (iespējams patoǵenētiskas) antivielas - anti MOG-IgG, kas pēc atsevišksu pētnieku domām, iespējams, reprezentē vieglāku slimības gaitu un monofāzisku norisi (Kitley, Woodhall et al. 2012, Kitley, Waters et al. 2014, Saadoun, Waters et al. 2014)). Likumsakarīgi, ka tā rezultātā rodas jautājums, vai MOG-IgG līdzīgi kā AQP4-IgG var tikt izmantots kā biomarķieris slimības turpmākās prognozes noteikšanai?

Vairumā NMO gadījumu slimība izpaužas ar atkārtotiem paasinājumiem, savukārt katrs jauns NMO uzliesmojums var novest līdz izteiktai invaliditātei vai pat nāvei (Wingerchuk, Hogancamp et al. 1999, Wingerchuk and Weinshenker 2003). Tiek pieņemts uzskatīt, ka progresējoša slimības norise, kas ir viens no noteicošajiem faktoriem invaliditātes attīstībā MS slimniekiem, nav NMO raksturīga (Trojano, Avolio et al. 1995, Bergamaschi, Berzuini et al. 2001, Confavreux, Vukusic et al. 2003, Leray, Yaouanq et al. 2010). Līdz šim ir tikai viens pētījums (pirms 8 gadiem) par sekundāri progresējošas norises biežumu NMO slimniekiem; tā novērota tikai 2\% gadījumu (Wingerchuk, Pittock et al. 2007). Arī progresējošs saslimšanas sākums (pirmā paasinājuma simptomu attīstība vairāku mēnešu garumā) līdz šim ir aprakstîts tikai vienā klīniskā gadījumā (Woo, Chiu et al. 2014). MS slimnieku slimības aktivitātē vērojamas sezonālas svārstības, nereti ar stacionēto slimnieku skaita pieaugumu tieši gada ,siltajos" mēnešos (Bamford, Sibley et al. 1983, Jin, de Pedro-Cuesta et al. 2000, Koziol and Feng 2004, Ogawa, Mochizuki et al. 2004, Abella-Corral, Prieto et al. 2005, Fonseca, Costa et al. 2009, Balashov, Pal et al. 2010, Meier, Balashov et al. 2010, Salvi, Bartolomei et al. 2010, Handel, Disanto et al. 2011, Damasceno, Von Glehn 
et al. 2012, Iuliano 2012, Hart and Gorman 2013, Muto, Mori et al. 2013, Spelman, Gray et al. 2014). Par NMO sezonalitātes tendencēm līdz šim ir tikai viens ziņojums, tomēr tā rezultāti ir vērtējami pretrunīgi (Muto, Mori et al. 2013).

NMO, līdzīgi optikospinālai MS, klasiski izpaužas ar redzes zudumu un mielītu, tomēr pēdējos gados ir daudz ziņojumu arī par smadzeņu stumbra bojājumu, kas nereti izpaužas ar profūzu vemšanu un žagošanos (Kremer, Mealy et al. 2013). Ir ziņojumi arī par simptomātisku narkolepsiju, hipotermiju, dzirdes traucējumiem, izteiktu sāpju sindromu, toniskām spazmām, neiropātisku niezi u. c. simptomiem (Baba, Nakashima et al. 2009, Kanbayashi, Shimohata et al. 2009, Sato and Fujihara 2011, Iyer, Elsone et al. 2014, Suzuki, Nakamura et al. 2012, Nakano, Dei et al. 2014, Jarius, Lauda et al. 2013, Kremer, Mealy et al. 2013, Gratton, Amjad et al. 2014, Takanashi, Misu et al. 2014, El Otmani, Dany et al. 2015, Wang, Qi et al. 2015, Wingerchuk, Hogancamp et al. 1999, Kim, Go et al. 2012, Usmani, Bedi et al. 2012, Abaroa, Rodriguez-Quiroga et al. 2013). Nereti šie ziņojumi (t. sk. par toniskām spazmām, neiropātisku niezi) aprobežojas tikai ar atsevišķ klīnisko gadījumu aprakstiem, tādēl nav zināms, vai tie ir NMO slimību raksturojoši. Svarīgi atzīmēt, ka daudzas klīniskās, laboratoriskās un radiologiskās pazīmes abām slimībām ir līdzịgas, tādēl joprojām NMO nereti sākotnēji tiek kḷūdaini diagnosticēts kā MS. Lai nodrošinātu agrīnu NMO diagnostiku, svarīgi ir izpētīt un noskaidrot NMO norises īpatnības un raksturīgus unikālus simptomus.

Ārstēšana abos gadījumos ir atšķirīga. NMO paasinājumu ārstēšanai jābūt savlaicīgai un agresīvai. To tipiski uzsāk ar augstām kortikosteroīdu devām un to nepietiekamas efektivitātes gadījumā - plazmaferēzi (Palace, Leite et al. 2012, Jacob, McKeon et al. 2013). Citu iekaisīgu un antivielu mediētu slimību (piemēram, miastēnijas, GBS u. c.) akūtā ārstēšanā efektīvi pielieto arī intravenozos imūnglobulīnus (IVIG), kas teorētiski varētu būt alternatīvs ārstēšanas līdzeklis arī NMO slimniekiem (Jacob, McKeon et al. 2013, Mealy, Wingerchuk et al. 2014). Līdz šim ir bijuši ziṇojumi par IVIG lietošanu NMO slimniekiem tikai starprecidīvu periodā, lai samazinātu turpmāku paasinājumu risku (Bakker and Metz 2004, Okada, Tsuji et al. 2007, Magraner, Coret et al. 2013, Wingerchuk 2013). Vai IVIG ir efektīvi un droši, pielietojot NMO paasinājumu akūtā terapijāa, ziņojumu nav.

Arī savlaicīgi neuzsākot ilgstošu imūnmodulējošu terapiju vai lietojot medikamentus, kas paredzēti MS ārstēšanai, Devika slimība recidivē (Palace, 
Leite et al. 2010, Jacob, Hutchinson et al. 2012, Palace, Leite et al. 2012). NMO imūnmodulējošas terapijas izvēle balstās uz atsevišķu gadījumu aprakstiem un klīnicistu iepriekšējo pieredzi. Randomizēti, placebo kontrolēti pêtījumi, būtu neētiski slimības smagās norises un augstās invaliditātes un letalitātes dēḷ. Azatioprīns ir lēts, plaši pieejams un tādēl viens no plašāk lietotajiem imūnsupresīviem medikamentiem NMO slimības ārstēšanā ar jau iepriekš pierādītu efektivitāti (Mandler, Ahmed et al. 1998, Bichuetti, Lobato de Oliveira et al. 2010, Costanzi, Matiello et al. 2011). Tomēr tā pārtraukšanas iemesli un lietošanas ilgums, kā arī efektivitāte NMO slimniekiem ar dažādu slimības aktivitāti iepriekš nav pētīti. Pārliecinošu datu par to, vai azatioprīna lietošana tiek pārtraukta galvenokārt samazinātas efektivitātes vai arī blakṇu profila un nepanesamības dēḷ, literatūrā nav pieejami.

Atsevišķi autori ziṇo par NMO gadījumu retrospektīvu atklāšanu, izmantojot lokālos DS vai MS registrus (Cossburn, Tackley et al. 2012, Pandit, Mustafa et al. 2013). Nereti MS un / vai NMO reǵistru dati kalpo par materiālu NMO pētījumos (Collongues, Marignier et al. 2010, Cossburn, Tackley et al. 2012, Simon, Schmidt et al. 2014). Arī Latvijā darbojas MS registrs. Vai, izmantojot tā datus, iespējams atklāt NMO gadījumus arī Latvijāa, līdz šim nav pètīts.

\section{Darba mērḳis}

Šī darba mērķis ir padzilināti izpētît un raksturot NMO / NMOS klīniskās norises īpatnības un ārstēšanas efektivitāti, kā arī Latvijas MS reǵistrā ievadāmos datus, ar nolūku uzlabot NMO / NMOS pacientu diagnostiku, ārstēšanu un slimības iznākumu.

\section{Darba uzdevumi}

1. Izpētìt un raksturot NMO / NMOS klīniskās norises īpatnības:

- NMO paasinājumu sezonalitātes tendences;

- progresējošas slimības norises biežumu un īpatnības;

- neiropātiskās niezes un tonisku spazmu biežumu un īpatnības;

- MOG-IgG antivielu pozitīvu pacientu fenotipu.

2. Noskaidrot NMO/NMOS ārstēšanas efektivitāti:

- intravenozu imūnglobulīnu (IVIG) efektivitāti NMO paasinājumu ārstēšanā; 
- azatioprīna (AZA) efektivitāti kā imūnmodulējošam medikamentam NMO / NMOS slimniekiem ar dažādu slimības aktivitāti.

3. Veikt Latvijas MS reǵistrā iekḷaujamo datu kvalitātes un kvantitātes analīzi NMO / NMOS gadījumu atklāšanā.

\section{Darba hipotēzes}

1. NMO / NMOS paasinājumiem, līdzīgi kā MS, ir sezonāls raksturs.

2. Neiropātiska nieze un toniskas spazmas ir bieži un raksturojoši simptomi NMO / NMOS slimniekiem, un var būt kā paasinājuma indikators, savukārt progresējoša slimības norise ir reta un nav slimību raksturojoša.

3. Pretēji iepriekš uzskatītajam, MOG-IgG pozit̄̄viem NMO slimniekiem raksturīga gan monofāziska, gan recidivējoša norise ar dažādas pakāpes neirologisko funkciju zudumu.

4. Intravenozi imūnglobulīni un azatioprīns ir efektīvi medikamenti NMO / NMOS ārstēšanā, tomēr to efektivitāte atšķiras atkarībā no slimības iepriekšējās aktivitātes un / vai uzsākšanas savlaicīguma.

5. Latvijas MS reǵistra datu kvalitāte un apjoms ir nepietiekami, lai retrospektīvi atklātu NMO gadījumus.

\section{Darba zinātniskā novitāte un praktiskā nozīmība}

NMO ir salīdzinoši reta CNS saslimšana, bet savlaicīgi nediagnosticēta un neārstēta - ar augstu letalitāti un invaliditātes risku. Lai no tā izvairītos, ir svarīgi atpazīt šīs slimības klīniskās īpatnības, apzināt potenciālus un efektīvus ārstēšanas līdzekļus. Īpaši nozīmīgi šķita noskaidrot un raksturot NMO klīniskās īpatnības un to nozīmi slimības diagnostikā, par kurām pašreizējā literatūrā informācija nav pieejama vai arī tā ir niecīga.

Tādējādi, apkopojot promocijas darbā iegūtos rezultātus:

1. Pirmreizēji raksturotas vairākas NMO klīniskās pazīmes, kas varētu ietekmēt agrīnu NMO gadījumu diagnostiku un līdz ar to savlaicīgu ārstēšanu:

- pirmo reizi pasaulē izpētīta NMO / NMOS paasinājumu sezonalitāte rietumu populācijā;

- atklāts unikāls slimību raksturojošs simptoms - neiropātiska nieze un izpētīts tās biežums un īpatnības; 
- pirmo reizi pasaulē noskaidrots, ka pirmās klīniskās epizodes simptomu attīstība var noritēt arī progresējoši vairāku mēnešu garumā, kā arī noskaidrots progresējoši noritošas pirmās klīniskās epizodes biežums;

- pirmo reizi pasaulē raksturota MOG-IgG pozitīvu NMO gadījumu sērija ar recidivējošu norisi un izteiktu funkciju deficitu;

- noskaidrots tonisku spazmu un sekundāri progresējoši noritoša NMO biežums un īpatnības.

2. Veikts līdz šim pasaulē lielākais pētījums par azatioprīna efektivitāti NMO / NMOS, t. sk. pētījuma rezultāti balstīti vienīgi uz AQP4-IgG pozitīviem gadījumiem. Pirmo reizi pasaulē izvērtēts tā lietošanas ilgums un ar medikamenta pārtraukšanu saistītie faktori, kā arī efektivitāte NMO / NMOS slimniekiem ar dažādu slimības aktivitāti.

3. Pirmo reizi pasaulē izpētīta un aprakstìta intravenozo imūnglobulīnu efektivitāte un iespējamie riski NMO / NMOS pacientiem akūtu paasinājumu ārstēšanā, tādējādi paverot jaunas terapijas iespējas.

4. Darba rezultātā izstrādātas arī klīniski praktiskās rekomendācijas NMO / NMOS diagnostikas un ārstēšanas uzlabošanai.

5. Pirmo reizi Latvijā veikta detalizēta analīze par Latvijas MS reǵistrā iekḷaujamo datu kvalitāti un kvantitāti, lai noskaidrotu, vai tie ir pietiekami retrospektīvai potenciālu NMO / NMOS gadījumu atklāšanai, tādējādi aktualizējot jautājumu par MS registra pilnveidošanu, kā arī NMO pacientu atklāšanas iespējām Latvijā. Izstrādātas rekomendācijas Latvijas MS reǵistra uzlabošanai.

\section{Darba struktūra un apjoms}

Darbs uzrakstîts latviešu valodā. Tam ir sekojošas daļas: ievads, darba aktualitāte, darba mērķis, darba uzdevumi, izmantotais materiāls un metodes, iegūtie rezultāti un to apspriešana ar literatūras datiem, galvenie izdarītie secinājumi un rekomendācijas. Literatūras sarakstā ietverti 334 darbu nosaukumi. Kopējais darba apjoms (neskaitot izmantotās literatūras sarakstu un pielikumus) ir 137 lappuses, darbā ir 33 tabulas un 15 attēli. Par disertācijas materiālu publicēti 8 darbi, kopējais publikāciju skaits par darba tēmu -31 . 


\section{Personiskais ieguldījums}

Autore pastāvīgi izstrādājusi VNNC (Liverpūle, Apvienotā Karaliste) NMO pacientu datu bāzi, kā arī vākusi un apkopojusi tajā iekļaujamos datus par pacientiem ar NMO, NMOS un aizdomu NMO, t. sk. anketu izveidi, kā arī veikusi medicīniskās dokumentācijas analīzi, pacientu intervijas, objektīvu neiroloǵisku izmeklēšanu. Autore piedalījusies Apvienotās Karalistes nacionālā NMO pētījuma izpildē par pacientu klīnisko raksturojumu, laboratoriskām izmeklēšanas metodēm un izmantotās ārstēšanas efektivitāti. Autore ir iniciatore vairākiem apakšpētījumiem, piedalījusies pētījuma dizaina izstrādē, kā arī pētījuma ietvaros ieguvusi, sistematizējusi, apstrādājusi un analizējusi iegūtos datus.

Autore patstāvīgi veikusi Latvijas MS slimnieku reǵistra datu analīzi, vākusi, apkopojusi, sistematizējusi un analizējusi pacientu klīniskos datus, kā arī pati aktīvi piedalījusies MS un NMO pacientu diagnostikā un ārstēšanā.

\section{$\bar{E}$ tiskie aspekti}

Pētījums nav saistīts ar ētiska rakstura problēmām. Pacienti netika pakḷauti nekādiem papildu eksperimentiem vai izmeklējumiem. Darbā tika izmantoti ikdienas praksē veikto izmeklējumu un ārstēšanas rezultātu dati, kā arī izmeklējumu metodes, kas dod papildu svarīgu informāciju diagnostikas un ārstēšanas rezultātu uzlabošanai. Pētījuma pirmā daļa (par NMO klīniskām pazīmēm un ārstēšanu) veikta Lielbritānijas nacionālā NMO pētījuma ietvaros, kas 2003. gadā reǵistrēts regínālā ètikas komitejā (MREC02/8/082) Mančestrā, Lielbritānijāa kā ar̄̄ VNNC zinātniskās darbības pārraudzības komitejā (Liverpūle, Lielbritānija). Otrā dą̧a (Latvijas MS reǵistra analīze) veikta pētījuma "Demielinizējošo saslimšanu epidemiologisko, klīnisko un laboratorisko rādītāju raksturojums Latvijāa" ietvaros, kas registrēts Rīgas Stradiņa universitātes Ētikas komitejā 25.10.2012.

Pêtījuma daḷā par NMO klīnisko raksturojumu un ārstēšanu izmantoti tikai to pacientu dati, kas devuši rakstisku pacientu informēto piekrišanu. Tikai viens pacients atteica dalību pētîjumā, un tā dati turpmākā analīzē netika iekḷauti. 


\section{MATERIĀLS UN METODES}

\subsection{Pētījuma vispārējs raksturojums}

Šis pētījums veikts divās daḷās. Pirmā daļa raksturo NMO klīnisko norisi (paasinājumu sezonalitāti, pirmās klīniskās epizodes, progresējošas norises, neiropātiskas niezes un tonisku spazmu īpatnības, MOG-IgG pozitīvu pacientu fenotipu) un ārstēšanas efektivitāti (IVIG efektivitāti paasinājumu akūtā ārstēšanā un azatioprīna efektivitāti kā imūnmodulējošam medikamentam turpmāku paasinājumu riska samazināšanai/novēršanai). Tā veikta nacionālās NMO programmas ietvaros Valtonas Neirologijas un neiroķirurǵijas centrā (VNNC) Liverpūlē Lielbritānijā laika periodā no 2011. līdz 2014. gadam, darbojoties šajā centrā kā klīniskajam zinātniskajam līdzstrādniekam. VNNC ir terciārs veselības aprūpes pakalpojumu sniedzējs un NHS ietvaros pilda nacionālā NMO centra funkcijas. Uz centru nosūta pacientus no Lielbritānijas ziemeļu un rietumu dą̧as, Velsas ziemeļu dạ̧as, kā arī no Skotijas. NMO pacientu aprūpi pārējā Lielbritānijas dạ̧ā nodrošina Džona Radklifes slimnīca Oksfordā. Velsas dienvidos aprūpi šiem slimniekiem piedāvā arī Velsas Universitātes slimnīca Kārdifā. Šie centri arī piedalījās pacientu rekrutēšanā.

Otrā pētījuma dạ̦ā ietilpst analīze par Latvijas MS reǵistrā iekḷaujamo datu kvalitāti un kvantitāti un to izmantošanu potenciālu NMO / NMOS gadījumu retrospektīvai atklāšanai. Šis pētījums veikts projekta "Demielinizējošo saslimšanu epidemioloǵisko, klīnisko un laboratorisko rādītāju raksturojums Latvijā̄" ietvaros.

\subsection{Pētījuma materiāls}

\subsubsection{Pētījuma populācija un tās atlase}

Pētījuma pirmajā daḷā analizēti NMO / NMOS slimnieki (diagnoze apstiprināta atbilstoši vispārpieņemtajiem kritērijiem (Wingerchuk, Lennon et al. 2006), kas reǵistrēti kādā no lokālajām NMO datu bāzēm (Liverpūle, Oksforda vai Kārdifa).

Slimnieku atlases nosacījumi katra pētījuma uzdevuma izpildei ir atšķirīgi, detalizētāku aprakstu skat atsevišķi (1.1. tabula). Citos medicīniskos centros (RS, VUS, BUS) atlasīto pētījuma slimnieku dati, kā arī pacientu neiroloǵiskā izmeklēšana (paasinājumu sezonalitātes un azatioprīna efektīvi- 
tātes pētījumam) veikta katrā lokālā medicīnas centrā atsevišķi, iesniegtā informācija apkopota un analizēta VNNC.

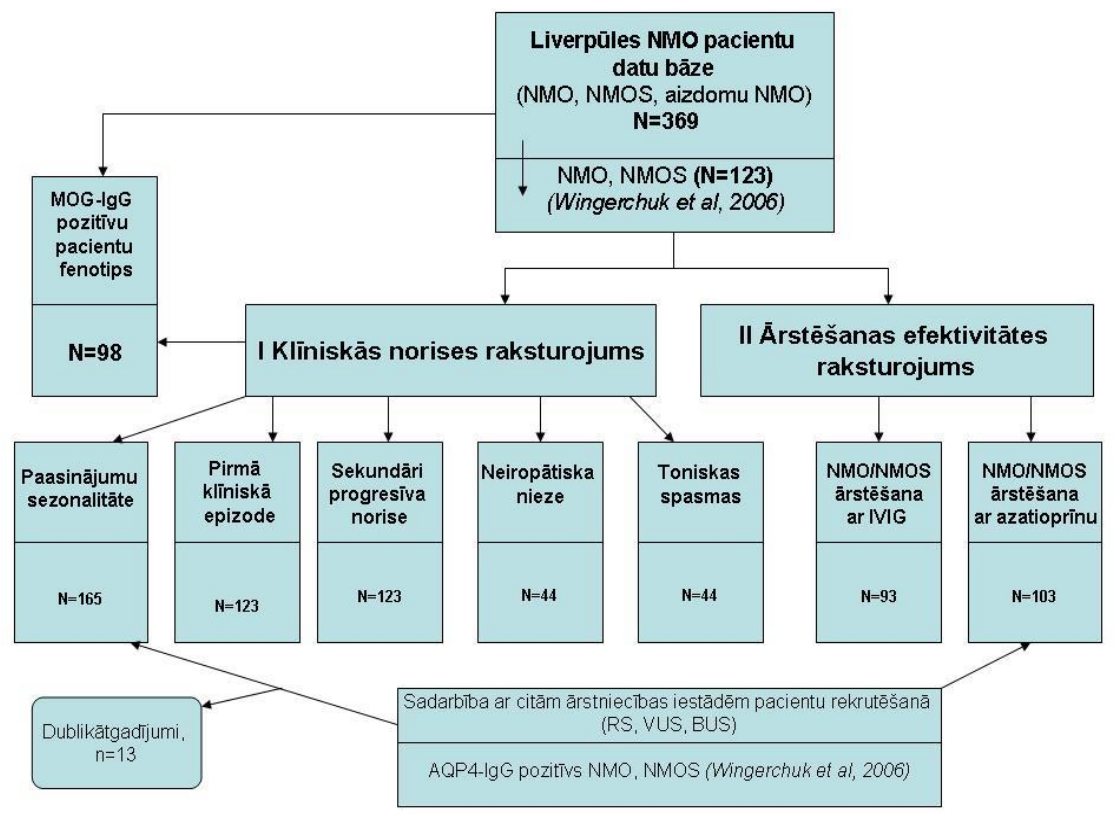

1.1. attēls. Pacientu plūsmas shematisks atspoguḷojums

NMO - optiskais neiromielīts, NMOS - optiskā neiromielīta spektrs, $\mathrm{N}$ - gadījumu skaits, RS - Džona Radklifes slimnīca, VUS - Velsas Universitātes slimnīca, BUS - Birmingemas Universitātes slimnīca, IVIG - intravenozi imūnglobulīni, AQP4-IgG - antiakvaporīna 4 antivielas

\subsubsection{Latvijas multiplās sklerozes reǵistra dati}

Latvijas MS reǵistra analīzei izmantota Latvijas MS pacienta kartē iekḷaujamā informācija (Ministru Kabineta 2008. gada 15. septembra noteikumi Nr. 746; 13. pielikums), kas ir par pamatu datu ievadei registrā, kā arī autores personīgā pieredze, strādājot kā neirologam Latvijas Jūras medicīnas centrā (līdz šim vienīgais MS datu operators) laika posmā no 2003. līdz 2010. gadam. 


\subsection{Metodes}

\subsubsection{Datu ieguve}

Pētījumā izmantotas klīniskās (pacientu datu ieguve un analīze, neirologiska izmeklēšana) un laboratoriskās (seroloǵiska izmeklēšana) metodes. Pētījumā iegūti šādi dati: demogrāfiskie rādītāji (vecums, dzimums, etniskā grupa); klīniskie dati (paasinājumu datums un raksturojums, t. sk. novērotie simptomi un to izteiktības pakāpe, attīstības ilgums, saņemtā ārstēšana, neirolog̣iskās izmeklēšanas rezultāti, funkciju atjaunošanās pakāpe pēc recidīva (visi paasinājumi tika kategorizēti pa grupām atkarībā no to registrēšanas datuma precizitātes, respektīvi - precizitāte pa dienām, nedēlāam, mēnešiem, gadiem, dekādes; tikai epizodes ar precizitāti 0-30 dienas iekḷautas pētījumā); papildus klīniskie dati par specifiskiem simptomiem, t. sk. smadzenuu stumbra bojājuma simptomiem, neiropātisku niezi, toniskām spazmām; niezes raksturojums, t. sk. dati par blakus saslimšanām (lai izslēgtu gadījumus, kad nieze saistīta ar dermatologiskām problēmām vai sistēmisku saslimšanu), norises īpatnībām un pavadošām pazīmēm, niezes intensitāti (pēc numeroloǵiskās sāpju skalas, 0-10), niezes saistība ar citām neiroloǵiskām pazīmēm un MR atradni; tonisku spazmu raksturojums, t. sk., datums, kad TS attīstījās, spazmu lokalizācija, TS biežums un ilgums, pavadošās pazīmes, intensitāte diennakts laikā, izraisītājfaktori, sanemtā ārstēšana, saistība ar citiem mielīta simptomiem (izvērtēta TS savstarpējā saistība ar neiroloǵiskām pazīmēm un MR atradni); dati par saņemto imūnmodulējošo / imūnsupresīvo terapiju, t. sk. IVIG efektivitāte un panesamība, uzsākšanas datums, AZA efektivitāte, panesamība, lietošanas ilgums, pārtraukšanas iemesli; laboratorisko izmeklējumu dati (t. sk. AQP4-IgG un MOG-IgG statuss, likvora izmeklējumi, hematoloǵiskie rādītāji ārstēšanas periodā u. c.); radiolog̣isko izmeklējumu dati (izvērtēti kopā ar neiroradiologu VNNC radiolog̣ijas nodaḷāa).

Visu pētījumā iekḷauto pacientu dati (demogrāfiskie un klīniskie rādītāji, izmeklējumu rezultāti, kā arī dati par saņemto ārstēšanu) iegūti retrospektīvi vai prospektīvi, iztaujājot pacientus pēc iepriekš izstrādātām datu anketām. Iegūtā informācija salīdzināta ar ierakstiem medicīniskā dokumentācijā un ievadīta Liverpūles NMO pacientu datu bāzē. Nepieciešamības gadījumā informācija precizēta, un papildu dati iegūti no pacientu aprūpē iesaistītiem ǵimenes ārstiem, neirologiem u. c. speciālistiem vai veicot pacientu intervijas kārtējās pieņemšanas, mājas vizītes apmeklējuma laikā vai telefoniski. Pētījuma datu 
ieguves metožu vispārēju atspoguḷojumu skat. 1.2. attēlā. Kopsavilkums par pêtījuma materiālu un izmantotām metodēm atspoguḷots 1.1. tabulā. Slimnieku atlases nosacījumi katra pētījuma uzdevuma izpildei ir atškirīgi, detalizētāku aprakstu skat atsevišşi.

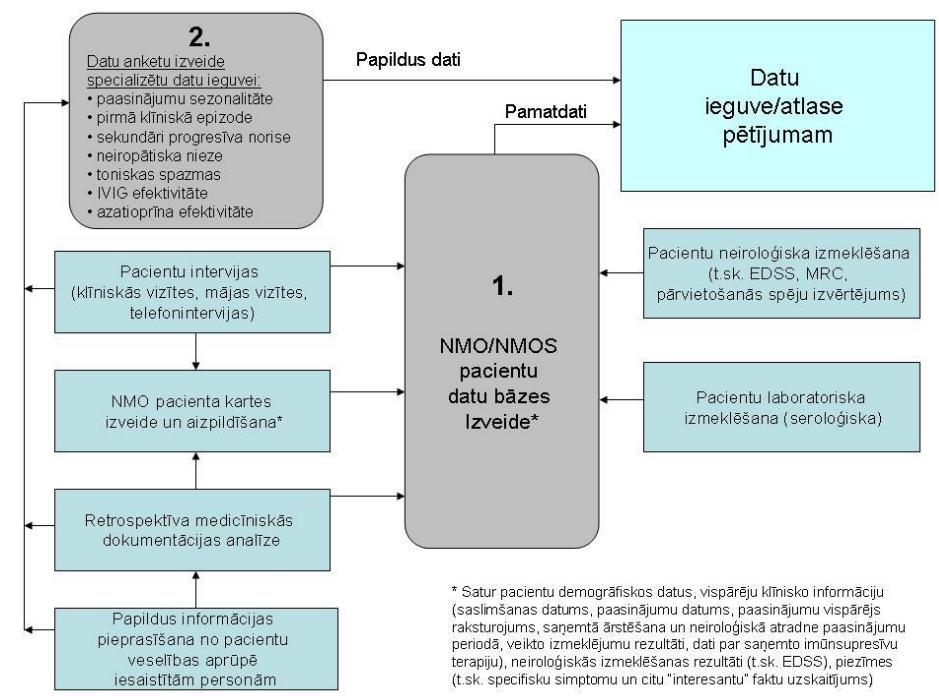

\section{2. attēls. Pētījuma datu ieguves metožu vispārējs atspoguḷojums}

\subsubsection{Neirolog̣iskā stāvokḷa novērtējums}

- EDSS izvērtējums dinamikā: 0 - $10(0$ - nav invaliditātes pazīmju, 10 - exitus letalis)

- $\quad$ muskuļu spēka izvērtējums dinamikā pēc MRC klasifikācijas: 0 - 5 (5 - normāls muskuļu spēks, 0 - pilnīga pleǵija)

\subsection{3. Ārstēšanas efektivitātes izvērtējums}

Ārstēšanas efektivitāte izvērtēta, ņemot vērā parametrus/rādītājus, kas izmantoti citos NMO pētījumos: vidējais recidīvu skaits gadā jeb RSG pirms un pēc ārstēšanas uzsākšanas (kopējais paasinājumu skaits slimības laikā izdalīts ar slimības ilgumu gados, slimnieku skaits (\%), kas sasnieguši slimības remisiju, laika intervāls no ārstēšanas uzsākšanas brīža līdz nākamajam 
recidīvam, neiroloǵiskā stāvokḷa izmaiņas (t. sk. EDSS dinamikā - uzsākot ārstēšanu un pēdējā novērošanas vizītē jeb ārstēšanas beigās), ārstēšanu pārtraukušo slimnieku skaits (\%).

\subsubsection{Diagnostiskie kritēriji}

\subsubsection{NMO diagnostiskie kritēriji}

Pacientu atlasei un sistematizācijai izmantoti starptautiskā praksē vispārpieņemtie NMO / NMOS diagnostiskie kritēriji, kas izstrādāti Maijo klīnikā (ASV) 2006. gadā (Wingerchuk, Lennon et al. 2006). Šie kritēriji attiecas uz visām darba nodal̦ām.

Obligātie nosacījumi:

- anamnēzes dati par redzes nerva neirītu;

- anamnēzes dati par mielītu;

- vismaz 2 no 3 apstiprinošie kritēriji:

- longitudināls spināls perēklis $M R$ izmeklējumā $\geq 3$ vertebrālo segmentu garumā;

- atradne galvas smadzenuu MR neatbilst MS diagnostiskiem kritērijiem;

pozitīvas NMO-IgG antivielas (jeb AQP4-IgG) serumā.

Kritēriji NMO spektra apstiprināšanai: redzes nerva neirīts vai longitudināls mielīts un pozitīvas akvaporīna 4 antivielas.

Aizdomu NMO / NMOS: idiopātisks monofāzisks vai recidivējošs redzes nerva neirīts, smadzeņu stumbra bojājums vai mielīts, kas neatbilst NMO vai MS diagnostiskiem kritērijiem.

\subsubsection{SPNMO kritēriji}

Par sekundāri progresīvu NMO norisi līdz šim ir tikai viens ziņojums. (Wingerchuk, Pittock et al. 2007). Iepriekšējā ziņojumā pielietotie SPNMO kritēriji pielietoti arī šajā darbā un ir sekojoši:

Pakāpeniska nepārtraukta stāvokḷa pasliktināšanās (vizuālā, motorā vai sensorā funkcija) > 6 mēnešus ilgi un vismaz 1 no sekojošiem rādītājiem, kas apstiprina progresiju:

1) redzes asuma samazinājums par $\geq 2$ punktiem (0 - normāls, 7 - pilnīgs aklums; skat. 11.5. un 11.6. pielikumu); 
2) muskuḷu spēka samazinājums $\geq 1$ loceklī par 2 punktiem $(0$ - pleg̣ija, 5 - normāls), izvērtējot pēc MRC skalas (skat. 11.3. pielikumu) $\geq 2$ antigravitātes muskuḷos (augšèjā ekstremitāte: deltveida, tricepss, pirkstu atliecēji, apakšējā ekstremitātē: augšstilba saliecējs, augšstilba mugurējie muskuḷi, pēdas dorsālie saliecēji);

3) EDSS pieaugums par $\geq 2$ punktiem, salīdzinot ar pēdējo stabilo izvērtējumu pirms progresijas.

\subsubsection{Pētījumā izmantotās definīijas}

- Paasinājums (recidīvs) - klīniskā epizode, kurai raksturīga simptomu akūta attīstība vai iepriekšējo simptomu pasliktināšanās, kas ilgst vismaz

24 stundas bez aktīvas infekcijas vai drudža pazīmēm ar vismaz 1 mēneša intervālu starp epizodēm, un ko apstiprinājis neirologs. Epizodes, kas attīstījās ar mazāk nekā 30 dienu starplaiku, vērtētas kā viens paasinājums.

- Pirmā klīniskā epizode jeb pirmais paasinājums (PKE) - pirmreizējs redzes nervu, smadzeñu stumbra vai muguras smadzeņu bojājumu raksturojošs simptomu komplekss, kas ilgts vismaz 24 stundas un ko apstiprinājis neirologs. Tādi izolēti nespecifiski simptomi kā slikta dūša, reibonis vai vemšana, nesekojot citām pavadošām NMO raksturīgām klīniskām pazīmēm tuvāko dienu vai nedēḷu laikā, netika vērtēti kā saslimšanas sākums.

- Klīniska remisija - laika posms starp recidīviem, kurā neiroloǵiskā stāvokḷa pasliktināšanās nav novērojama (izņemot gadījumus, kad neirologiiskā stāvokḷa pasliktināšanās saistīta ar infekcijas un / vai drudža klātbūtni u. tml.).

- Pakāpeniski jeb lēni noritošs NMO / NMOS saslimšanas sākums pirmā paasinājuma simptomu attīstības laika periods, kas ilgst vismaz 1 mēnesi (4 nedēlas jeb 28 dienas).

- Pēdējais paasinājums pirms SP norises sākuma - pēdējais (akūts vai subakūts - dažu nedēļu laikā) iepriekšējo simptomu nozīmīgs pieaugums vai jaunu simptomu attīstība nesaistīti ar steroīdu devas samazināšanu vai nesenu infekciju. 
- SP norises sākums - retrospektīvi noteikts laika punkts, kad saistīti vai nesaistīti ar pēdējo klīnisko paasinājumu, neskatoties uz saņemto ārstēšanu, novērota pakāpeniski progresējoša neirologiskā stāvokḷa pasliktināšanās, kas turpinās atbilstoši SPNMO kritērijiem.

- Medikamenta lietošanas ilgums - laika periods, kurā pacients turpina saņemt medikamentu un atspoguḷo tā efektivitāti un panesamību.

\subsubsection{Laboratoriskie testi}

Asins paraugi akvaporīna-4 (AQP4-IgG) un anti-MOG (MOG-IgG) antivielu noteikšanai ņemti VNNC kārtējo klīnisko viz̄šu apmeklējumu laikā un analizēti Oksfordas Radklifes slimnīcā neiroimunoloǵijas laboratorijā, izmantojot metodi, kas ir ar augstāko specifitāti un sensitivitāti jeb imūnfluorescences metodi (CBA) pēc iepriekš aprakstītas metodikas (Waters and Vincent 2008, Kitley, Woodhall et al. 2012, Woodhall, Coban et al. 2013, Kitley, Waters et al. 2014).

AQP4-IgG noteiktas visiem Liverpūles NMO / NMOS pacientu datu bāzē reg̣istrētajiem slimniekiem.

MOG-IgG noteiktas tikai AQP4-IgG negatīviem pacientiem, kas apmeklēja VCNN klīnisko pieņemšanu laika periodā no 2012. gada janvāra līdz 2014. gada maijam. MOG-IgG noteiktas 98 slimniekiem: 21 no 24 datu bāzē reǵistrētiem AQP4-IgG negatīviem NMO pacientiem, 77 pacientiem ar aizdomu NMOS saslimšana (AQP4-IgG negatīvs monofāzisks vai recidivējošs redzes nerva neirīts, mielīts, smadzeņu stumbra bojājums vai optikospinālas demielinizācijas sindroms, kas neatbilst NMO vai MS diagnostiskiem kritērijiem). Visi MOG-IgG pozitīvi gadījumi (NMO, redzes nerva neirīts, mielīts, smadzeņu stumbra bojājums) tika testēti atkārtoti, pielietojot modificētu analīžu metodiku, respektīvi, nosakot MOG-IgG1 subtipu. Gala rezultātā tikai gadījumi ar pozitīvu MOG-IgG1 tika vērtēti kā pozitīvi.

\subsubsection{Statistiskā apstrāde}

Pētījuma datu apstrāde un statistiskā analīze veikta pēc vispārējām medicīniskās statistikas metodēm, izmantojot aprakstošo un analītisko statistiku.

Visi paasinājumi tika kategorizēti pa grupām atkarībā no to reǵistrēšanas datuma precizitātes (precizitāte pa dienām, nedẹ̄̂ām, mēnešiem, gadiem, 
dekādes). Tikai epizodes ar precizitāti 0-30 dienas iekḷautas pētījumā. Paasinājumi, kas attīstījās ar mazāk nekā 30 dienu starplaiku, vērtētas kā viena kopīga epizode. Grupu raksturošanai tika pielietotas aprakstošās statistikas metodes. Atkarībā no main̄̄gā lieluma veida tika aprēķināti centrālās tendences rādītāji: mediānais lielums (median) vai vidējais aritmētiskais (mean), mazākā (min) un lielākā (max) aritmētiskā vērtība. Vairums pētījuma datu ir izteikti asimetriski un normālam sadalījumam neatbilstoši, tādēḷ par grupas centrālās tendences rādītāju pārsvarā izmantota mediāna (median), izkliedi atspogulojot kā mazākā un lielākā aritmētiskā vērtība vai atsevišķos gadījumos kā iekšējo kvartilu diapazons - IQR (interquartile range) jeb intervāls starp sadalījuma 25. un 75. percentili (1. un 3. kvartili). Savukārt, kā centrālās tendences rādītāju nosakot vidējo aritmētisko, norādīta izkliede vienas standartnovirzes (SD) apmērā. Pazīmes relatīvā izteiktība noteikta, pazīmes vērtību summu izdalot ar pazīmes biežumu (gadījumu skaitu), un izteikta procentuāli. Salīdzināšanai vienas grupas ietvaros (piemēram, paasinājumu biežumu gadā un EDSS pakāpi pirms un pēc ārstēšanas) izmantots Vilkoksona tests (Wilcoxon matched-pairs signed rank test), bet salīdzināšanai starp divām neatkarīgām izlasēm Manna-Vitnija (Mann-Whitney) U tests. Lai spriestu par varbūtību, ka pacienti turpinās saņemt medikamentu (AZA) laika gaitā, izmantota Kaplana-Maijera analīze. Salīdzinot starp multipliem parametriem, korekcijas netika veiktas. Mirušie pacienti vērtēti kā galamērķi nesasnieguši (right censored). Dublikāta gadījumi analīzē netika iekḷauti. Savukārt, veicot statistiskos aprēķinus, lai noskaidrotu paasinājumu sezonalitātes tendences, statistiskā apstrāde veikta 2 dal̦ās, izmantojot $\mathrm{R}$ versiju 2.14.1. Pirmkārt, dati analizēti, izmantojot vienkāršotu analīzi (sadalot kopējo paasinājumu skaitu ar 12 jeb mēnešu skaitu gadā), kā arī Puasona regresiju (koriǵējot pēc mēnešu garuma), kas noteica kopējā paasinājumu skaita variācijas pa mēnešiem. Pēc tam veikta papildu analīze par paasinājumiem, kas fiksēti laika posmā no 2002. gada 1. janvāra līdz 2011. gada 31. decembrim. Pētījuma noslēgumā, izmantojot log̣istisko regresiju, noteiktas asociācijas starp paasinājumu risku katrā gada mēnesī atsevišķi (koriǵējot pēc saslimšanas vecuma un slimības ilguma). Pētījumā par statistiski ticamām pieņemtas $\mathrm{p}$ vērtības, kas ir mazākas par 0,05, t. i., $\mathrm{p}<0,0$. 
Pētījumā izmantotās metodikas kopsavilkums

\begin{tabular}{|c|c|c|c|c|}
\hline $\begin{array}{c}\text { Pētījuma } \\
\text { nosaukums } \\
\text { un veids }\end{array}$ & $\begin{array}{c}\text { Pētāmo cilvēku grupa un } \\
\text { tās lielums }\end{array}$ & $\begin{array}{l}\text { Analizējamie } \\
\text { parametri }\end{array}$ & Metodes & Statistiskās analīzes metodes \\
\hline $\begin{array}{l}\text { Paasinājumu } \\
\text { sezonalitāte } \\
\text { Retrospektīvs, } \\
\text { aprakstošs } \\
\text { novērošanas } \\
\text { pētījums ar } \\
\text { vēsturisko } \\
\text { kontroles } \\
\text { grupu }\end{array}$ & $\begin{array}{l}\text { 165 AQP4-IgG pozitīvi } \\
\text { NMO / NMOS pacienti, } \\
\text { kas pastāvīgi novēroti } \\
\text { un reǵistrēti NMO datu } \\
\text { bāzē kādā no centriem } \\
\text { (VNNC, RS, VUS) laika } \\
\text { posmā no 2010. gada 1. } \\
\text { jūnijam līdz 2012. gada } \\
\text { 31. martam }\end{array}$ & $\begin{array}{l}\text { Demogrāfiskie dati, } \\
\text { visi klīniskie } \\
\text { paasinājumi pēc to } \\
\text { datuma (pa } \\
\text { mēnešiem). } \\
\text { Analīzē iekḷauti tikai } \\
\text { paasinājumi ar vismaz } \\
1 \text { mēneša (0-30 } \\
\text { dienas) precizitāti }\end{array}$ & $\begin{array}{l}\text { Datu anketas un datu bāzes } \\
\text { izveide; sistematizēta } \\
\text { medicīnisko dokumentu } \\
\text { analīze, nestrukturizētas } \\
\text { pacientu intervijas (kārtējās } \\
\text { pieñemšanas laikā, mājas } \\
\text { vizītes, telefonintervijas); datu } \\
\text { salīdzināšana un kvalitatīva } \\
\text { pārbaude; } \\
\text { dublikātu izslēgšana }\end{array}$ & $\begin{array}{l}\text { R versija 2.14.1; vienkāršota analīze } \\
\text { (sadalot kopējo paasinājumu skaitu ar } 12 \\
\text { jeb mēnešu skaitu gadā; Puasona regresija } \\
\text { (koriǵējot pēc mēnešu garuma), kas } \\
\text { noteica kopējā paasinājumu skaita } \\
\text { variācijas pa mēnešiem; papildu analīze } \\
\text { par paasinājumiem, kas fiksēti tikai laika } \\
\text { posmā no 2002. gada 1. janvāra līdz } 2011 . \\
\text { gada 31. decembrim; loğistiskā regresija } \\
\text { (nosakot asociācijas starp paasinājumu } \\
\text { risku katrā gada mēnes̄i atsevišķi un } \\
\text { koriğējot pēc saslimšanas vecuma un } \\
\text { slimības ilguma); vispārējās aprakstošās } \\
\text { statistikas metodes }\end{array}$ \\
\hline $\begin{array}{l}\text { Pirmās } \\
\text { klīniskās } \\
\text { epizodes } \\
\text { ipatnības }\end{array}$ & $\begin{array}{l}\text { Visi }(\mathrm{n}=123) \mathrm{NMO} / \\
\text { NMOS slimnieki, kas } \\
\text { reǵistrēti VNNC datu } \\
\text { bāzē laika posmā līdz } \\
\text { 2014. gada 1. augustam }\end{array}$ & $\begin{array}{l}\text { Demogrāfiskie dati, } \\
\text { PKE simptomu } \\
\text { raksturojums, t. sk. } \\
\text { laika intervāls līdz } \\
\text { simptomu } \\
\text { kulminācijai, }\end{array}$ & $\begin{array}{l}\text { Datu anketas un datu bāzes } \\
\text { izveide; sistematizēta } \\
\text { medicīnisko dokumentu } \\
\text { analīze, nestrukturizētas } \\
\text { pacientu intervijas (kārtējās }\end{array}$ & $\begin{array}{l}\text { Vispārējās aprakstošās statistiskās } \\
\text { metodes; grupas centrālā tendence } \\
\text { atspogul̦ota kā mediāna (median), un } \\
\text { izkliede atspoguḷota kā mazākā un lielākā } \\
\text { aritmētiskā vērtība }\end{array}$ \\
\hline
\end{tabular}


1.1. tabulas turpinājums

\begin{tabular}{|c|c|c|c|c|}
\hline $\begin{array}{c}\text { Pētījuma } \\
\text { nosaukums } \\
\text { un veids }\end{array}$ & $\begin{array}{c}\text { Pētāmo cilvēku grupa un } \\
\text { tās lielums }\end{array}$ & $\begin{array}{l}\text { Analizējamie } \\
\text { parametri }\end{array}$ & Metodes & Statistiskās analīzes metodes \\
\hline $\begin{array}{l}\text { Retrospektīvs, } \\
\text { aprakstošs } \\
\text { novērošanas } \\
\text { pētījums ar } \\
\text { vēsturisko } \\
\text { kontroles } \\
\text { grupu }\end{array}$ & & $\begin{array}{l}\text { neirologiskā deficīta } \\
\text { pakāpe simptomu } \\
\text { kulminācijas laikāa un } \\
\text { pēc ārstēšanas, } \\
\text { saņemtā ārstēšana; MR } \\
\text { atradne }\end{array}$ & $\begin{array}{l}\text { pieñemšanas laikā, mājas } \\
\text { vizìtes, telefonintervijas); } \\
\text { neiroloğiskā izmeklēšana } \\
\text { (EDSS), datu salīdzināšana un } \\
\text { kvalitatīva pārbaude }\end{array}$ & \\
\hline $\begin{array}{l}\text { Neiropātiska } \\
\text { nieze } \\
\text { Retrospektīvs, } \\
\text { aprakstošs } \\
\text { novērošanas } \\
\text { pētījums ar } \\
\text { vēsturisko } \\
\text { kontroles } \\
\text { grupu }\end{array}$ & $\begin{array}{l}\text { Visi (n = 44) AQP4-IgG } \\
\text { pozitīvi NMO / NMOS } \\
\text { slimnieki, kas apmeklēja } \\
\text { VNNC laika posmā no } \\
\text { 2011. gada 1. janvāra } \\
\text { līdz 2012. gada 1. } \\
\text { martam, anamnēzē } \\
\text { konstatēts mielīts / } \\
\text { sm. st. boj. }\end{array}$ & $\begin{array}{l}\text { Demogrāfiskie dati, } \\
\text { slimības vispārējs } \\
\text { raksturojums, t.sk. } \\
\text { paasinājumu } \\
\text { raksturojums, MR } \\
\text { atradne; niezes } \\
\text { raksturojums; niezes } \\
\text { saistība ar neirologisko } \\
\text { atradni un MR } \\
\text { izmeklējumu } \\
\text { rezultātiem }\end{array}$ & $\begin{array}{l}\text { Datu anketas un datu bāzes } \\
\text { izveide; sistematizēta } \\
\text { medicīnisko dokumentu } \\
\text { analīze, strukturizētas pacientu } \\
\text { intervijas pēc iepriekš } \\
\text { izveidotas anketas (kārtējās } \\
\text { pieñemšanas laikāa, mājas } \\
\text { vizītes, telefonintervijas); } \\
\text { numeroloğiska niezes } \\
\text { intensitātes izvērtēšana pēc } \\
\text { sāpju skalas } \\
\text { (0-0); neirologiiskā } \\
\text { izmeklěšana (EDSS), datu } \\
\text { salīdzināšana un kvalitatīva } \\
\text { pārbaude }\end{array}$ & $\begin{array}{l}\text { Vispārējās aprakstošās statistiskās } \\
\text { metodes; grupas centrālā tendence } \\
\text { atspoguḷota kā mediāna (median), un } \\
\text { izkliede atspoguḷota kā mazākā un lielākā } \\
\text { aritmētiskā vērtība }\end{array}$ \\
\hline
\end{tabular}


1.1. tabulas turpinājums

\begin{tabular}{|c|c|c|c|c|}
\hline $\begin{array}{c}\text { Pētījuma } \\
\text { nosaukums un } \\
\text { veids }\end{array}$ & $\begin{array}{c}\text { Pētāmo cilvēku grupa } \\
\text { un tās lielums }\end{array}$ & $\begin{array}{l}\text { Analizējamie } \\
\text { parametri }\end{array}$ & Metodes & Statistiskās analīzes metodes \\
\hline $\begin{array}{l}\text { Toniskas } \\
\text { spazmas }\end{array}$ & $\begin{array}{l}\text { Visi }(\mathrm{n}=44) \mathrm{AQP} 4-\mathrm{IgG} \\
\text { pozitīvi NMO/NMOS } \\
\text { slimnieki, kas apmeklēja } \\
\text { laika posmā no 2011. } \\
\text { gada 1. janvāra līdz } \\
\text { 2012. gada 1. martam, } \\
\text { anamnēzē konstatēts } \\
\text { mielīts / sm.st.boj. }\end{array}$ & $\begin{array}{l}\text { Demogrāfiskie dati, } \\
\text { slimības vispārējs } \\
\text { raksturojums, t.sk. } \\
\text { paasinājumu } \\
\text { raksturojums, MR } \\
\text { atradne; tonisku spazmu } \\
\text { raksturojums; tonisku } \\
\text { spazmu saistība ar } \\
\text { neirologisko atradni un } \\
\text { MR izmeklējumu } \\
\text { rezultātiem }\end{array}$ & $\begin{array}{l}\text { Datu anketas un datu bāzes } \\
\text { izveide; sistematizēta } \\
\text { medicīnisko dokumentu analīze, } \\
\text { strukturizētas pacientu intervijas } \\
\text { (kārtējās pieņemšanas laikā, } \\
\text { mājas vizītes, telefonintervijas) } \\
\text { pēc iepriekš izveidotas anketas; } \\
\text { neirologiskā izmeklēšana } \\
\text { (EDSS), datu salīdzināšana un } \\
\text { kvalitatīva pārbaude }\end{array}$ & $\begin{array}{l}\text { Vispārējās aprakstošās statistiskās metodes; } \\
\text { grupas centrālā tendence atspoguḷota kāa } \\
\text { mediāna (median), un izkliede atspoguḷota } \\
\text { kā mazākā un lielākā aritmētiskā vērtība }\end{array}$ \\
\hline $\begin{array}{l}\begin{array}{l}\text { Sekundāri } \\
\text { progresējoša } \\
\text { norise }\end{array} \\
\text { Retrospektīvs, } \\
\text { aprakstošs } \\
\text { novērošanas } \\
\text { pētījums ar } \\
\text { vēsturisko } \\
\text { kontroles } \\
\text { grupu }\end{array}$ & $\begin{array}{l}\text { Visi }(\mathrm{n}=123) \mathrm{NMO} / \\
\text { NMOS slimnieki, kas } \\
\text { reǵistrēti VNNC datu } \\
\text { bāzē laika posmā līdz } \\
\text { 2014. gada } \\
\text { 1. augustam }\end{array}$ & $\begin{array}{l}\text { Demogrāfiskie dati, } \\
\text { slimības vispārējs } \\
\text { raksturojums, MR } \\
\text { atradne, saṇemtā } \\
\text { ārstēšana, SP norises } \\
\text { raksturojums, } \\
\text { neiroloğisko } \\
\text { traucējumu } \\
\text { atspogul̦ojums } \\
\text { dinamikā, t. sk. EDSS, } \\
\text { muskuḷu spēks (MRC) }\end{array}$ & $\begin{array}{l}\text { Datu anketas un datu bāzes } \\
\text { izveide; sistematizēta } \\
\text { medic̄̄nisko dokumentu } \\
\text { analīze, strukturizētas pacientu } \\
\text { intervijas (kārtējās pieņemšanas } \\
\text { laikā, mājas vizītes, } \\
\text { telefonintervijas) pēc iepriekš } \\
\text { izveidotas anketas, neirologisiskā } \\
\text { izmeklēšana (EDSS, MRC } \\
\text { skala, ambulatorais indekss), } \\
\text { datu salīdzināšana un } \\
\text { kvalitatīva pārbaude; pacientu } \\
\text { izvērtěšana atbilstoši SPNMO } \\
\text { kritērijiem }\end{array}$ & $\begin{array}{l}\text { Vispārējās aprakstošās statistiskās } \\
\text { metodes; grupas centrālā tendence } \\
\text { atspoguḷota kā vidējais aritmētiskais } \\
\text { (mean), un izkliede atspoguḷota vienas } \\
\text { standartnovirzes diapazonā }\end{array}$ \\
\hline
\end{tabular}


1.1. tabulas turpinājums

\begin{tabular}{|c|c|c|c|c|}
\hline $\begin{array}{c}\text { Pētījuma } \\
\text { nosaukums un } \\
\text { veids }\end{array}$ & $\begin{array}{c}\text { Pētāmo cilvēku grupa } \\
\text { un tās lielums }\end{array}$ & $\begin{array}{l}\text { Analizējamie } \\
\text { parametri }\end{array}$ & Metodes & Statistiskās analīzes metodes \\
\hline $\begin{array}{l}\text { MOG-IgG } \\
\text { pozitīvu } \\
\text { pacientu } \\
\text { fenotips } \\
\text { Retrospektīvs, } \\
\text { aprakstošs } \\
\text { novērošanas } \\
\text { pētījums ar } \\
\text { vēsturisko } \\
\text { kontroles grupu }\end{array}$ & $\begin{array}{l}\text { Visi }(\mathrm{n}=98) \text { AQP4-IgG } \\
\text { negatîvi NMO un / vai } \\
\text { aizdomu NMOS (ON, } \\
\text { TM vai optikospināla } \\
\text { demielinizācija, kas } \\
\text { neatbilst NMO vai MS } \\
\text { kritērijiem) slimnieki, } \\
\text { kas laika periodā līdz } \\
\text { 2014. gada maijam } \\
\text { apmeklēja VNNC un } \\
\text { kuriem tika noteikts } \\
\text { MOG-IgG (asinīs) }\end{array}$ & $\begin{array}{l}\text { Demogrāfiskie dati, } \\
\text { slimības vispārējs } \\
\text { raksturojums, t. sk. } \\
\text { paasinājumu fenotips, } \\
\text { MR atradne, } \\
\text { laboratoriskie dati, } \\
\text { saņemtā ārstēšana, } \\
\text { neirologisko traucējumu } \\
\text { atspoguḷojums }\end{array}$ & $\begin{array}{l}\text { Datu anketas un datu bāzes } \\
\text { izveide; sistematizēta } \\
\text { medicīnisko dokumentu } \\
\text { analīze, strukturizētas pacientu } \\
\text { intervijas (kārtējās pieņemšanas } \\
\text { laikā, mājas vizītes, } \\
\text { telefonintervijas) pēc iepriekš } \\
\text { izveidotas anketas, neiroloğiskā } \\
\text { izmeklěšana (EDSS); } \\
\text { laboratorisko datu skrīnings, } \\
\text { visu MOG-IgG pozitīvu } \\
\text { pacientu un AQP4-IgG } \\
\text { negatīvu NMO atkārtota } \\
\text { testēšana, nosakot MOG-IgG1 } \\
\text { subtipu; EDSS skala } \\
\text { neirologiskā deficīta } \\
\text { noteikšanai; datu salīdzināšana } \\
\text { un kvalitatīva pārbaude }\end{array}$ & $\begin{array}{l}\text { Vispārējās aprakstošās statistiskās metodes; } \\
\text { grupas centrālā tendence atspogulota kā } \\
\text { mediāna (median), un izkliede atspogulota } \\
\text { kā mazākā un lielākā aritmētiskā vērtība }\end{array}$ \\
\hline
\end{tabular}


1.1. tabulas turpinājums

\begin{tabular}{|c|c|c|c|c|}
\hline $\begin{array}{c}\text { Pētījuma } \\
\text { nosaukums un } \\
\text { veids }\end{array}$ & $\begin{array}{l}\text { Pētāmo cilvēku grupa } \\
\text { un tās lielums }\end{array}$ & $\begin{array}{l}\text { Analizējamie } \\
\text { parametri }\end{array}$ & Metodes & Statistiskās analīzes metodes \\
\hline $\begin{array}{l}\text { Ārstēšana ar } \\
\text { IVIG } \\
\text { Retrospektīvs } \\
\text { aprakstošs } \\
\text { novērošanas } \\
\text { pētījums }\end{array}$ & $\begin{array}{l}\text { Visi (n = 93) NMO / } \\
\text { NMOS slimnieki, kas } \\
\text { ārstējušies VNNC } \\
\text { laika periodā no } 2003 . \\
\text { gada augusta līdz } \\
\text { 2012. gada 1. } \\
\text { decembrim }\end{array}$ & $\begin{array}{l}\text { Demogrāfiskie dati, } \\
\text { slimības raksturojums, } \\
\text { neirologisko } \\
\text { traucējumu } \\
\text { atspogulojums } \\
\text { dinamikā, (EDSS), } \\
\text { IVIG efektivitātes un } \\
\text { panesamības } \\
\text { izvērtējums }\end{array}$ & $\begin{array}{l}\text { Datu anketas un datu bāzes } \\
\text { izveide; sistematizēta } \\
\text { medicīnisko dokumentu analīze, } \\
\text { strukturizētas pacientu intervijas } \\
\text { (kārtējās pienememšanas laikā, } \\
\text { mājas vizītes, telefonintervijas) } \\
\text { pēc iepriekš izveidotas anketas, } \\
\text { neirologisiskā izmeklēšana } \\
\text { (EDSS), datu salīdzināšana un } \\
\text { kvalitatīva pārbaude }\end{array}$ & $\begin{array}{l}\text { Vispāāejās aprakstošās statistiskās } \\
\text { metodes; grupas centrālā tendence } \\
\text { atspoguḷota kā mediāna (median), un } \\
\text { izkliede atspoguḷota kā mazākā un lielākā } \\
\text { aritmētiskā vērtība }\end{array}$ \\
\hline $\begin{array}{l}\text { Ārstēšana ar } \\
\text { azatioprīnu } \\
\text { Retrospektīvs, } \\
\text { aprakstošs } \\
\text { novērošanas } \\
\text { pētījums ar } \\
\text { vēsturisko } \\
\text { kontroles grupu }\end{array}$ & $\begin{array}{l}\text { Visi (n=103) } \\
\text { NMO/NMOS } \\
\text { slimnieki, kas } \\
\text { ārstējušies kādā no } 4 \\
\text { centriem (VNNC, RS, } \\
\text { VUS, BUS) un } \\
\text { slimības periodā (līedz } \\
\text { 2013. gada maijam) } \\
\text { saṇēmuši AZA; }\end{array}$ & $\begin{array}{l}\text { Demogrāfiskie dati, } \\
\text { slimības vispārējs } \\
\text { raksturojums, } \\
\text { neiroloğisko traucējumu } \\
\text { atspogulojums } \\
\text { dinamikā, (EDSS), } \\
\text { AZA efektivitātes, } \\
\text { lietošanas ilguma un } \\
\text { panesamības } \\
\text { izvērtējums }\end{array}$ & $\begin{array}{l}\text { Datu anketas un datu bāzes } \\
\text { izveide; sistematizēta } \\
\text { medicīnisko dokumentu analīze, } \\
\text { strukturizētas pacientu intervijas } \\
\text { (kārtējās pieņemšanas laikā, } \\
\text { mājas vizītes, telefonintervijas) } \\
\text { pēc iepriekš izveidotas anketas, } \\
\text { neirologisiskā izmeklēšana } \\
\text { (EDSS), datu salīdzināšana un } \\
\text { kvalitatīva pārbaude; dublikātu } \\
\text { izslēgšana }\end{array}$ & $\begin{array}{l}\text { Vispāāejāās aprakstošās un analīitiskās } \\
\text { statistiskās metodes; apakšgrupu analīze; } \\
\text { katras grupas centrālā tendence atspoguḷota } \\
\text { kā mediāna (median), un izkliede } \\
\text { atspogulota kā mazākā un lielākā } \\
\text { aritmētiskā vērtîba vai iekšējo kvartiḷu } \\
\text { diapazons (IQR); Vilkoksona ranga zīmju } \\
\text { tests (Wilcoxon Signed Ranks Test) } \\
\text { salīdzināšanai vienas grupas ietvaros, }\end{array}$ \\
\hline
\end{tabular}


1.1. tabulas turpinājums

\begin{tabular}{|c|c|c|c|c|}
\hline $\begin{array}{c}\text { Pētījuma } \\
\text { nosaukums un } \\
\text { veids }\end{array}$ & $\begin{array}{l}\text { Pētāmo cilvēku grupa } \\
\text { un tās lielums }\end{array}$ & $\begin{array}{c}\text { Analizējamie } \\
\text { parametri }\end{array}$ & Metodes & Statistiskās analīzes metodes \\
\hline & $\begin{array}{l}72 \text { slimnieki ar } \\
\text { novērošanas ilgumu } \geq 6 \\
\text { mēneši, } 36 \text { slimnieki ar } \\
\geq 2 \text { paasinājumiem } \\
\text { pēdējo } 6 \text { mēnešu vai } \geq 3 \\
\text { paasinājumiem pēdējo } \\
12 \text { mēnešu laikā } \\
\text { (ANMO), } 62 \text { slimnieki } \\
\text { ar izteiktu funkciju } \\
\text { deficītu (SNNMO) jeb } \\
\text { EDSS } \geq 6 \text { mielīta } \\
\text { gadījumā un EDSS } \geq 3 \\
\text { (vizuālā skala } \geq 4 \text { ar } \\
\text { maksimālo redzes } \\
\text { asumu } 6 / 36-6 / 60 \\
\text { sliktākajā acī) ON }\end{array}$ & & & $\begin{array}{l}\text { Manna-Vitnija (Mann-Whitney) U tests - } \\
\text { salīdzināšanai starp divām neatkarīgām } \\
\text { izlasēm; Kaplana-Maijera analīze. Mirušie } \\
\text { pacienti vērtēti kā gala punktu } \\
\text { nesasnieguši (right censored). }\end{array}$ \\
\hline $\begin{array}{l}\text { Latvijas } M S \\
\text { registrā } \\
\text { ievadāmo datu } \\
\text { analīze }\end{array}$ & $\begin{array}{l}\text { Latvijas MS pacienta } \\
\text { karte (Ministru Kabineta } \\
\text { 2008. gada 15. } \\
\text { septembra noteikumi } \\
\text { Nr. 746; 13. pielikums) }\end{array}$ & 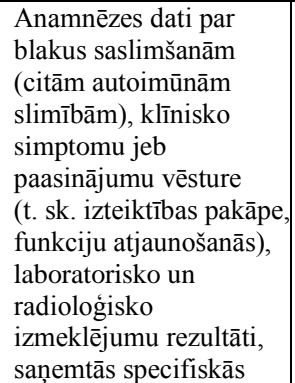 & $\begin{array}{l}\text { Latvijas MS pacienta kartes datu } \\
\text { kvalitatīva un kvantitatīva } \\
\text { analīze; MS reğistra potenciālās } \\
\text { lomas izvērtēšana retrospektīvai } \\
\text { NMO / NMOS gadījumu } \\
\text { atklāšanai; reǵistra } \\
\text { funkcionalitātes salīdzinājums ar } \\
\text { literatūras datiem par vadošajiem } \\
\text { DS/MS reǵistriem }\end{array}$ & Vispārējās aprakstošās statistikas metodes \\
\hline
\end{tabular}




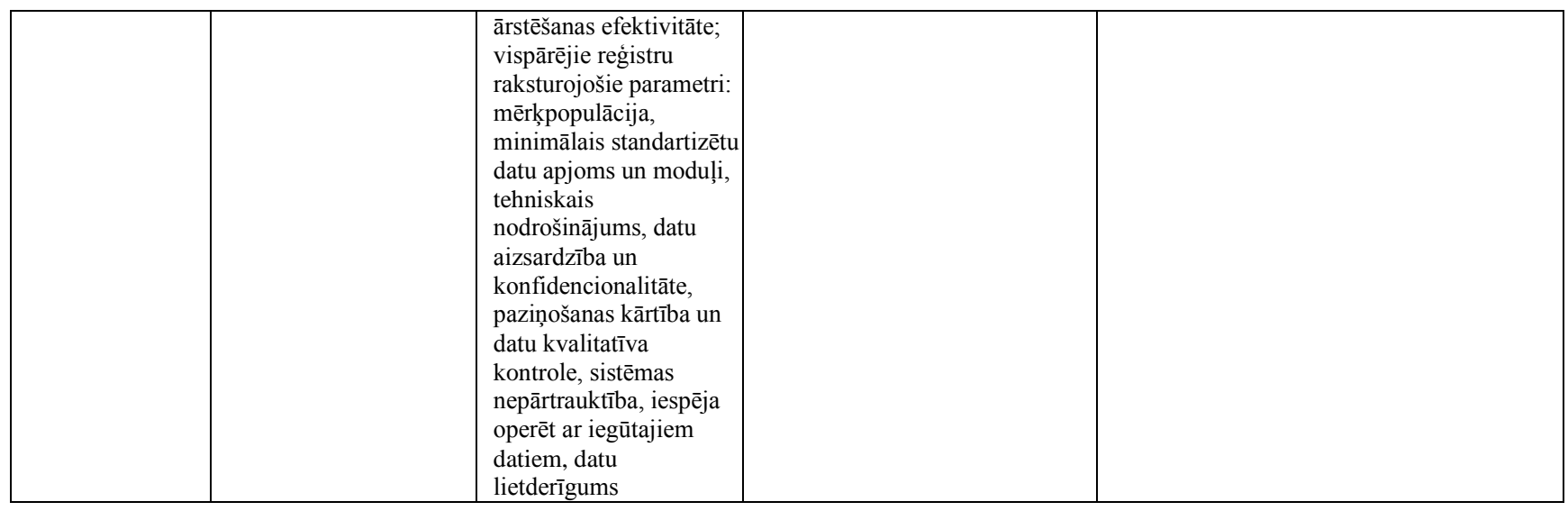

VNNC - Valtonas centrs, RS - Džona Radklifes slimnīca, VUS - Velsas Universitātes slimnīca, BUS - Birmingemas universitātes slimnīca, ANMO optiskais neiromielīits ar izteiktāku slimības aktivitāti,, SPNMO - sekundāri progresīvs optiskais neiromielīts, AZA - azatioprīns, EDSS - izvērsta invaliditātes statusa skala, IVIG - intravenozi imūnglobulīni, MRC - medicīnas zinātniskās padomes vērtējuma sistēma (medical research council grading system), MOG-IgG - antivielas pret mielīna oligodendrocītu proteīnu, PKE - pirmā klīniskā epizode 


\section{REZULTĀTI}

\subsection{Optiskā neiromielīta klīniskais raksturojums}

\subsubsection{Paasinājumu sezonalitāte}

Kopā 3 centros atlasīti un sākotnēji analizēti dati par 165 AQP4-IgG pozitīviem NMO/NMOS pacientiem. Pēc dublikātu, kā arī pacientu ar neprecīzu paasinājumu vēsturi (piemēram, zināmi dati tikai par pirmo klīnisko epizodi) izslēgšanas, turpmāk aplūkoti un padziļināti analizēti dati par 150 pacientiem: $130(86,7 \%)$ sievietes un $20(13,3 \%)$ vīrieši. Slimnieku vidējais vecums (SD) saslimšanas sākumā bija 41,3 $( \pm 17,12)$, bet vidējais slimības ilgums - 8,6 (0,3-37) gadi. Šajā periodā reǵistrēti 772 paasinājumi, mediāni 4 $(1-28)$ uz vienu pacientu; vidējais recidīivu skaits gadā (RSG) - 0,59. 11\% (17/150) pacientu novēroja tikai vienu slimības recidīvu, savukārt 77\% $(115 / 150)$ - reǵistrēti 3 un vairāk paasinājumu.

Precīzs simptomu attīstības sākums (kā minimums līdz mēneša precizitātei) nebija zināms 80 (10\%) recidīviem, tādēl aprēķinos iekḷauti 692 no 772 (150 pacienti). Vienkāršotā analīzē jeb kopējo paasinājumu skaitu (100\%) izdalot ar 12 (mēnešu skaitu gadā), vidējais paredzamais paasinājumu skaits mēnesī būtu 57,6 (8,33\%). Reālais kopējais paasinājumu skaits svārstās no 46 jeb 6,6\% (jūnijā) līdz 69 jeb 9,8\% (janvārī), un gada griezumā sadalījums pa mēnešiem bija samērā vienmērīgs. Būtiskas atškirīibas starp abiem dzimumiem, kā arī, analizējot datus tikai par pirmo paasinājumu, nebija novērojamas. Puasona regresijas rezultāti (koriǵējot pēc mēnešu garuma) bija līdzīgi, viszemāko aktivitāti uzrādot jūnijā, tomēr statistiski nozīmīgas paasinājumu skaita atšķirības, salīdzinot gada mēnešus, netika novērotas (skat. 2.1. tabulu).

Arī analizējot paasinājumus tikai par laika periodu no 2002. gada 1. janvāra līdz 2011. gada 31. decembrim, rezultāti bija līdzīgi. Lai noteiktu, vai gada mēnesis ir riska faktors paasinājumam, izmantota logistiskā regresija (koriǵējot pēc vecuma saslimšanas sākumā un slimības ilguma). 
2.1. tabula

Paasinājumu sadalījums pa mēnešiem, izmantojot vienkāršotu analīzi un Puasona regresiju

\begin{tabular}{|l|c|c|c|}
\hline \multicolumn{1}{|c|}{ Metode } & Vienkāršota analīze & \multicolumn{2}{|c|}{ Puasona regresija } \\
\hline Mēnesis & $\begin{array}{c}\text { Kopējais paasinājumu } \\
\text { sadalījums pa } \\
\text { mēnešiem (\%) }\end{array}$ & $\begin{array}{c}\text { Paasinājumu biežuma } \\
\text { proporcija jeb koeficients } \\
(95 \% \text { ticamības intervāls })\end{array}$ & p vērtība \\
\hline Janvāris & $69(9,8)$ & Atsauces mēnesis & Atsauces mēnesis \\
\hline Februāris & $54(7,8)$ & $1,05(0,70-1,59)$ & 0,81 \\
\hline Marts & $57(8,2)$ & $0,89(0,59-1,36)$ & 0,59 \\
\hline Aprīlis & $56(8,1)$ & $0,94(0,62-1,43)$ & 0,78 \\
\hline Maijs & $68(9,8)$ & $1,04(0,70-1,56)$ & 0,84 \\
\hline Jūnijs & $46(6,6)$ & $0,74(0,47-1,16)$ & 0,19 \\
\hline Jūlijs & $53(7,7)$ & $0,87(0,57-1,33)$ & 0,52 \\
\hline Augusts & $57(8,2)$ & $1,02(0,68-1,53)$ & 0,92 \\
\hline Septembris & $58(8,4)$ & $1,12(0,75-1,68)$ & 0,57 \\
\hline Oktobris & $58(8,4)$ & $1,02(0,68-1,53)$ & 0,92 \\
\hline Novembris & $59(8,5)$ & $1,06(0,70-1,59)$ & 0,79 \\
\hline Decembris & $57(8,2)$ & $1,07(0,71-1,59)$ & 0,76 \\
\hline
\end{tabular}

Šajā aprēķinā ņemti vērā gan pacienti ar lielu paasinājumu skaitu, gan pacienti ar novērošanas jeb slimības periodu, kas bija īsāks par pētījuma kopējo laika periodu (2002.-2011. gadam), tādējādi, ja to saslimšanas sākums bija tikai 2005. gadā, viṇu dati tika iekḷauti analīzē tikai par laika periodu no 2005. līdz 2011. gadam, bet ne agrāk. Šīs analīzes rezultāti norādīja uz nedaudz lielāku varbūtību, ka paasinājumi attīstīsies novembrī $(p=0,007)$ vai oktobrī ( $\mathrm{p}=0,04)$, salīdzinājumā ar janvāri (skat. 2.2. tabulu). 
Logistiskā regresija

\begin{tabular}{|l|c|c|}
\hline \multicolumn{1}{|c|}{ Mēnesis } & Rezultāti & p vērtība \\
\hline Janvāris & Atsauces mēnesis & Atsauces mēnesis \\
\hline Februāris & $1,5 \times 10^{-18}$ & 0,92 \\
\hline Marts & $2,0 \times 10^{-18}$ & 0,90 \\
\hline Aprīlis & $1,5 \times 10^{-18}$ & 0,93 \\
\hline Maijs & $2,6 \times 10^{-18}$ & 0,87 \\
\hline Jūnijs & $2,4 \times 10^{-18}$ & 0,89 \\
\hline Jūlijs & $2,1 \times 10^{-18}$ & 0,90 \\
\hline Augusts & $1,8 \times 10^{-18}$ & 0,91 \\
\hline Septembris & $3,3 \times 10^{-18}$ & 0,83 \\
\hline Oktobris & $3,3 \times 10^{-18}$ & 0,04 \\
\hline Novembris & $4,4 \times 10^{-17}$ & 0,007 \\
\hline Decembris & $1,0 \times 10^{-18}$ & 0,95 \\
\hline Slimības ilgums & $8,6 \times 10^{-19}$ & 0,06 \\
\hline Saslimšanas vecums & $-1 \times 10^{-19}$ & 0,28 \\
\hline
\end{tabular}

\subsubsection{Pirmās klīniskās epizodes īpatnības}

Pētījumam tika atlasīti 123 slimnieki, 2 no tiem klīniskā informācija attiecībā uz pirmo paasinājumu nebija pietiekama, tādēl turpmākā analīzē netika iekḷauti. Tā rezultātā - padzilināti analizēti un turpmāk atspoguļoti dati par 121/123 (98\%) slimniekiem (93 sievietes, 94 AQP4-IgG pozitīvi). Atsevišķos gadījumos nebija iespējams precizēt arī dienu skaitu līdz simptomu maksimumam, EDSS pakāpi, bojājuma precīzu lokalizāciju MR, PKE laikā saņemto ārstēšanu vai funkciju atjaunošanās pakāpi. Slimnieku mediānais saslimšanas vecums bija 40 (5-79) un slimības ilgums - 6,8 $(0,2-10,8)$ gadi. PKE izpaudās ar vienpusēju ON - 24\% ( $\mathrm{n}=29)$, abpusēju ON $-18,3 \%$ $(\mathrm{n}=10), \mathrm{TM}-49,6 \%(\mathrm{n}=60)$, vienpusēju ON un TM - 5,8\% ( $\mathrm{n}=7)$, abpusēju ON un TM - 5\% $(\mathrm{n}=6)$. Laika intervāls no simptomu sākuma līdz to 
kulminācijai PKE laikā (zināms 93 slimniekiem) bija mediāni 9 dienas: dienas laikā - 13\% ( $\mathrm{n}=12)$, dažu dienu (nesasniedzot 1 nedēlu) laikā $-27 \%(\mathrm{n}=25)$, vairāku nedēļu laikā (nesasniedzot 1 mēnesi) - 36,6\% ( $\mathrm{n}=34)$ vai vairāku mēnešu (1-18) laikā - 23,7\% ( $\mathrm{n}=22)$. Dati par AQP4-IgG negatīviem un AQP4-IgG pozitīviem pacientiem atspoguḷoti katrs atsevišķi.

\subsubsection{AQP4-IgG negativi gadījumi $(n=27)$}

AQP4-IgG negatīvu pacientu (15 sievietes, 12 vīrieši) mediānais saslimšanas vecums bija $37,92(5,08-61,33)$ un slimības ilgums - 6,58 $(0,17-26,58)$ gadi. PKE izpaudās ar vienpusēju ON - 15\% ( $\mathrm{n}=4)$, abpusēju $\mathrm{ON}-15 \%(\mathrm{n}=4), \mathrm{TM}-40,7 \%(\mathrm{n}=11)$, vienpusēju $\mathrm{ON}$ un $\mathrm{TM}-18,5 \%$ $(\mathrm{n}=5)$, abpusēju ON un TM - 11\% ( $=3)$. Laika intervāls no simptomu sākuma līdz to kulminācijai PKE laikā (zināms 19 pacientiem) bija mediāni 12,5 (1-168) dienas: dienas laikā - 5,3\% ( $\mathrm{n}=1)$, dažu dienu (nesasniedzot 1 nedēḷu) laikā - 15,8\% ( $\mathrm{n}=3)$, vairāku nedēḷu laikā (nesasniedzot 1 mēnesi) $42,1 \%(n=8)$ vai vairāku mēnešu $(1-18)$ laikā $-36,8 \%(n=7)$.

Paasinājuma simptomu kulminācijā mediānā EDSS pakāpe (zināma $74 \%$ jeb 20/27 pacientiem) bija 5,75 (1,5-8). 80\% (16/20) novēroja izteiktu funkciju deficītu (EDSS $\geq 3$ pacientiem ar ON un EDSS $\geq 6$ pacientiem ar mielītu). Terapiju paasinājuma akūtā periodā saņēma 22 pacienti: 86,4\% $(\mathrm{n}=19)$ - sterōidus, 9,1\% (n = 2) - steroīdus kombinācijā ar plazmaferēzi, 4,5\% ( $\mathrm{n}=1)$ - ciklofosfamīdu. Nozīmīgu neirologisko funkciju atjaunošanos (zināma 24/27 pacientiem) novēroja 33\% (n = 8). Pārējos gadījumos, neskatoties uz nozīmīgu funkciju uzlabošanos, saglabājās izteikts funkciju deficīts $(n=12)$ vai arī stāvokḷa uzlabošanās bija nenozīmīga $(n=4)$. Visiem pacientiem novēroja atkārtotus paasinājumus - mediāni pēc 5 (1-299) mēnešiem.

\subsubsection{AQP4-IgG pozitīvi pacienti $(n=94)$}

AQP4-IgG pozitīvu pacientu (78 sievietes, 16 vīrieši) mediānais slimības ilgums bija 6,58 $(0,5-38,3)$ un saslimšanas vecums - 40,6 $(7,2-78,6)$ gadi. Pirmais paasinājums izpaudās ar vienpusēju ON - 26,6\% (n = 25), abpusēju $\mathrm{ON}-6,4 \%(\mathrm{n}=6), \mathrm{TM}-52,1 \%(\mathrm{n}=49)$, vienpusēju ON un TM $2 \%(\mathrm{n}=2)$, abpusēju ON un TM - 3,2\% ( $=3)$, cita veida klīnisko sindromu - 
9,6\% ( $\mathrm{n}=9$ ). Līdz simptomu izteiktības maksimumam jeb kulminācijai (zināms 74 slimniekiem) bija mediāni 7 (1-126) dienas: 24 stundas $-15,7 \%$ ( $\mathrm{n}=11)$, dažas dienas, bet mazāk nekā nedēḷa - 29,7\% ( $\mathrm{n}=22), 1$ līdz 4 nedēlas $-35,1 \%(n=26)$, mēneši $(\geq 1)-20,3 \%(n=15)$. Mediānais EDSS (zināms 67/94 pacientiem) bija $4(1-8) .77,6 \%(\mathrm{n}=52)$ no šiem pacientiem novēroja izteiktus neiroloǵiskos traucējumus (EDSS $\geq 3$ pacientiem ar ON un EDSS $\geq 6$ pacientiem ar TM). Terapiju akūtā periodā saņēma 61 (65\%) pacients (steroīdus - 56, sterō̄dus kombinācijā ar plazmaferēzi - 3, plazmaferēzi - 1, citu - 1), ārstēšanu nesaņēma 23 (24,5\%), savukārt 10 gadījumos dati par ārstēšanu nebija pieejami. 15,5\% $(\mathrm{n}=14)$ slimnieku funkciju atjaunošanās pēc PKE (zināms 90/94 slimniekiem) bija nenozīmīga un 52,2\% ( $\mathrm{n}=47)$ laba. Savukārt atlikušai trešdaļai $(\mathrm{n}=29)$, neskatoties uz funkciju uzlabošanos, saglabājās nozīmīgs neirologiisks deficīts. 91,4\% (n = 86) gadījumu, mediāni pēc 8 (1-278) mēnešiem, attīstījās jauns slimības recidīvs.

\subsubsection{Pacienti ar pakāpenisku saslimšanas sākumu $(\mathbf{n}=22)$}

Dati par laika periodu līdz simptomu izteiktības maksimumam pirmās klīniskās epizodes laikā bija zināmi 93 no 121 analizētajos gadījumos. PKE simptomi savu izteiktības maksimumu sasniedza $\geq 7$ dienu laikā 60,2\% (56/93) pacientu un 39\% (22/56) no tiem subakūti jeb progresējoši - 4 un vairāk nedēlu laikā (mediāni 2,3 (1-18) mēnešos), kas sastāda 23,7\% no visiem NMO/NMOS slimniekiem. AQP4-IgG antivielas bija pozitīvas 68,2\% (15/22). Mediānais saslimšanas vecums bija $42,5 \quad(18,2-67,5)$, bet slimības ilgums - 5,38 $(0,17-28,6)$ gadi. PKE izpaudās ar: vienpusēju ON - 2, abpusēju ON - 1, TM 12, smadzeņu stumbra bojājumu - 3, vienpusēju ON un TM - 1, abpusēju ON un TM - 3 gadījumos. Ārstēšanu akūtā periodā saṇēma 19/22 slimnieki: kortikosteroīdus - 17, PLEX - 2, ciklofosfamīdu - 1. Labu funkciju atjaunošanos pēc terapijas novēroja tikai $41 \%(\mathrm{n}=9)$, savukārt $55 \%(\mathrm{n}=12)$ nebija vērojama nekāda uzlabošanās vai arī tā bija nepiln̄̄ga, bet 1 gadījumā ārstēšanas rezultāti nebija zināmi. Turpmākus slimības recidīvus novēroja 82\% (18/22) slimnieku - mediāni pēc 5 (2-299) mēnešiem. 3/4 slimnieku ar monofāzisku slimības norisi slimības ilgums nepārsniedza 1 gadu, bet 1 atlikušajā gadījumā tas bija 5,1 gadi. 


\subsubsection{Sekundāri progresīva norise}

Pētījumā analizēti dati par 123 slimniekiem (95 sievietes un 96 AQP4IgG pozitīvi). To mediānais saslimšanas vecums bija 40 (5-79) un slimības ilgums 6,8 (0,2-38,3) gadi. No visiem analizētajiem slimniekiem 5/123 atbilda SPNMO kritērijiem (skat. 2.3. tabulu), kas sastāda 4\% no visiem NMO / NMOS gadījumiem. Atradne galvas smadzeņu sākotnējā MR izmeklējumā bija normāla visos, izņemot 1 gadījumā, kurā konstatēja nespecifiskas baltās vielas izmaiņas. Visi pacienti bija saņēmuši imūnsupresīvu terapiju: azatioprīnu - 4, prednizolonu - 3, metotreksātu - 2, IVIG - 1. Slimnieku detalizētu aprakstu skat promocijas darba pilnajā versijā. 
SPNMO slimnieku demogrāfiskie rādītāji un vispārējs raksturojums

\begin{tabular}{|c|c|c|c|c|c|c|c|c|c|}
\hline $\begin{array}{l}\text { Nr.p.k., } \\
\text { dzimums }\end{array}$ & $\begin{array}{c}\text { Pacienta } \\
\text { vecums } \\
\text { saslim- } \\
\text { šanas } \\
\text { sākumā } \\
\text { (SP } \\
\text { sākumā) }\end{array}$ & $\begin{array}{c}\text { Diagnoze } \\
\text { (atradne } \\
\text { muguras } \\
\text { smadzeņu MR } \\
\text { izmeklējumā) }\end{array}$ & $\begin{array}{c}\text { AQP4- } \\
\text { IgG }\end{array}$ & OCB & $\begin{array}{c}\text { Kopējais } \\
\text { slimības } \\
\text { ilgums (laiks } \\
\text { no slimības } \\
\text { sākuma līdz } \\
\text { SP), gados }\end{array}$ & $\begin{array}{c}\text { Progre } \\
\text { sējoša } \\
\text { neiroloǵiskā } \\
\text { deficīta ilgums, } \\
\text { gados }\end{array}$ & $\begin{array}{c}\text { Kopējais } \\
\text { paasinājumu } \\
\text { skaits } \\
\text { (paasinājumu } \\
\text { skaits pirms } \\
\text { SP)* }\end{array}$ & $\begin{array}{c}\text { EDSS } \\
\text { pirms SP }\end{array}$ & $\begin{array}{c}\text { EDSS } \\
\text { pēdējā } \\
\text { novē- } \\
\text { rošanas } \\
\text { vizìtē }\end{array}$ \\
\hline 1. V & $69(71)$ & $\begin{array}{l}\text { NMO (cervikāls } \\
\text { LM) }\end{array}$ & + & - & $6,7(2,7)$ & 4 & $5\left(5^{*}\right)$ & 6,5 & 8,5 \\
\hline $2 . \mathrm{V}$ & $55(58)$ & $\begin{array}{l}\text { NMO (kakla un } \\
\text { krūšu LM) }\end{array}$ & - & - & $9,2(3,9)$ & 5 & $2(2 *)$ & 4,0 & 6 \\
\hline 3. V & $32(52)$ & $\begin{array}{l}\text { NMO (cervikāls } \\
\text { LM) }\end{array}$ & + & + & 30,4 (19) & 3,4 & $2\left(2^{*}\right)$ & 4,0 & 6 \\
\hline 4. $\mathrm{S}$ & $74(76)$ & $\begin{array}{l}\text { NMOS } \\
\text { (torakāls LM) }\end{array}$ & + & $\begin{array}{l}\text { Nav } \\
\text { zināms }\end{array}$ & $8,6(1,5)$ & 7 & $3\left(3^{*}\right)$ & $6,0 / 6,5$ & 8 \\
\hline $5 . \mathrm{S}$ & $32(50)$ & $\begin{array}{l}\text { NMO (cervikāls } \\
\text { LM) }\end{array}$ & + & $\begin{array}{l}\text { Nav } \\
\text { zināms }\end{array}$ & $12(7)$ & 5 & $1(1)$ & 4,0 & 7,5 \\
\hline Vidējais & $\begin{array}{l}52,4 \\
(61,4)\end{array}$ & - & $\begin{array}{l}\text { AQP4- } \\
\text { IgG (+) } \\
80 \%\end{array}$ & - & $13,38(6,82)$ & 4,88 & $2,6\left(2,6^{*}\right)$ & 5 & 7 \\
\hline
\end{tabular}

* pēdējais uzskaitītais paasinājums iespējams vērtējams kā SP norises sākums nevis paasinājums; EDSS - neiroloğiskā stāvokḷa izmeklējuma skala, MRC - medical research council skala muskuḷu spēka noteikšanai,

V - vīrietis, S - sieviete, SP - sekundāri progresīva norise, MR - magnētiskā rezonanse, '+'pozitīvs, '-'negatīvs, LM - longitudināls mielīts, IVIG - imūnglobulīni intravenozi, OCB - oligoklonālās k̦ēdes (oligoclonal bands) 


\subsubsection{Neiropātiska nieze}

Pētījumā tika iekl̦auti 44 slimnieki, kas tika padziḷināti intervēti vidēji 64 (4-444) mēnešus pēc NMO saslimšanas sākuma. Niezi anamnēzē (kopš pirmo NMO simptomu parādī̌sanās) atzīmēja 15/44 slimnieku. Neiropātisku niezi (NN) jeb niezi bez izsitumiem vai citiem pavadošiem sistēmiskiem simptomiem anamnēzē (kopš pirmo NMO simptomu parādīšanās) atzīmēja 27,3\% (12/44: 2 vīrieši un 10 sievietes) no visiem NMO / NMOS pacientiem. Trīs citos gadījumos tā bija saistīta ar sistēmisku reakciju (alergisiska reakcija, hiperbilirubinēmija vai nieze kā izolēts simptoms bez pavadošiem citiem neiroloǵiskiem simptomiem), tādēl turpmākā analīzē netika iekl̦auti. Vidējais NN slimnieku vecums bija 45 (33-77) gadi.

Mielīts vai stumbra bojājums anamnēzē, kas apstiprināts MR, bija konstatêts visiem 12 slimniekiem. 25\% (3/12) gadījumu nieze izpaudās kā pirmais mielīta simptoms, citiem simptomiem (ietverot $\mathrm{NN}$ skartos segmentus) attīstoties mediāni 5 (2-28) dienas vēlāk. Vienā no šiem gadījumiem NN bija pirmās NMO paasinājuma pirmais simptoms. Tomēr vairums slimnieku (9/12) NN atzīmēja mediāni 7 (1-120) dienas pēc mielītam raksturīgo sensori-motoro simptomu parādīšanās. Niezes skartie segmenti atbilda pārējo sensori-motoro simptomu lokalizācijai (skat. 2.4. tabulu).

Visbiežāk NN skartās ķermeņa daļas bija: ekstremitātes (75\%), rumpis (67\%) un pakauša apvidus (25\%). 91,7\% (11/12) pacientu ziņoja par NN pavadošiem citiem jušanas traucējumiem: parestēzijas $(n=2)$, hiperestēzija $(\mathrm{n}=1)$, nejūtīgums $(\mathrm{n}=7)$, sāpes $(\mathrm{n}=7)$, kas attīstījās mediāni 8,5 dienu laikā. $50 \%(6 / 12)$ gadījumu nieze izpaudās paroksizmu veidā, mediāni $1-5$ reizes dienā 240 (10-600) sekundes katrs. Savukārt, 41,67\% (5/12) NN atzīmēja kā pastāvīgu - mediāni 3 (1-104) nedēlu garumā, bet vienā gadījumā tā ilga apmēram 60 minūtes. Mediānā NN izteiktības pakāpe bija 6/10 (2-9), un apmēram pusē gadījumu pieskārieni, karsts ūdens vai sāpes to pastiprināja. Trijos gadījumos skartās vietas kasīšana sniedza īslaicīgu atvieglojuma sajūtu, bet vienā gadījumā tā niezi pastiprināja. Citas fokālas pazīmes tādas kā pastiprinātu ādas svī̌sanu, apsārtumu vai hipertermiju niezes rajonā norādīja 2 slimnieki. 
Neiropātiskas niezes slimnieku vispārējs raksturojums

\begin{tabular}{|c|c|c|c|c|c|c|}
\hline $\begin{array}{l}\text { Nr. p.k., } \\
\text { dzimums, } \\
\text { vecums }\end{array}$ & $\begin{array}{c}\text { TM } \\
\text { epizode } \\
\text { ar NN }\end{array}$ & $\begin{array}{l}\text { Laika intervāls starp NN un } \\
\text { mielīta simptomiem }\end{array}$ & MR atradne & NN lokalizācija & $\begin{array}{c}\mathrm{NN} \\
\text { intensitāte }\end{array}$ & $\begin{array}{c}\text { Vidējais (kopējais) NN } \\
\text { epizodes ilgums un biežums }\end{array}$ \\
\hline 1. S, 77 & $1,4,9$ & $\begin{array}{l}5 \text { dienas pirms nejūtīguma } \\
\text { labajā rokā }\end{array}$ & C1-7 & Labais plecs & 4 & 3 min (dažas dienas) \\
\hline 2. S, 54 & 1 & $\begin{array}{l}4 \text { dienas pēc sāpēm, } \\
\text { hiperestēzijas, parestēzijām } \\
\text { labajā rokāa }\end{array}$ & $\begin{array}{l}\text { C2-4, Th2, } \\
\text { Th8-9 }\end{array}$ & $\begin{array}{l}\text { Labā roka, pakauša } \\
\text { rajons }\end{array}$ & 5 & $\begin{array}{l}3 \text { min katrs, uznākot un } \\
\text { pārejot visas dienas garumā } \\
\text { (10 dienas) }\end{array}$ \\
\hline $3 . \mathrm{V}, 74$ & 1 & $\begin{array}{l}4 \text { mēnešus pēc sāpēm, } \\
\text { nejūtīguma, vājuma labās } \\
\text { puses locekḷ̆os }\end{array}$ & $\mathrm{C} 4, \mathrm{C} 7$ & $\begin{array}{l}\text { Spranda, krūšu dạ̦a, } \\
\text { labais plecs, labais } \\
\text { cirksnis }\end{array}$ & 5 & $\begin{array}{l}10 \text { min, maksimums } 1-2 \\
\text { reizes dienā (nav zināms) }\end{array}$ \\
\hline 4. S, 43 & 2 & $\begin{array}{l}1 \text { nedēlu pēc nejūtīguma } \\
\text { kreisajā rokā un sānā }\end{array}$ & $\mathrm{KCP}-\mathrm{C} 7$ & $\begin{array}{l}\text { Muguras augšpuse, } \\
\text { kreisā auss, kakls, vēdera } \\
\text { rajons, abas rokas }\end{array}$ & 5 & $\begin{array}{l}5 \text { min, } 5 \text { reizes dienā } \\
(1 \text { mēnesi) }\end{array}$ \\
\hline 5. S, 39 & 2 & $\begin{array}{l}10 \text { dienas pēc sāpēm, } \\
\text { parestēzijām krūšu daḷā }\end{array}$ & $\mathrm{KCP}-\mathrm{Th} 7$ & Krūšu augšdaļa & 8 & $\begin{array}{l}4 \text { min katrs, uznākot un } \\
\text { pārejot visas dienas garumā, } \\
\text { ( } 6 \text { mēneši) }\end{array}$ \\
\hline 6. V, 34 & 1 & $\begin{array}{l}5 \text { nedēlas pēc nejūtīguma } \\
\text { (tam sākot izzust) augšstilbos }\end{array}$ & Th1-12 & Abi augšstilbi & 7 & $\begin{array}{l}3 \text { min, } 1-2 \text { reizes dienā } \\
(1 \mathrm{gadu})\end{array}$ \\
\hline 7. S, 33 & 2,4 & $\begin{array}{l}2 \text { epizodes saistītas ar } 2 \\
\text { atsevišķiem paasinājumiem: } \\
\text { 1.) } 2 \text { nedēlas pēc TM; 2.) } 4 \\
\text { nedēḷas pirms TM }\end{array}$ & MO-Th12 & Visi 4 locekḷi un rumpis & 8 & Nepārtraukti (1 mēnesi) \\
\hline
\end{tabular}


2.4. tabulas turpinājums

\begin{tabular}{|c|c|c|c|c|c|c|}
\hline $\begin{array}{l}\text { Nr. p.k., } \\
\text { dzimums, } \\
\text { vecums }\end{array}$ & $\begin{array}{c}\text { TM } \\
\text { epizode } \\
\text { ar NN } \\
\end{array}$ & $\begin{array}{l}\text { Laika intervāls starp NN un } \\
\text { mielìta simptomiem }\end{array}$ & MR atradne & NN lokalizācija & $\begin{array}{c}\mathrm{NN} \\
\text { intensitāte }\end{array}$ & $\begin{array}{c}\text { Vidējais (kopējais) NN } \\
\text { epizodes ilgums un biežums }\end{array}$ \\
\hline 8. S, 50 & 1 & $\begin{array}{l}2 \text { dienas pēc žagošanās, } \\
\text { vemšanas, tetraparēzes }\end{array}$ & $\begin{array}{l}\text { MO-conus } \\
\text { medullaris }\end{array}$ & Abas rokas & 8 & Nepārtraukti (1 mēnesi) \\
\hline 9. S, 54 & 1,3 & $\begin{array}{l}\text { Dažas stundas pēc } \\
\text { dubultošanās, vemšanas, } \\
\text { sāpēm labajā plecā }\end{array}$ & $\mathrm{MO}-\mathrm{C} 1$ & $\begin{array}{l}\text { Labais plecs, roka, } \\
\text { rumpja augšdaḷa }\end{array}$ & 7 & Nepārtraukti (dažas nedēļas) \\
\hline 10. S, 45 & 1 & $\begin{array}{l}2 \text { dienas pirms labās puses } \\
\text { locekḷu vājuma, parestēzijām, } \\
\text { sāpēm, nejūtīguma }\end{array}$ & $\mathrm{C} 3-\mathrm{C} 5$ & Virs labās lāpstiņas & 9 & Nepārtraukti (2 nedēlas) \\
\hline 11. S, 45 & 1 & $\begin{array}{l}2 \text { nedēḷu laikā kopš vājuma, } \\
\text { nejūtīguma locekḷos }\end{array}$ & $\mathrm{C} 2-5$ & $\begin{array}{l}\text { Pakauša rajons, kakls, } \\
\text { labais augšdelms }\end{array}$ & 5 & Nepārtraukti (1 nedēḷ) \\
\hline 12. S, 36 & 1 & $\begin{array}{l}2 \text { dienas pēc sāpēm, vājuma, } \\
\text { spazmām labās puses } \\
\text { locekḷos }\end{array}$ & $\begin{array}{l}\text { Sākot no } \\
\text { iegarenām } \\
\text { smadzenēm } \\
\text { līdz muguras } \\
\text { smadzeṇu } \\
\text { krūšu daḷas } \\
\text { vidum }\end{array}$ & $\begin{array}{l}\text { Labā plauksta, sprandas } \\
\text { kreisā puse }\end{array}$ & 2 & $\begin{array}{l}1 \text { stundu katrs, } 5 \text { reizes dienā } \\
\text { (1 nedēḷu) }\end{array}$ \\
\hline
\end{tabular}

$\mathrm{S}$ - sieviete, V - vīrietis, LM - longitudināls mielīts, TM - transversāls mielīts, NN - neiropātiska nieze, MR - magnētiskā rezonanse, KCP kraniocervikālā pāreja, MO - iegarenās smadzenes, C - muguras smadzeņu kakla daļas segmenti, Th - muguras smadzeṇu krūšu dą̧as segmenti, conus medullaris - muguras smadzen̦u konusa dạ̦a 


\subsubsection{Toniskas spazmas}

No 44 pētījumā iekḷautajiem AQP4-IgG pozitīviem pacientiem par TS anamnēzē ziņoja 55\% (24/44). Divos gadījumos klīniskie dati bija nepilnīgi, tādēl tie padziḷināti netika analizēti.

Padziļināti tika intervēti 22 pacienti: 20 sievietes un 2 vīrieši (vidēji 64 (4-444) mēnešus pēc NMO saslimšanas sākuma). Intervijas laikā slimnieku mediānais vecums bija 50 (14-76), bet saslimšanas sākumā - 43 (7-69) gadi. Mediānais slimības ilgums bija 79 (11-443) mēneši, bet no saslimšanas sākuma līdz TM, pēc kura novēroja TS - 14 (0-300) mēneši. 54,5\% gadījumu TS parādījās PKE laikā vai pēc tās: 40,1\% (n = 9) mēneša laikā, 59,9\% (n=13) mediāni $2(0,5-8)$ mēnešu laikā. Vienam pacientam (4,5\%) TS izpaudās kā NMO paasinājuma pirmais simptoms, citiem sensori-motoriem traucējumiem attīstoties 2 nedēḷas vēlāk.

TS biežums variēja robežās no 1 paroksizma dienā līdz pat spazmu epizodei ik pa 10 minūtēm. Mediānais katras TS epizodes ilgums bija 40 (10-240) sekundes. Pacienti ziņoja par TS attīstību jebkurā diennakts laikā, $54 \%$ - vienīgi rīta vai vakara stundās. Atsevišksos gadījumos pacienti spazmu dēl atzīmēja arī traucētu miegu, bet $63,6 \%$ ziņoja par TS pavadošu izteiktu sāpju sajūtu. 57\% pacientu spazmi bija ierobežoti tikai kājās un 4\% tikai rokās, bet atlikušajiem 39\% spazmas novēroja gan rokās, gan kājās. TS lokalizācija atspoguḷota 2.1. attēlā. Spazmas provocējošus faktorus atzīmēja 63,6\% (n=14) pacientu: mehānisks spiediens jeb pieskāriens $-4,5 \%(\mathrm{n}=1)$, ķermeṇa stāvokḷa maiņa, kustība jeb fiziska aktivitāte $-50 \%(\mathrm{n}=11)$, stress $-4,5 \%(\mathrm{n}=1)$, aukstums $-4,5 \%(\mathrm{n}=1)$.

Saņemtā ārstēšana TS kupēšanai bija zināma 17 pacientiem. 12/17 pacienti san̄ēma karbamazepīnu, un 9 (75\%) no tiem ar mērenu vai labu efektivitāti. Baklofēnu saṇēma 6 pacienti, taču neviens no tiem neuzrādīja nozīmīgu uzlabojumu. Spazmu terapijā ar nelielu simptomu uzlabojumu tika pielietots arī klonazepāms, pregabalīns, gabapentīns, fenitoīns, lamotridžīns. 


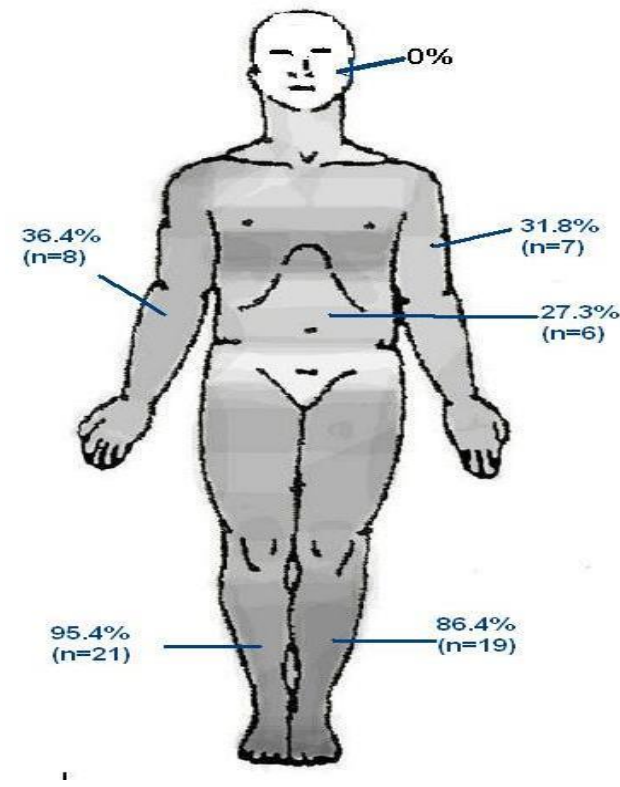

2.1. attēls. Tonisku spazmu lokalizācija

\subsubsection{MOG-IgG pozitīvu pacientu fenotips}

Kārtējo klīnisko vizīšu ietvaros līdz 2014. gada maijam MOG-IgG1 antivielas bija noteiktas 98 pacientiem ar sekojošām diagnozēm: 21 no 24 AQP4-IgG negatīvi NMO, 77 aizdomu NMOS saslimšana (AQP4-IgG negatīvs monofāzisks vai recidivējošs redzes nerva neirīts, mielīts vai stumbra bojājums, kas neatbilst NMO vai MS diagnostiskiem kritērijiem). MOG-IgG1 bija pozitīvas 11 no 98 testētajiem slimniekiem ( 5 sievietes un 6 vīrieši).

Starp MOG-IgG1 pozitīviem pacientiem bija: 8 AQP4-IgG negatīvi NMO (sastāda 38\% jeb 8 no 21 AQP4-IgG negatīviem NMO), 1 monofāziska optikospināla demielinizācija, 1 monofāzisks mielīts, 1 recidivējošs mielīts ar smadzeņu stumbra bojājumu. Recidivējošu slimības norisi novēroja 64\% (7/11), skat. 2.5. tabulu. To vidējais vecums saslimšanas sākumā bija $20 \pm 9$, bet slimības ilgums $-7,9 \pm 5$ gadi, savukārt monofāzisku pacientu $-29,5 \pm 12$ un 1,3 \pm 0,7 gadi. Atradne pirmreizējā galvas smadzeņu MR izmeklējumā: 9 - normāla, 1 - nespecifiskas baltās vielas izmaiņas, 1 - perēkḷi smadzeṇu stumbrā. 


\subsection{Optiskā neiromielīta ārstēšanas raksturojums}

\subsubsection{Recidīvu ārstēšana ar IVIG}

\subsubsection{Pacientu raksturojums un IVIG indikācijas}

Izanalizējot datus par 93 slimniekiem, pētījumā identificēti 15 NMO slimnieki, kas saņēmuši IVIG akūtu paasinājumu ārstēšanā. 5 gadījumos iegūt pilnvērtīgu klīnisko informāciju nebija iespējams, tādēl turpmākajā analīzē iekḷauti dati par 10 pacientiem (8 sievietes un 2 vīrieši, 8 AQP4-IgG pozitīvi), tie apkopoti 2.6. tabulā.

Ārstēšanas brīdī mediānais pacientu vecums bija $41,9(7,4-79,0)$ un slimības ilgums - 3,3 $(0,5-16,6)$ gadi.

IVIG $2 \mathrm{~g}$ uz kg ķermeña svara 5 dienu kursa veidā sañēma $10 \mathrm{NMO} /$ NMOS pacienti 11 recidīvu kupēšanai: 7 - TM un 4 - abpusējs ON. Desmit gadījumos pirms IVIG bija saņemti kortikosterōidi 3-5 dienu intravenoza kursa veidā un 5 gadījumos arī PLEX. Visos gadījumos funkciju atjaunošanās, neskatoties uz saņemto terapiju, bija nepiln̄̄ga un tika uzsākti IVIG. Vienam NMO pacientam IVIG uzsāka kā pirmās līnijas terapiju, jo sākotnēji bija kḷūdaini noteikta GBS diagnoze (GBS ārstēšanu nereti uzsāk ar IVIG). Citā gadījumā PLEX netika uzsākta iespējamu blakusefektu dẹ̄̂; pārējos gadījumos iemesli, kādēḷ priekšroka dota IVIG, nevis PLEX, nav zināmi. Pēc akūtā terapijas kursa pabeigšanas visi pacienti sañēma turpmāku ārstēšanu: 1 - IVIG atkārtotu kursu veidā ik pa 6-8 nedēlāam, 9 - kortikosteroīdus perorāli.

\subsubsection{Terapijas efektivitāte un blaknes}

IVIG ārstēšanu uzsāka mediāni $0,5(0-6)$ mēnešus pēc paasinājuma sākuma. Izteikts funkciju zudums pirms ārstēšanas bija vērojams visos gadījumos.

Savukārt mediāni 2 (0-12) mēnešus pēc ārstēšanas kursa beigām, bija vērojams EDSS skalas uzlabojums par 0,5 punktiem, respektīvi, no EDSS 7,0 (4-7,5) uz EDSS 6,5 (3-9). Kopumā funkciju uzlabošanās bija reǵistrēta 45,5\% (5/11). Vienā no šiem 5 gadījumiem - slimniecei (2.6. tabula, gadījums Nr. 1) ar sākotnēju, kḷūdaini noteiktu, GBS diagnozi un izteiktu neirologiisko funkciju zudumu (guloša, sekundāra elpošanas mazspēja, EDSS 9) IVIG uzsāka agrīni. Pēc pozitīvu AQP4-IgG rezultātu saņemšanas viṇa uzsāka arī kortikosteroīdus 
perorāli; 2 mēnešus pēc IVIG terapijas kursa bija vērojams izteikts stāvokḷa uzlabojums (EDSS 6,5). Arī kādai citai guḷošai (EDSS 8,5) slimniecei ar sekundāru elpošanas mazspēju (2.6. tabula, gadījums Nr. 4), kam IVIG uzsāka 14 dienas pēc recidīva sākuma ( 4 mēnešus pēc iepriekšèjā mielīta un izteiktiem reziduāliem kustību traucējumiem, EDSS 6,5) fiksēts nozīmīgs neirologisko funkciju uzlabojums. 
MOG-IgG pozitīvu gadījumu raksturojums

\begin{tabular}{|c|c|c|c|c|c|c|c|c|}
\hline $\begin{array}{l}\text { Nr., } \\
\text { Dz./ } \\
\text { vecums } \\
\text { PA }\end{array}$ & $\begin{array}{c}\text { Slimības } \\
\text { ilgums, } \\
\text { (KRS) }\end{array}$ & $\begin{array}{l}\text { Klīniskais } \\
\text { fenotips } \\
\text { (notikumu } \\
\text { skaits) }\end{array}$ & $\begin{array}{c}\text { Periods starp } \\
\text { pirmo un otro } \\
\text { paasinājumu } \\
\text { (intervāls } \\
\text { starp pirmo } \\
\text { ON un TM) }\end{array}$ & $\begin{array}{c}\text { Atradne muguras } \\
\text { smadzen̦u MR: } \\
\text { longitudināls } \\
\text { perēklis (perēkḷa } \\
\text { lokalizācija) }\end{array}$ & $\begin{array}{c}\text { Likvors: OCB } \\
\text { (citoze) }\end{array}$ & $\begin{array}{c}\text { Funkciju } \\
\text { atjaunošanās } \\
\text { pēc pirmā } \\
\text { paasinājuma }\end{array}$ & $\begin{array}{c}\text { EDSS } \\
\text { (redzes } \\
\text { traucējumi) } \\
\text { PA }\end{array}$ & $\begin{array}{c}\text { Pašreizējā } \\
\text { ārstēšana }\end{array}$ \\
\hline $\begin{array}{l}1 . S, \\
26\end{array}$ & $\begin{array}{l}12,6 \text { gadi } \\
(13)\end{array}$ & $\begin{array}{l}\text { ON (13) un } \\
\text { TM (1) }\end{array}$ & $\begin{array}{l}4 \text { gadi } \\
(7 \text { gadi })\end{array}$ & $\begin{array}{l}\text { Longitudināls } \\
(\mathrm{KCP}-\mathrm{C} 7, \mathrm{Th} 2-8)\end{array}$ & $\begin{array}{l}\text { Neg, (nav } \\
\text { zināms) }\end{array}$ & Pilnīga & $4(6)$ & $\begin{array}{l}\text { IVIG pulsa } \\
\text { veidā ik pa } 6 \\
\text { nedēlām un p/o } \\
\text { prednizolons }\end{array}$ \\
\hline $\begin{array}{l}2 . \mathrm{V}, \\
19\end{array}$ & $\begin{array}{l}3,9 \\
\operatorname{gadi}(7)\end{array}$ & $\begin{array}{l}\mathrm{ON}(>7) \text { un } \\
\mathrm{TM}(2)\end{array}$ & $\begin{array}{l}2 \text { mēneši } \\
\text { (vienlaic̄igi) }\end{array}$ & $\begin{array}{l}\text { Longitudināls } \\
\text { (Th4-11) }\end{array}$ & $\begin{array}{l}\text { Nav zināms } \\
\text { (14) }\end{array}$ & $\begin{array}{l}\text { Gandrīz } \\
\text { pilnīga }\end{array}$ & $3(5)$ & $\begin{array}{l}\text { Rituksimabs, } \\
\text { IVIG pulsa } \\
\text { veidā ik pa } 6 \\
\text { nedēlām un p/o } \\
\text { prednizolons }\end{array}$ \\
\hline $\begin{array}{l}3 . \mathrm{V}, \\
26\end{array}$ & $\begin{array}{l}7,4 \text { gadi } \\
(3)\end{array}$ & $\begin{array}{l}\text { ON (2) un } \\
\text { TM (1) }\end{array}$ & $\begin{array}{l}6 \text { gadi } \\
(6 \text { gadi })\end{array}$ & $\begin{array}{l}\text { Longitudināls } \\
\text { (C6-conus } \\
\text { medullaris) }\end{array}$ & $\begin{array}{l}\text { Nav zināms } \\
(272)\end{array}$ & Dal̦ēja & $4(1)$ & $\begin{array}{l}\text { Mikofenolāta } \\
\text { mofetils }\end{array}$ \\
\hline 4. S, 20 & $\begin{array}{l}15,6 \\
\operatorname{gadi}(2)\end{array}$ & $\begin{array}{l}\text { ON (1) un } \\
\text { TM (1) }\end{array}$ & $\begin{array}{l}4 \text { gadi (4 } \\
\text { gadi) }\end{array}$ & $\begin{array}{l}\text { Longitudināls } \\
\text { (MO-C7) }\end{array}$ & Neg. (13) & $\mathrm{Nav}$ & $9(1)$ & $\begin{array}{l}\text { Azatioprīns un } \\
\text { p/o } \\
\text { prednizolons }\end{array}$ \\
\hline
\end{tabular}


2.5. tabulas turpinājums

\begin{tabular}{|c|c|c|c|c|c|c|c|c|}
\hline $\begin{array}{l}\text { Nr., } \\
\text { Dz./ } \\
\text { vecums } \\
\text { PA }\end{array}$ & $\begin{array}{l}\text { Slimības } \\
\text { ilgums, } \\
\text { (KRS) }\end{array}$ & $\begin{array}{l}\text { Klīniskais } \\
\text { fenotips } \\
\text { (notikumu } \\
\text { skaits) }\end{array}$ & $\begin{array}{l}\text { Periods starp } \\
\text { pirmo un otro } \\
\text { paasinājumu } \\
\text { (intervāls } \\
\text { starp pirmo } \\
\text { ON un TM) }\end{array}$ & $\begin{array}{l}\text { Atradne muguras } \\
\text { smadzenuu MR: } \\
\text { longitudināls } \\
\text { perēklis (perēkḷa } \\
\text { lokalizācija) }\end{array}$ & $\begin{array}{l}\text { Likvors: OCB } \\
\text { (citoze) }\end{array}$ & $\begin{array}{c}\text { Funkciju } \\
\text { atjaunošanās } \\
\text { pēc pirmā } \\
\text { paasinājuma }\end{array}$ & $\begin{array}{c}\text { EDSS } \\
\text { (redzes } \\
\text { traucējumi) } \\
\text { PA }\end{array}$ & $\begin{array}{c}\text { Pašreizējā } \\
\text { ārstěšana }\end{array}$ \\
\hline 5. S, 21 & $\begin{array}{l}13,6 \text { gadi } \\
\text { (3) }\end{array}$ & $\begin{array}{l}\text { ON (2), TM } \\
\text { (2), cerebrāls } \\
\text { (1) }\end{array}$ & $\begin{array}{l}1 \text { gads (1 } \\
\text { gads) }\end{array}$ & $\begin{array}{l}\text { Longitudināls } \\
\text { (visā muguras } \\
\text { smadzeņu } \\
\text { garumā) }\end{array}$ & Neg. (264) & $\begin{array}{l}\text { Gandrīz } \\
\text { pilnīga }\end{array}$ & $6(0)$ & $\begin{array}{l}\text { Azatioprīns un } \\
\text { p/o } \\
\text { prednizolons }\end{array}$ \\
\hline $\begin{array}{l}\text { 6. V, } \\
22\end{array}$ & $\begin{array}{l}6,1 \text { gadi } \\
\text { (2) }\end{array}$ & $\begin{array}{l}\text { ON (1), TM } \\
(1), \text { cerebrāls } \\
\text { (1) }\end{array}$ & $\begin{array}{l}3 \text { mēneši (3 } \\
\text { mēneši) }\end{array}$ & $\begin{array}{l}\text { Longitudināls } \\
\text { (Th3-7, } \\
\text { Th9-11) }\end{array}$ & $\begin{array}{l}\text { Neg. (nav } \\
\text { zināms) }\end{array}$ & $\begin{array}{l}\text { Gandrīz } \\
\text { pilnīga }\end{array}$ & $1(1)$ & $\begin{array}{l}\text { Azatioprīns un } \\
\text { p/o } \\
\text { prednizolons }\end{array}$ \\
\hline 7.V, 42 & $\begin{array}{l}2,3 \text { gadi } \\
\text { (1) }\end{array}$ & $\begin{array}{l}\text { ON (1) un } \\
\text { TM (1) }\end{array}$ & $\begin{array}{l}\text { Tikai 1 P } \\
\text { (vienlaicīgi) }\end{array}$ & $\begin{array}{l}\text { Longitudināls } \\
\text { (C2-7, Th6, Th9- } \\
\text { conus medullaris) }\end{array}$ & Neg. (161) & $\begin{array}{l}\text { Gandrīz } \\
\text { pilnīga }\end{array}$ & $2(1)$ & $\mathrm{Nav}$ \\
\hline $8 . S, 41$ & $1(1)$ & $\begin{array}{l}\text { ON (1) un } \\
\text { TM (1) }\end{array}$ & $\begin{array}{l}\text { Tikai } 1 \mathrm{P} \\
\text { (vienlaicīgi) }\end{array}$ & $\begin{array}{l}\text { Longitudināls } \\
\text { (Th8-12) }\end{array}$ & Neg. (189) & Dal̦ēja & $5,5(2)$ & $\mathrm{Nav}$ \\
\hline $9 . \mathrm{V}, 20$ & $1(1)$ & $\begin{array}{l}\text { ON (1) un } \\
\text { TM (1) }\end{array}$ & $\begin{array}{l}\text { Tikai 1 P } \\
\text { (vienlaicīgi) }\end{array}$ & $\begin{array}{l}\text { İsi, nesaplūstoši } \\
\text { plankumveida } \\
\text { (visā m.sm. } \\
\text { garumā) }\end{array}$ & Neg. (140) & $\begin{array}{l}\text { Gandrīz } \\
\text { pilnīga }\end{array}$ & $1,5(1)$ & $\mathrm{Nav}$ \\
\hline
\end{tabular}


2.5. tabulas turpinājums

\begin{tabular}{|c|c|c|c|c|c|c|c|c|}
\hline $\begin{array}{c}\text { Nr., } \\
\text { Dz./ } \\
\text { vecums } \\
\text { PA }\end{array}$ & $\begin{array}{l}\text { Slimības } \\
\text { ilgums, } \\
\text { (KRS) }\end{array}$ & $\begin{array}{l}\text { Klīniskais } \\
\text { fenotips } \\
\text { (notikumu } \\
\text { skaits) }\end{array}$ & $\begin{array}{l}\text { Periods starp } \\
\text { pirmo un otro } \\
\text { paasinājumu } \\
\text { (intervāls } \\
\text { starp pirmo } \\
\text { ON un TM) }\end{array}$ & $\begin{array}{l}\text { Atradne muguras } \\
\text { smadzennu MR: } \\
\text { longitudināls } \\
\text { perēklis (perēkḷa } \\
\text { lokalizācija) }\end{array}$ & $\begin{array}{l}\text { Likvors: OCB } \\
\text { (citoze) }\end{array}$ & $\begin{array}{c}\text { Funkciju } \\
\text { atjaunošanās } \\
\text { pēc pirmā } \\
\text { paasinājuma }\end{array}$ & $\begin{array}{c}\text { EDSS (redzes } \\
\text { traucējumi) } \\
\text { PA }\end{array}$ & $\begin{array}{c}\text { Pašreizējā } \\
\text { ārstēšana }\end{array}$ \\
\hline $\begin{array}{l}10 . \mathrm{V}, \\
40\end{array}$ & $1,8(2)$ & $\begin{array}{l}\text { TM (1) un } \\
\text { smadzeņu } \\
\text { stumbra } \\
\text { bojājums (1) }\end{array}$ & $\begin{array}{l}2 \text { mēneši } \\
\text { (optisks } \\
\text { neirīts nav } \\
\text { bijis) }\end{array}$ & $\begin{array}{l}\text { Longitudināls } \\
\text { (precīza } \\
\text { lokalizācija nav } \\
\text { zināma) }\end{array}$ & Neg. (35) & Pilnīga & $6(0)$ & $\begin{array}{l}\text { Azatioprīns un } \\
\text { p/o } \\
\text { prednizolons }\end{array}$ \\
\hline $\begin{array}{l}11 . \\
S, 19\end{array}$ & $0,8(1)$ & TM (1) & $\begin{array}{l}\text { Tikai } 1 \mathrm{P} \\
\text { (tikai mielīts) }\end{array}$ & $\begin{array}{l}\text { Longitudināls } \\
\text { (C2-Th12) }\end{array}$ & Nav zināms & Dal̦ēja & $6,5(0)$ & $\begin{array}{l}\text { Mikofenolāta } \\
\text { mofetils un p/o } \\
\text { prednizolons }\end{array}$ \\
\hline
\end{tabular}

Dz. - dzimums, S - sieviete, V - vīrietis, MR - magnētiskā rezonanse, C - cervikāls, Th - torakāls, MO - iegarenās smadzenes,

KCP - kraniocervikālā pāreja, EDSS - izvērstā invaliditātes (neiroloǵisko funkciju traucējumu) skala, IVIG - imūnglobulīni intravenozi, p/o -perorāli, ON - redzes nerva neirīts, TM - transversāls mielīts, Neg. - negatīvs, PA - pēdējā apmeklējumā, KRS - kopējais recidīvu skaits, P - paasinājums, m. sm. - muguras smadzenes, OCB - oligoklonālās k̦ēdes (oligoclonal bands) 
Iepriekšējai ārstěšanai ar kortikosteroīdiem nebija klīniski nozīmīga efekta, taču 3 mēnešus pēc IVIG terapijas kursa viņa jau spēja pārvietoties bez atbalsta (EDSS 4,5). Līdzīgi bija arī 3 citos gadījumos (2.6. tabula, gadījumi Nr. 6, 7, 9), kad pēc ārstēšanas ar IVIG (7-9 dienu laikā kopš recidīva sākuma; pēc kortikosteroīdu neefektivitātes), novēroja ievērojamu uzlabojumu. Nozīmīga redzes atjaunošanās (no EDSS 4 uz EDSS 3) fiksēta arī AQP4-IgG negatīvai slimniecei (2.6. tabula, gadījums Nr. 9) ar izteiktu abpusēju redzes zudumu. Interesants ir fakts, ka, ārstējot iepriekšējos paasinājumus, viņa vairākkārt bija saṇēmusi plazmaferēzi, taču bez klīniski nozīmīga efekta.

Blakusefekti, kas varētu būt saistîti ar IVIG, reǵistrēti 2 gadījumos. Pacientei, kam 7 dienas pēc pēdējā IVIG infūza attīstîjās pneimonija un miokarda infarkts ( $\uparrow \mathrm{T}$ troponīns), sākotnēji tika novērota stāvokḷa uzlabošanās un viņa tika izrakstīta no stacionāra turpmākai sociālai aprūpei, taču 3 nedēḷas vēlāk iestājās exitus letalis (nāves cēlonis - pneimonija). Jāuzsver, ka pirms IVIG uzsākšanas š̄̄ slimniece bija ar izteiktu invaliditāti (tetrapleǵija), kam ārstēšana ar steroīdiem izrādījās neefektīva, savukārt PLEX sakarā ar lielo vecumu un paaugstinātu trombotisku komplikāciju risku šķita kontrindicēta.

\subsection{2. Ārstēšana ar azatioprīnu}

\subsubsection{Pacientu un terapijas vispārējs raksturojums}

AZA saņēma 103 slimnieki: 91 (88\%) sieviete un 12 (12\%) vīrieši. 60 no tiem ar apstiprinātu NMO diagnozi, bet 43 - NMOS. AZA uzsāka mediāni 2 (0-31) gadus pēc saslimšanas sākuma un pēc 3 (0-22) paasinājumiem. Divos gadījumos AZA uzsāka vēl pirms NMO/NMOS simptomu sākuma: pacientam ar sistēmisko vilkēdi (1 mēnesi pirms) un pacientam ar miastēniju (2,5 gadus agrāk). Uzsākot AZA, pacientu mediānais vecums bija 45,8 $(3,7-79,0)$ un pēdējā novērošanas vizìtē - 50 (5-80) gadi; 8 pacienti bija jaunāki par 16 gadiem un 11 - vecāki par 65 gadiem.

Mediānais ārstēšanas ilgums ar AZA bija 18 (0,01-256) mēneši. 91/103 (88\%) slimnieku AZA uzsāka kā pirmās līnijas medikamentu (ar vai bez prednizolona), 9 - citu imūnsupresantu neefektivitātes dēl pēc mediāni 5 (3-10) paasinājumiem, 3 - bija sākotnēji kḷūdaini noteikta MS diagnoze un sañēma beta interferonu, glatiramera acetātu vai natalizumabu. Visi šie medikamenti, izṇemot prednizolonu, pirms AZA uzsākšanas tika piln̄īā pārtraukti. Trijos gadījumos AZA terapija bija iniciēta ar vienu ciklofosfamīda intravenozu 
injekciju. Pēdējā novērošanas vizītē mediānā AZA deva bija 125 (25-275) mg; $63 \%(65 / 103)$ pacientu papildus saņēma prednizolonu perorāli mediāni 4,5 (1,25-45) mg dienā.

\subsubsection{Efektivitātes raksturojums: paasinājumu skaits}

Pacientu sadalījumam par pamatu ņemti atlases kritēriji, kas izmantoti ekulizumaba (medikaments ar līdz šim augstāko uzrādīto efektivitāti NMO/NMOS ārstēšanā) pētījumā (Pittock, Lennon et al. 2013).

Visi pacienti $(n=103)$.

89\% (92/103) novēroja RSG samazinājumu - no mediāni 1,5 (IQR, $0,6-4,0)$ pirms uz 0 (IQR, $0-0,27, \mathrm{p}<0,00005)$ pēc ārstēšanas, pilnīgu remisiju - 61\% (63/103). Atlikušie 39\% (40/103) turpināja recidivēt, trešdaļai $(n=12)$ jaunu paasinājumu novērojot jau pirmo 3 mēnešu laikā, pārējiem - mediāni pēc 21 (4-83) mēnešu ārstēšanas perioda. Tomēr, neskatoties uz turpmākiem recidīviem, fiksēts nozīmīgs RSG samazinājums (no 1,65 uz 0,27). Papildu prednizolonu saņēma divas trešdaļas pacientu (gan recidivējušie, gan klīniski stabilie); mediānā deva bija 4 (1,5-30) mg pirmajā un 5 (1,25-45) mg otrajā gadījumā. Slimniekiem ar neefektīvu iepriekšēju imūnsupresiju pēc AZA terapijas fiksēts RSG samazinājums mediāni no $1,7(0,9-3,6)$ uz $0,27(0-1,14)$. 24 pacienti AZA pārtrauca pirmo 6 mēnešu laikā, bet 7 - saṇēma $<6$ mēnešiem, pārējiem (72 gadījumos jeb 70\%) ārstēšanas kurss ar AZA bija $\geq 6$ mēneši ar mediāno RSG (n= 72) samazinājumu no 1,6 (IQR 0,6-4) uz 0,1 (IQR 0-0,5), $\mathrm{p}<0,00005$, pilnīgu remisiju sasniedzot $49 \%(\mathrm{n}=35)$. 
Pacientu, kas saṇēmuši IVIG terapiju, raksturojums

\begin{tabular}{|c|c|c|c|c|c|c|c|c|c|c|c|}
\hline $\begin{array}{l}\text { Nr. } \\
\text { p.k., } \\
\text { vec./ } \\
\text { Dz. }\end{array}$ & $\begin{array}{l}\text { Ar IVIG } \\
\text { ārstētā P } \\
\text { fenotips) }\end{array}$ & AQP4-IgG & $\begin{array}{c}\text { EDSS } \\
\text { (f-ju } \\
\text { deficīts } \\
\text { pirms esošā } \\
\text { paasin.) }\end{array}$ & $\begin{array}{l}\text { IST } \\
\text { pirms } \\
\text { IVIG }\end{array}$ & $\begin{array}{c}\text { Akūtā } \\
\text { perioda } \\
\text { ārstēšana } \\
\text { pirms } \\
\text { IVIG }\end{array}$ & $\begin{array}{l}\text { Indikācija } \\
\text { IVIG }\end{array}$ & $\begin{array}{c}\text { Saņemtā } \\
\text { Tx pēc } \\
\text { IVIG }\end{array}$ & $\begin{array}{l}\text { EDSS } \\
\text { pirms } \\
\text { IVIG }\end{array}$ & $\begin{array}{c}\text { EDSS } \\
\text { pēc IVIG } \\
\text { (laiks } \\
\text { starp Tx } \\
\text { un } \\
\text { nākamo } \\
\text { paasin.) }\end{array}$ & $\begin{array}{c}\text { Obj. } \\
\text { f-ju } \\
\text { uzlaboš } \\
\text { anās }\end{array}$ & $\begin{array}{c}\text { Blak- } \\
\text { nes }\end{array}$ \\
\hline $\begin{array}{l}1 . \\
43, S\end{array}$ & $\begin{array}{l}\text { NMO } \\
\text { (cervikāls } \\
\text { mielīts, } \\
\text { arefleksija, } \\
\text { elpošanas } \\
\text { mazspēja) }\end{array}$ & + & $\begin{array}{l}3 \text { (kreisajā } \\
\text { acī pilnīgs } \\
\text { redzes } \\
\text { zudums) }\end{array}$ & $\mathrm{Nav}$ & $\mathrm{Nav}$ & $\begin{array}{l}\text { Kḷūdaini } \\
\text { diagnosticēt } \\
\text { s kā Gijēna- } \\
\text { Barrē } \\
\text { sindroms }\end{array}$ & Pred. & 9 & $\begin{array}{l}6,5 \\
(2 \\
\text { mēneši) }\end{array}$ & $\overline{\mathrm{Ja}}$ & $\mathrm{Nav}$ \\
\hline $\begin{array}{l}2 . \\
38, \mathrm{~S}\end{array}$ & $\begin{array}{l}\text { NMO } \\
\text { (abpusējs } \\
\text { ON (GU)) }\end{array}$ & + & $\begin{array}{l}3 \text { (NZ, spēj } \\
\text { lasīt lielu } \\
\text { druku) }\end{array}$ & $\begin{array}{l}\text { Metotr } \\
\text { eksāts } \\
\text { kopā ar } \\
\text { KS p/o }\end{array}$ & $\begin{array}{l}\text { PLEX, } \\
\text { pred. }\end{array}$ & $\begin{array}{l}\text { Nav } \\
\text { uzlabo- } \\
\text { šanās no } \\
\text { PLEX un } \\
\text { pred. }\end{array}$ & Pred. & 4 & $\begin{array}{l}4(0,5 \\
\text { mēneši) }\end{array}$ & $\mathrm{Ne}$ & Nav \\
\hline $\begin{array}{l}3 . \\
49, \mathrm{~S}\end{array}$ & $\begin{array}{l}\text { NMO } \\
\text { (torakāls } \\
\text { LM, } \\
\text { muskuļu } \\
\text { spēks kājās } \\
\text { MRC 2- } \\
\text { 3/5) }\end{array}$ & + & $\begin{array}{l}\text { NZ } \\
\text { (spēj } \\
\text { staigāt) }\end{array}$ & $\begin{array}{l}\text { Rituksi } \\
\text { mabs, } \\
\text { ciklofo } \\
\text { sfamīd } \\
\text { s }\end{array}$ & IVMP & $\begin{array}{l}\text { Nav uzlabo- } \\
\text { šanās no } \\
\text { IVMP, } \\
\text { kḷūdaini } \\
\text { diagnosticēts } \\
\text { kā sistēmas } \\
\text { sarkanā } \\
\text { vilkēde }\end{array}$ & $\mathrm{NZ}$ & 7 & $\begin{array}{l}7 \\
(5 \\
\text { mēneši) }\end{array}$ & $\mathrm{Ne}$ & $\mathrm{Nav}$ \\
\hline
\end{tabular}


2.6. tabulas turpinājums

\begin{tabular}{|c|c|c|c|c|c|c|c|c|c|c|c|}
\hline $\begin{array}{l}\text { Nr. } \\
\text { p.k., } \\
\text { vec./ } \\
\text { Dz. }\end{array}$ & $\begin{array}{l}\text { Ar IVIG } \\
\text { ārstētā P } \\
\text { fenotips) }\end{array}$ & AQP4-IgG & $\begin{array}{c}\text { EDSS } \\
\text { (f-ju } \\
\text { deficīts } \\
\text { pirms esošā } \\
\text { paasin.) }\end{array}$ & $\begin{array}{l}\text { IST } \\
\text { pirms } \\
\text { IVIG }\end{array}$ & $\begin{array}{c}\text { Akūtā } \\
\text { perioda } \\
\text { àrstēšana } \\
\text { pirms } \\
\text { IVIG }\end{array}$ & $\begin{array}{l}\text { Indikācija } \\
\text { IVIG }\end{array}$ & $\begin{array}{c}\text { Saņemtā } \\
\text { Tx pēec } \\
\text { IVIG }\end{array}$ & $\begin{array}{l}\text { EDSS } \\
\text { pirms } \\
\text { IVIG }\end{array}$ & $\begin{array}{c}\text { EDSS } \\
\text { pēc IVIG } \\
\text { (laiks } \\
\text { starp Tx } \\
\text { un } \\
\text { nākamo } \\
\text { paasin.) }\end{array}$ & $\begin{array}{c}\text { Obj. } \\
\text { f-ju } \\
\text { uzlaboš } \\
\text { anās }\end{array}$ & $\begin{array}{c}\text { Blak- } \\
\text { nes }\end{array}$ \\
\hline $\begin{array}{l}4 . \\
40, S\end{array}$ & $\begin{array}{l}\text { NMO } \\
\text { (cervikāls } \\
\text { LM, } \\
\text { elpošanas } \\
\text { mazspēja, } \\
\text { muskululu } \\
\text { spēks rokās } \\
\text { un kājās } \\
\text { MRC 2- } \\
\text { 4/5) }\end{array}$ & + & $\begin{array}{l}6,5 \\
\text { (pārvietojas } \\
\text { ar } 2 \text { kruķu } \\
\text { atbalstu; } \\
\text { atjaunoša- } \\
\text { nās fāzē } \\
\text { pēc nesena } \\
\text { paasinā- } \\
\text { juma) }\end{array}$ & Nav & $\begin{array}{l}\text { IVMP } \\
\text { turpinot } \\
\text { ar pred. }\end{array}$ & $\begin{array}{l}\text { Nav } \\
\text { uzlabošanās } \\
\text { no IVMP } \\
\text { un pred. }\end{array}$ & Pred. & 8,5 & $\begin{array}{l}4,5(3 \\
\text { mēneši) }\end{array}$ & Jā & $\mathrm{Nav}$ \\
\hline $\begin{array}{l}5 . \\
79, \mathrm{~S}\end{array}$ & $\begin{array}{l}\text { NMO } \\
\text { (cervikāls } \\
\text { LM, } \\
\text { tetrapa- } \\
\text { rēze, } \\
\text { muskuḷu } \\
\text { spēks rokās } \\
\text { un kājās } \\
\text { MRC-3/5) }\end{array}$ & + & $\begin{array}{l}7 \text { (paraplē- } \\
\text { gija, } \\
\text { pārvietojas } \\
\text { sēdus } \\
\text { krēslā) }\end{array}$ & $\begin{array}{l}\text { Pred. } \\
\text { kopā ar } \\
\text { azatio- } \\
\text { prīnu }\end{array}$ & $\begin{array}{l}\text { IVMP } \\
\text { turpinot } \\
\text { ar pred. }\end{array}$ & $\begin{array}{l}\text { Nav } \\
\text { uzlaboša- } \\
\text { nās no } \\
\text { IVMP un } \\
\text { pred.; } \\
\text { PLEX nav } \\
\text { ieteicama }\end{array}$ & Pred. & 8 & $\begin{array}{l}8 \text { (1 } \\
\text { mēnesis) }\end{array}$ & $\mathrm{Ne \overline { \textrm {e } }}$ & $\begin{array}{l}\text { Mio- } \\
\text { karda } \\
\text { infarkts } \\
\text { (paaugsti- } \\
\text { nāts T } \\
\text { troponīns), } \\
\text { pnei- } \\
\text { monija }\end{array}$ \\
\hline
\end{tabular}


2.6. tabulas turpinājums

\begin{tabular}{|c|c|c|c|c|c|c|c|c|c|c|c|}
\hline $\begin{array}{l}\text { Nr. } \\
\text { p.k., } \\
\text { vec./ } \\
\text { Dz. }\end{array}$ & $\begin{array}{l}\text { Ar IVIG } \\
\text { ārstētā P } \\
\text { fenotips) }\end{array}$ & $\begin{array}{c}\text { AQP4- } \\
\text { IgG }\end{array}$ & $\begin{array}{c}\text { EDSS } \\
\text { (f-ju } \\
\text { deficīts } \\
\text { pirms esošā } \\
\text { paasin.) }\end{array}$ & $\begin{array}{l}\text { IST } \\
\text { pirms } \\
\text { IVIG }\end{array}$ & $\begin{array}{c}\text { Akūtā } \\
\text { perioda } \\
\text { ārstēšana } \\
\text { pirms } \\
\text { IVIG }\end{array}$ & $\begin{array}{l}\text { Indikācija } \\
\text { IVIG }\end{array}$ & $\begin{array}{c}\text { Saņemtā } \\
\text { Tx pēc } \\
\text { IVIG }\end{array}$ & $\begin{array}{c}\text { EDSS } \\
\text { pirms } \\
\text { IVIG }\end{array}$ & $\begin{array}{c}\text { EDSS pēc } \\
\text { IVIG (laiks } \\
\text { starp Tx un } \\
\text { nākamo } \\
\text { paasin.) }\end{array}$ & $\begin{array}{c}\text { Obj. } \\
\text { f-ju } \\
\text { uzlaboš } \\
\text { anās }\end{array}$ & $\begin{array}{c}\text { Blak- } \\
\text { nes }\end{array}$ \\
\hline $\begin{array}{l}6 . \\
57, \mathrm{M}\end{array}$ & $\begin{array}{l}\text { NMO } \\
\text { (cervikāls } \\
\text { un torakāls } \\
\text { LM, } \\
\text { muskulu } \\
\text { spēks rokās } \\
\text { un kājās } \\
\text { MRC } \\
0-3 / 5 \text { ) }\end{array}$ & + & $\begin{array}{l}6,5 \\
\text { (pārvietojas } \\
\text { ar } 2 \text { kruķu } \\
\text { atbalstu) }\end{array}$ & $\begin{array}{l}\text { Azatio } \\
\text { prīns }\end{array}$ & IVMP & $\begin{array}{l}\text { Nav } \\
\text { uzlabošanās } \\
\text { no IVMP }\end{array}$ & NZ & 7 & $\begin{array}{l}6,5 \\
\text { (12 mēn.) }\end{array}$ & Jā & $\mathrm{Nav}$ \\
\hline $\begin{array}{l}7 . \\
38, \mathrm{~S}\end{array}$ & $\begin{array}{l}\text { NMOS } \\
\text { (cervikāls } \\
\text { LM, } \\
\text { muskululu } \\
\text { spēks rokās } \\
\text { un kājās } \\
\text { MRC } \\
1-2 / 5 \text { ) }\end{array}$ & + & $\begin{array}{l}7,5 \\
\text { (tetraparēze, } \\
\text { atjaunošanās } \\
\text { fāzē pēc } \\
\text { nesena } \\
\text { recidīva) }\end{array}$ & Nav & $\begin{array}{l}\text { IVMP, } \\
\text { PLEX } \\
\text { turpinot } \\
\text { ar pred. }\end{array}$ & $\begin{array}{l}\text { Nav } \\
\text { uzlabošanās } \\
\text { no IVMP, } \\
\text { PLEX un } \\
\text { pred. }\end{array}$ & Pred. & 8,5 & $\begin{array}{l}7,5 \\
\text { (3 mēn.) }\end{array}$ & Jā & $\mathrm{Nav}$ \\
\hline $\begin{array}{l}8 . \\
55, \mathrm{~V}\end{array}$ & $\begin{array}{l}\text { NMO } \\
\text { (abpusējs } \\
\text { ON, 1/60) }\end{array}$ & + & $\begin{array}{l}7 \text { (pār- } \\
\text { vietojas } \\
\text { sēdus } \\
\text { krēslā) } \\
\end{array}$ & $\begin{array}{l}\text { Pred., } \\
\text { metotre } \\
\text { ksāts }\end{array}$ & Pred. & $\begin{array}{l}\text { Nav } \\
\text { uzlabošanās } \\
\text { no pred. }\end{array}$ & Pred. & 7 & $\begin{array}{l}7 \\
(0,5 \\
\text { mēn. })\end{array}$ & $\mathrm{Ne \overline { \textrm {e } }}$ & Nav \\
\hline
\end{tabular}


2.6. tabulas turpinājums

\begin{tabular}{|c|c|c|c|c|c|c|c|c|c|c|c|}
\hline $\begin{array}{l}\text { Nr. } \\
\text { p.k., } \\
\text { vec./ } \\
\text { Dz. }\end{array}$ & $\begin{array}{l}\text { Ar IVIG } \\
\text { ārstêtā P } \\
\text { fenotips) }\end{array}$ & $\begin{array}{c}\text { AQP4- } \\
\text { IgG }\end{array}$ & $\begin{array}{c}\text { EDSS } \\
\text { (f-ju } \\
\text { deficīts } \\
\text { pirms esošā } \\
\text { paasin.) }\end{array}$ & $\begin{array}{l}\text { IST pirms } \\
\text { IVIG }\end{array}$ & $\begin{array}{c}\text { Akūtā } \\
\text { perioda } \\
\text { ārstēša } \\
\text { na } \\
\text { pirms } \\
\text { IVIG }\end{array}$ & $\begin{array}{l}\text { Indikācija } \\
\text { IVIG }\end{array}$ & $\begin{array}{c}\text { Saņemtā } \\
\text { Tx pēc } \\
\text { IVIG }\end{array}$ & $\begin{array}{l}\text { EDSS } \\
\text { pirms } \\
\text { IVIG }\end{array}$ & $\begin{array}{c}\text { EDSS } \\
\text { pēc IVIG } \\
\text { (laiks } \\
\text { starp Tx } \\
\text { un } \\
\text { nākamo } \\
\text { paasin.) }\end{array}$ & $\begin{array}{l}\text { Obj. } \\
\text { f-ju } \\
\text { uzlabo- } \\
\text { šanās }\end{array}$ & $\begin{array}{l}\text { Blak- } \\
\text { nes }\end{array}$ \\
\hline $\begin{array}{l}9 . \\
24, S\end{array}$ & $\begin{array}{l}\text { NMO } \\
\text { (abpusējs } \\
\text { ON, GU) }\end{array}$ & - & $\begin{array}{l}3 \text { (labajā } \\
\text { acī GU, } \\
\text { kreisajā } \\
6 / 18)\end{array}$ & $\begin{array}{l}\text { Mito- } \\
\text { ksantrons, } \\
\text { pred. }\end{array}$ & $\begin{array}{l}\text { IVMP, } \\
\text { PLEX }\end{array}$ & $\begin{array}{l}\text { Nav } \\
\text { uzlabošanās } \\
\text { no IVMP } \\
\text { un PLEX }\end{array}$ & Pred. & 4 & $\begin{array}{l}3 \\
\text { (4 mēn.) }\end{array}$ & $\mathrm{Jā}$ & $\begin{array}{l}\text { Izteiktas } \\
\text { galvas- } \\
\text { sāpes ar } \\
\text { pavadošu } \\
\text { vemšanu, } \\
\text { bezmiegu } \\
\text { un } \\
\text { spontānu } \\
\text { remisiju } \\
\text { dažu } \\
\text { stundu } \\
\text { laikā }\end{array}$ \\
\hline $\begin{array}{l}10.1 \\
* \\
7, \mathrm{~S}\end{array}$ & $\begin{array}{l}\text { NMO } \\
\text { (abpusējs } \\
\text { ON, GU) }\end{array}$ & - & $\begin{array}{l}\text { Nav } \\
\text { (pirmā } \\
\text { klīniskā } \\
\text { epizode) }\end{array}$ & $\begin{array}{l}\text { PLEX ik } \\
\text { pa } \\
2 \text { nedēl̄ām } \\
\text { hemolītiski } \\
\text { urēmiskā } \\
\text { sindroma } \\
\text { ārstēšanai }\end{array}$ & $\begin{array}{l}\text { IVMP, } \\
\text { PLEX }\end{array}$ & $\begin{array}{l}\text { Nav } \\
\text { uzlabošanās } \\
\text { no IVMP } \\
\text { un PLEX }\end{array}$ & Pred. & 4 & $\begin{array}{l}4 \\
\text { (1 mēn.) }\end{array}$ & $\mathrm{Nē}$ & $\mathrm{Nav}$ \\
\hline
\end{tabular}


2.6. tabulas nobeigums

\begin{tabular}{|c|c|c|c|c|c|c|c|c|c|c|c|}
\hline $\begin{array}{l}\text { Nr. } \\
\text { p.k., } \\
\text { vec./ } \\
\text { Dz. }\end{array}$ & $\begin{array}{l}\text { Ar IVIG } \\
\text { ārstētā P } \\
\text { fenotips) }\end{array}$ & $\begin{array}{c}\text { AQP4- } \\
\text { IgG }\end{array}$ & $\begin{array}{c}\text { EDSS } \\
\text { (f-ju } \\
\text { deficīts } \\
\text { pirms esošā } \\
\text { paasin.) }\end{array}$ & $\begin{array}{l}\text { IST pirms } \\
\text { IVIG }\end{array}$ & $\begin{array}{c}\text { Akūtā } \\
\text { perioda } \\
\text { ārstēša } \\
\text { na } \\
\text { pirms } \\
\text { IVIG }\end{array}$ & $\begin{array}{l}\text { Indikācija } \\
\text { IVIG }\end{array}$ & $\begin{array}{c}\text { Saņemtā } \\
\text { Tx pēc } \\
\text { IVIG }\end{array}$ & $\begin{array}{l}\text { EDSS } \\
\text { pirms } \\
\text { IVIG }\end{array}$ & $\begin{array}{c}\text { EDSS } \\
\text { pēc IVIG } \\
\text { (laiks } \\
\text { starp Tx } \\
\text { un } \\
\text { nākamo } \\
\text { paasin.) } \\
\end{array}$ & $\begin{array}{c}\text { Obj. } \\
\text { f-ju } \\
\text { uzlabo- } \\
\text { šanās }\end{array}$ & $\begin{array}{c}\text { Blak- } \\
\text { nes }\end{array}$ \\
\hline $\begin{array}{l}10.2 \\
* \\
7, \mathrm{~S}\end{array}$ & $\begin{array}{l}\text { NMO } \\
\text { (cervikāls } \\
\text { LM, } \\
\text { muskulu } \\
\text { spēks rokās } \\
\text { un kājās } \\
\text { MRC 0/5) }\end{array}$ & - & $\begin{array}{l}4 \text { (GU } \\
\text { abpusēji) }\end{array}$ & & $\begin{array}{l}\text { IVMP } \\
\text { turpinot } \\
\text { ar pred., } \\
\text { PLEX }\end{array}$ & $\begin{array}{l}\text { Nav } \\
\text { uzlabošanās } \\
\text { no IVMP } \\
\text { un PLEX }\end{array}$ & Pred. & 9 & $\begin{array}{l}9 \\
\text { (1 mēn.) }\end{array}$ & $\mathrm{Ne \overline { }}$ & $\mathrm{Nav}$ \\
\hline
\end{tabular}

IVIG - intravenozi imūnglobulīni, GU-gaismas uztvere, NGU - piln̄̄gs aklums, gaismas uztvere nav iespējama, p/o - perorāli, PLEX - plazmaferēze, IVMP - metilprednizolons intravenozi, NMO - optiskais neiromielīts, LM - longitudināls mielīts, S - sieviete, V - vīrietis, ON - optisks neirīts, KS - kortikosteroīdi, MRC - medicīnas zinātniskās padomes vērtējuma sistēma, P - paasinājums, Dz. - dzimums, Tx - terapija, f-ju - funkciju, obj. - objektīva, IST - imūnsupresīva terapija, pred. - p/o prednizolons, NZ - nav zināms, mēn. - mēnesis 
Pacienti ar $\leq 2$ paasinājumiem pēdējo 6 mēnešu vai 3 paasinājumiem pēdējo 12 mēnešu laikāa $(n=67)$.

Mazāk nekā 2 paasinājumus pēdējo 6 mēnešu laikā vai 3 paasinājumus pēdējo 12 mēnešu laikā novēroja 67 pētījuma slimniekiem (mazāk aktīva slimības norise jeb MANMO); demogrāfiskos rādītājus un vispārējo slimības raksturojumu skat. 2.7. tabulā. RSG samazinājums bija nozīmīgāks nekā ANMO pacientiem $(\mathrm{p}=0,0025)$. Arī mediānais laika periods līdz pirmajam un otrajam recidīvam, salīdzinot ar ANMO, bija ilgāks ( $\mathrm{p}=0,03$ un $\mathrm{p}=0,0097$ ), respektīvi, 52 (30) un 176 (62) mēneši attiecībā pret 24 un 84 mēnešiem (skat. 2.2. attēlu).

2.7. tabula

Vispārējs pacientu un ārstēšanas efektivitātes raksturojums pa grupām

\begin{tabular}{|l|l|l|}
\hline \multicolumn{1}{|c|}{ Rādītāji } & ANMO $(\mathrm{N}=36)$ & MANMO $(\mathrm{N}=67)$ \\
\hline $\begin{array}{l}\text { Dzimums: Sievietes } \\
\text { Vīrieši }\end{array}$ & $\begin{array}{l}33(92 \%) \\
3(8 \%)\end{array}$ & $\begin{array}{l}58(87 \%) \\
9(13 \%)\end{array}$ \\
\hline $\begin{array}{l}\text { Mediānais vecums, uzsākot AZA, } \\
\text { gadi }\end{array}$ & $39,9(3,7-75,8)$ & $50,1(17,2-79)$ \\
\hline $\begin{array}{l}\text { Mediānais vecums pēdējā } \\
\text { novērošanas vizītē, gadi }\end{array}$ & $45(5-77)$ & $52(18-80)$ \\
\hline $\begin{array}{l}\text { Mediānais slimības ilgums, } \\
\text { uzsākot AZA, gadi }\end{array}$ & $1(0,08-14,42)$ & $43\left(0-31,47^{*}\right)$ mēneši \\
\hline $\begin{array}{l}\text { AZA kā pirmās līnijas } \\
\text { medikaments }\end{array}$ & $27 / 36(75 \%)$ & $63 / 67(94 \%)$ \\
\hline $\begin{array}{l}\text { Mediānais AZA lietošanas ilgums } \\
\text { (mēneši) }\end{array}$ & $22(0,03-256)$ & $17(0,01-254)$ \\
\hline Mediānā AZA deva, mg dienā & $100(25-250)$ & $150(25-275)$ \\
\hline Mediānā prednizolona deva (mg) & $5(3,75-40)$ & $2,5(1,25-45)$ \\
\hline $\begin{array}{l}\text { Mediānais kopējais recidīvu } \\
\text { skaits pirms AZA }\end{array}$ & $4(2-12)$ & $2(0-22)^{*}$ \\
\hline $\begin{array}{l}\text { Mediānais recid̄̄ivu skaits 12 } \\
\text { mēnešus pirms AZA }\end{array}$ & $3(2-5)$ & $1(0-12)^{*}$ \\
\hline
\end{tabular}


2.7. tabulas nobeigums

\begin{tabular}{|l|l|l|}
\hline Rādītāji & ANMO $(\mathrm{N}=36)$ & MANMO (N = 67) \\
\hline $\begin{array}{l}\text { Mediānais recidīvu skaits gadā (RSG) } \\
\text { pirms AZA, kopējais }\end{array}$ & $3,8(0,28-12)$ & $1(0,06-25)$ \\
pirms AZA (novērošanas periods $\geq 12$ & $3,6(0,28-8)$ & - \\
mēneši) & $3(0,6-6,9)$ & $1(0,2-12)$ \\
12 mēnešus pirms AZA & $0,21(0-6,67)$ & - \\
saņemot AZA (kopējā grupā) & $0,27(0-156 ;$ & \\
saņemot AZA (novērošanas periods & $\mathrm{IQR} 0-0,84)$ & 6 \\
$\geq 12$ mēneši) & 5,5 & $6(\mathrm{p}=0,59)$ \\
\hline $\begin{array}{l}\text { Mediānais EDSS } \\
\text { pirms AZA }\end{array}$ & $4,5(\mathrm{p}=0,35)$ & $75(50 / 67)$ \\
pēc AZA & 86 & 70 \\
Neiroloǵiskās funkcijas stabilizācija & & 52 \\
vai uzlabošanās, \% & 44 & 176 \\
\hline Klīniska remisija, \% & 24 & \\
\hline $\begin{array}{l}\text { Mediānais laiks līdz pirmajam } \\
\text { recidīvam, mēneši }\end{array}$ & 84 & \\
\hline $\begin{array}{l}\text { Mediānais laiks līdz otrajam } \\
\text { recidīvam, mēneši }\end{array}$ & & \\
\hline
\end{tabular}

*2 pacienti sāka AZA pirms NMO sākuma

IST - imūnsupresīva terapija, AZA - azatioprīns, EDSS - izvērstā invaliditātes skala, ANMO - NMO ar izteiktu slimības aktivitāti (biežiem paasinājumiem), MANMO mazāk aktīvs NMO 


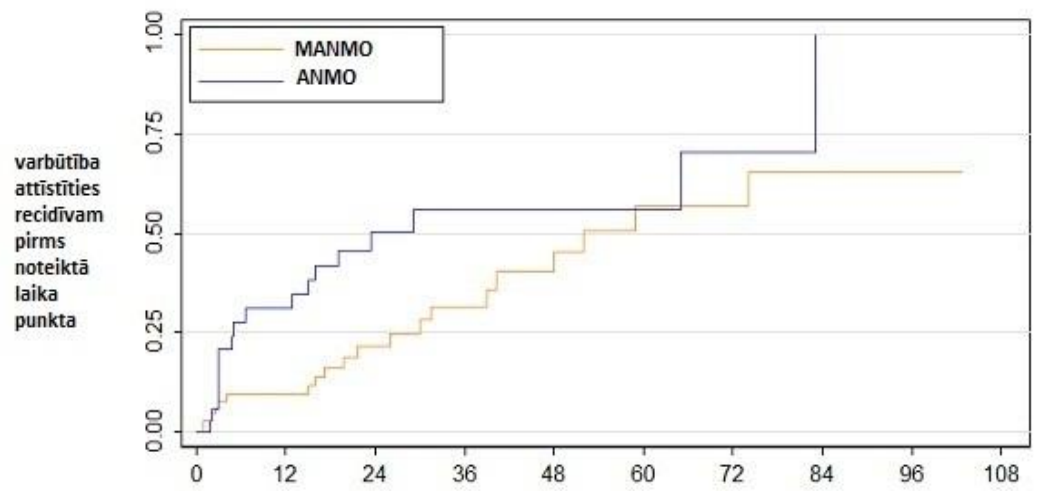

slimnieku skaits

LAIKS LĪDZ PIRMAJAM RECIDĨVAM (MĒNEŠI)

$\begin{array}{llllllllllllllllllll}\text { MANMO } & 67 & (6) & 46 & (5) & 27 & (3) & 16 & (2) & 12 & (3) & 7 & (0) & 5 & (1) & 4 & (0) & 4 & (0) & 3 \\ \text { ANMO } & 36 & (10) & 20 & (5) & 10 & (1) & 8 & (0) & 6 & (0) & 3 & (2) & 1 & (0) & 0 & (0) & 0 & (0) & 0\end{array}$
ANMO

(5) 10 (1) 8

(0) 6

(0) 3

(2) 1

(0) 0

(0) 0 (0) 0

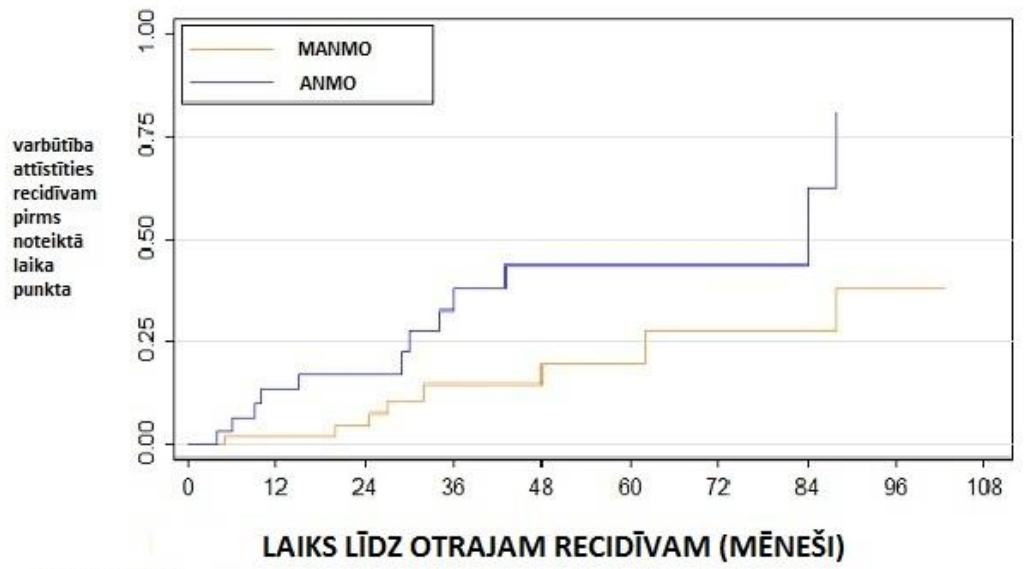

slimnieku skaits

$\begin{array}{llllllllllllllllllll}\text { MANMO } & 67 & (1) & 51 & (1) & 33 & (3) & 21 & (0) & 17 & (1) & 11 & (1) & 7 & (0) & 7 & (1) & 5 & (0) & 4 \\ \text { ANMO } & 36 & (4) & 25 & (1) & 17 & (3) & 13 & (2) & 9 & (0) & 4 & (0) & 3 & (0) & 3 & (2) & 1 & (0) & 1\end{array}$

2.2. attēls. Kaplana-Maijera līkne. Varbūtība, ka pacientiem, kas saṇem AZA, attīstīsies pirmais un otrais paasinājums laika gaitā 


\section{Pacienti ar izteiktiem funkciju traucējumiem pirms ārstēšanas}

$\operatorname{period} \bar{a}(n=63)$

Izteiktu funkciju deficītu 6 mēnešu laikā pirms AZA uzsākšanas jeb maksimālo vai reziduālo neirolog̣isko funkciju deficītu, kas vērtējams ar EDSS pakāpi $\geq 6$ (pārvietojas ar vienpusēju atbalstu) mielīta gadījumā un/vai EDSS pakāpi $\geq 3$ (vizuālā skala $\geq 4$ ar maksimālo redzes asumu 6/36-6/60 sliktākajā acī) redzes nerva neirīta gadījumā, novēroja 62 pētījuma slimniekiem.

$35(57 \%)$ no tiem klīniski atbilda NMO fenotipam, pārējiem novēroja izolētu TM vai ON (vairumam recidivējošu): 15 (23,8\%) recidivējošs TM, $4(6,3 \%)$ recidivējošs $\mathrm{ON}$ un $8(12,7 \%)$ monofāzisks TM. To mediānais slimības ilgums bija 20 un AZA ārstēšanas ilgums - 17,5 (0,02-256) mēneši. Mediānā AZA deva bija 150 (25-275) mg dienā. 39/63 (62\%) papildus saṇēma prednizolonu - 5 (1,25-45) mg dienā.

Ārstēšanas rezultātā 66\% (41/62) novēroja klīnisku remisiju. Mediānais RSG samazinājās no 1,7 uz 0 . Atlikušajiem 21 pacientam kopā reǵistrēti 66 paasinājumi. 15\% (10/66) no visiem paasinājumiem (9 pacientiem) izpaudās ārstēšanas pirmo 6 mēnešu laikā. Mediānais laiks līdz pirmajam paasinājumam bija 67 (IQR 17,.) mēneši. Neviens no 21 pacientiem ārstēšanu pēc pirmā recidīva nepārtrauca un $71 \%$ novēroja atkārtotu recidīvu mediāni 5 (2-172) mēnešus vēlāk. Neirologiskāa funkcija (pēc EDSS) saglabājās relatīvi nemainīga.

\subsubsection{Efektivitātes raksturojums: invaliditāte jeb funkciju zudums}

Neirologiisko funkciju (pēc EDSS) bija iespējams izvērtēt 96/103 pacientu. 62\% (59/96) tā saglabājās nemainīga, 23\% (22/96) - vērojams funkciju uzlabojums par mediāni $2(1-4,5)$ EDSS punktiem $(\mathrm{p}=0,02)$, bet $16 \%$ (15/96) - pasliktinājums. Kopumā bija fiksēts EDSS uzlabojums, mediāni no 6 (IQR 3,5-6,5) uz 5 (IQR 3,5-6,5). Visiem pacientiem, izñemot 2, (tiem novēroja izteiktu funkciju pasliktinājumu), kas iepriekš bija saņēmuši citu imūnsupresīvu terapiju, EDSS vērtība saglabājās nemainīga. Pēc mirušo ( $\mathrm{n}=9$, EDSS $=10$ ) pacientu izslēgšanas no aprēķina, vēroja EDSS samazinājumu no 5,5 (IQR 3,5-6,5) uz 4,0 (IQR 3,5-6,0), p = 0,03. EDSS stabilizāciju vai funkciju uzlabošanos reǵistrēja ar̄̄ 86\% (31/36) NMO gadījumos ar izteiktāku slimības aktivitāti (ANMO). 


\subsubsection{4. Ārstēšanas nepārtrauktība}

Uzskaitot visus gadījumus, mediānais ārstēšanas ilgums ar AZA bija 18 (0,01-256) mēneši. Pēdējā novērošanas vizìtē medikamentu turpināja 54\% (56/103) slimnieku. 23\% $(\mathrm{n}=24)$ pacientu ārstēšanu pārtrauca pirmo 6 mēnešu laikā, pārējie (n = 72) - AZA turpināja mediāni 31,5 (7-256) mēnešus. Ārstēšana tika pārtraukta: $62 \%(\mathrm{n}=29)$ blakņu, $19 \%(\mathrm{n}=9)$ exitus letalis, $15 \%$ $(\mathrm{n}=7)$ paasinājumu, $2 \%(\mathrm{n}=1)$ grūtniecības dēḷ. Pārtraukšanas iemesls nebija precizēts vienā gadījumā (2\%). AZA lietošanu blakṇu dēḷ pārtrauca mediāni 2 mēnešos, kas bija daudz agrāk, salīdzinot ar 16 mēnešiem (mediāni pēc 3 paasinājumiem) slimības aktivitātes dēḷ. Izvērtējot AZA pārtraukšanas laiku dažādās apakšgrupās (ANMO, MANMO, SNNMO), statistiski nozīmīgas atšksirības starp grupām, kā arī to dažādām kombinācijām netika novērotas $(\mathrm{p}=0,48, \mathrm{p}=0,956)$. Starp pacientiem, kas AZA saṇēma vismaz 6 mēnešus (izslēdzot pacientus, kas AZA pārtrauca agrīni vai līdz iekḷaušanai pētījumā saņēma medikamentu mazāk nekā 6 mēnešus), mediānais ārstēšanas ilgums bija 31,5 (7-256) mēneši.

Blakusefekti, ko novēroja $60 \%$ (62/103) pacientu, bija vadošais $(62 \%$, 29/47) iemesls AZA pārtraukšanai. 24,3\% (n = 25) attīstījās gastrointestināli traucējumi, 23,3\% ( $\mathrm{n}=24)$ - hematoloǵiski traucējumi, 5,8\% (n=6)kardiorespiratori traucējumi, 2,9\% $(\mathrm{n}=3)$ - infekcijas, 7,8\%(8) - cita veida traucējumi. Gastrointestinālu traucējumu dēl AZA pārtrauca 72\% (n = 18), hematologisku traucējumu - 33\% ( $\mathrm{n}=8)$, infekciju - 33\% ( $=1)$, citu blakņu dēl $-75 \%(n=6)$. Ar detalizētāku blakṇu sarakstu var iepazīties promocijas darba pilnajā versijā.

Analizējot mirušo pacientu datus, nozīmīgi funkcionāli traucējumi jau pirms terapijas sākuma (mediānais EDSS 7,5 (6-8)) bija fiksēti visiem pacientiem. To mediānais AZA lietošanas ilgums bija 31 (2-256) mēneši un slimības ilgums $6,25(0,47-32,5)$ gadi. Nāves cēlonis bija zināms 5/9 slimniekiem: 1 - sepse, 1 - sirds mazspēja un plaušu embolisms, 3 - pneimonija, 1 - miokarda infarkts.

Varbūtība turpināt AZA laika gaitā (2.3. attēls) tika novērtēta, izmantojot Kaplana-Maijera analīzi. Pētījumā rezultātā aprēḳināts, ka varbūtība, ka pacienti turpinās lietot AZA vismaz 1 gadu ir $73 \%$ (95\% TI: 63,81), vismaz 3 gadus - 58\% (95\% TI: 47,68), vismaz 5 gadus $-47 \%(95 \%$ TI: 34,59$)$ un vismaz 10 gadus - 33\% (95\% TI: 19,48). 


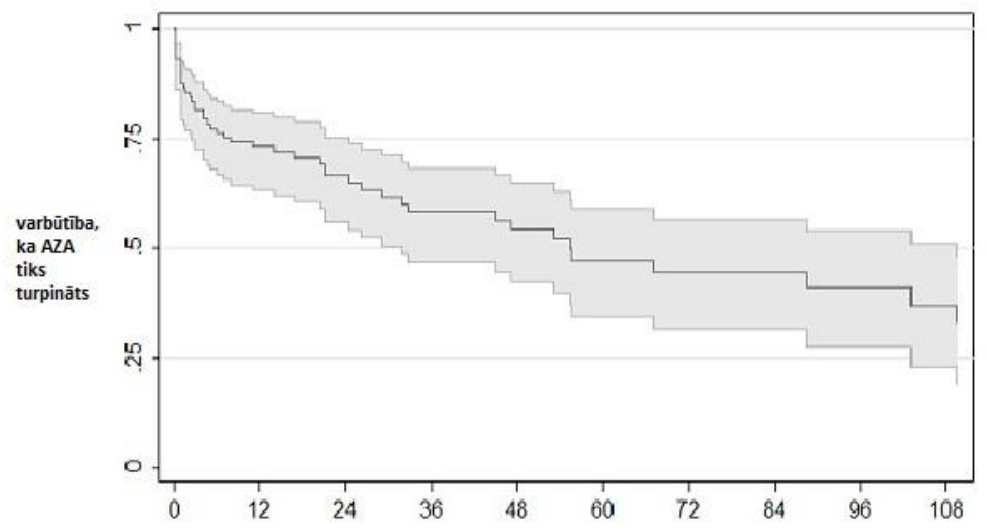

AZA LIETOŠANAS ILGUMS (MĒNEŠI)

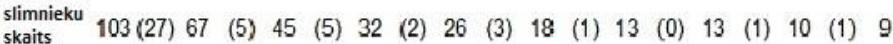

2.3. attēls. Kaplana-Maijera līkne. Varbūtība, ka pacienti turpinās saṇemt AZA (ar 95\% ticamības intervāliem)

\subsubsection{Latvijas MS reǵistrā ievadāmo datu analīze}

\subsubsection{MS reǵistra vispārēja analīze}

2.8. tabula

\begin{tabular}{|l|l|}
\hline \multicolumn{1}{|c|}{$\begin{array}{c}\text { Vērtējamie } \\
\text { parametri }\end{array}$} & \multicolumn{1}{c|}{ Raksturojums } \\
\hline Mērkspopulācija & $\begin{array}{l}\text { Nacionāls reğistrs. Sākotnēji (no 1997. gada) darbojās kā MS } \\
\text { datu bāze - ar piekḷuvi tikai LJMC ietvaros (valsts apmaksāta } \\
\text { programma); pacienti tika nosūtīti no visas Latvijas. }\end{array}$ \\
\hline $\begin{array}{l}\text { Minimāls } \\
\text { standartizētu datu } \\
\text { apjoms }\end{array}$ & $\begin{array}{l}\text { Pēc Latvijas MS pacienta kartes (Ministru Kabineta 2008. } \\
\text { gada 15. septembra noteikumi Nr. 746; 13. pielikums), kurā } \\
\text { izmantoti standartizēti parametri, starptautiska nomenklatūra. }\end{array}$ \\
\hline
\end{tabular}


2.8. tabulas nobeigums

\begin{tabular}{|c|c|}
\hline $\begin{array}{l}\text { Vērtējamie } \\
\text { parametri }\end{array}$ & Raksturojums \\
\hline $\begin{array}{l}\text { Datu aizsardzība, } \\
\text { konfidencionalitāte }\end{array}$ & $\begin{array}{l}\text { Atbildīgā institūcija - SPKC (normatīvo pamatojumu nodrošina } \\
\text { 15.09.2008. MK noteikumi Nr.746 “Ar noteiktām slimībām } \\
\text { slimojošu pacientu reǵistra izveides, papildināšanas un } \\
\text { uzturēšanas kārtība”); personu datu operators - joprojām LJMC. } \\
\text { Iespēja ievadīt datus - uz iepriekšēja iesnieguma pamata. } \\
\text { Piekḷuve datiem stingri kontrolēta un ierobežota; individualizēta } \\
\text { drošības piekļuves sistēma, datu apjoms atbilstošs katras } \\
\text { personas funkcijām. Konfidencionalitāte nodrošināta atbilstoši } \\
\text { likumdošanā noteiktām normām (Fizisko personu datu } \\
\text { aizsardzības likums). }\end{array}$ \\
\hline $\begin{array}{l}\text { Reǵistra tehniskais } \\
\text { nodrošinājums }\end{array}$ & $\begin{array}{l}\text { No MS kartes datus ievada sistēmā; datus var ievadīt un } \\
\text { aktualizēt sistēmā arī centralizēti - tiešsaistes režīmā. }\end{array}$ \\
\hline $\begin{array}{l}\text { Ētikas } \\
\text { pamatprincipu } \\
\text { ievērošana }\end{array}$ & $\begin{array}{l}\text { Pacientu rakstiska piekrišana un informēšana par to datu ievadi } \\
\text { reǵistrā nav prasīta. }\end{array}$ \\
\hline $\begin{array}{l}\text { Paziņošanas } \\
\text { kārtība un datu } \\
\text { kvalitātes kontrole }\end{array}$ & $\begin{array}{l}\text { Personu apmācība par datu ievadi notiek pašmācības cel̦ā, } \\
\text { iepazīstoties ar MS pacienta kartes datu ievades instrukciju. } \\
\text { Datu reǵistrēšana sistēmā notiek pēc godprātības principa. } \\
\text { Kontroles mehānismi praksē nedarbojas. }\end{array}$ \\
\hline $\begin{array}{l}\text { Sistēmas } \\
\text { nepārtrauktība }\end{array}$ & Reǵistra darbību nodrošina stabils nepārtraukts finansējums. \\
\hline $\begin{array}{l}\text { Iespēja operēt ar } \\
\text { iegūtajiem datiem, } \\
\text { datu lietderīgums }\end{array}$ & $\begin{array}{l}\text { Tieša piekluve datiem nodrošināta SPKC atbildīgiem } \\
\text { darbiniekiem, kā arī datu operatoram-LJMC. Informācija par } \\
\text { pieteikšanās kārtību datu izmantošanai zinātniskiem mērksiem } \\
\text { publiski nav pieejama. Šobrīd ir spēkā esoša MS karte, kuras } \\
\text { pamatizstrāde veikta jau tālajā 1997. gadā un MK noteikumos } \\
\text { apstiprināta 2008. gadā. Ievadāmo datu moduḷu pārskatīšana un } \\
\text { aktualizēšana atbilstoši mūsdienu aktualitātēm nav veikta. }\end{array}$ \\
\hline
\end{tabular}

\subsubsection{Iespēja atklāt NMO un citu retu slimību variantus vai atipiskus simptomus}

Datu modulis par MS anamnēzi nodrošina slimības simptomu detalizētu uzskaitījumu. Tas ietver arī klasifikāciju pēc slimības formas (cerebrālā, cerebrospinālā, spinālā) un norises. 
Sākotnējā MS pacientu datu bāze (LJMC), kā arī datu karte paredz apkopot datus par citiem DS (ne MS) gadījumiem, respektīvi B grupu (aizdomu MS) un C grupu (apstiprināta cita ticamāka saslimšana), tomēr praksē tas tā nenotiek. Latvijas MS reǵistra analīzes kopsavilkums attiecībā uz potenciālu NMO gadījumu retrospektīvu atklāšanu pēc klīniskiem anamnēzes datiem, laboratoriskiem un MR rezultātiem atspogulsots 2.9. tabulā.

2.9. tabula

Latvijas MS reǵistra analīze pēc NMO raksturojošām pazīmēm

\begin{tabular}{|c|c|c|}
\hline $\begin{array}{l}\text { Vadošie } \\
\text { parametri }\end{array}$ & Raksturojošā pazīme & Atradne \\
\hline \multirow{4}{*}{$\begin{array}{l}\text { Klīniskie } \\
\text { anamnēzes dati }\end{array}$} & Saslimšanas vecums & Ir nosakāms \\
\hline & $\begin{array}{l}\text { Recidīvu raksturojums: } \\
\text { - anatomiskā lokalizācija } \\
\text { - izteiktības pakāpe } \\
\text { - iznākums }\end{array}$ & $\begin{array}{l}\text { Daḷēji nosakāms } \\
\text { nav nosakāms } \\
\text { nav nosakāms }\end{array}$ \\
\hline & $\begin{array}{l}\text { Specifisku klīnisko simptomu } \\
\text { esamība/neesamība }\end{array}$ & Ir iespēja uzskaitīt \\
\hline & $\begin{array}{l}\text { Saṇemtās ārstēšanas efektivitāte } \\
\text { (slimības stabilizācija/ pasliktināšanās / } \\
\text { bez izmain̄ām) }\end{array}$ & Nav nosakāms \\
\hline $\begin{array}{l}\text { Laboratoriskie } \\
\text { dati }\end{array}$ & $\begin{array}{l}\text { Blakus saslimšanu anamnēze (citas } \\
\text { autoimūnas saslimšanas) }\end{array}$ & Ir iespēja uzskaitīt \\
\hline \multirow[t]{3}{*}{ MR atradne } & Perēkḷu lokalizācija galvas smadzenēs & Nav nosakāms \\
\hline & Perēkḷu lokalizācija muguras smadzenēs & Nav nosakāms \\
\hline & $\begin{array}{l}\text { Perēkḷu raksturojums muguras } \\
\text { smadzenēs (vai ir iespējams noteikt } \\
\text { perēkḷu garumu?) }\end{array}$ & Nav nosakāms \\
\hline
\end{tabular}




\section{DISKUSIJA}

\subsection{Optiskā neiromielīta klīniskais raksturojums}

\subsubsection{Paasinājumu sezonalitāte}

Vairumā gadījumu NMO izpaužas ar recidīviem, radot izteiktu neatgriezenisku neirologisko funkciju zudumu. Vidējais paasinājumu skaits gadā ir 0,82 (Kitley, Leite et al. 2012). Lai gan izraisošie faktori joprojām nav noskaidroti, NMO/NMOS recidīvi visticamāk ir kā sekas imūnu reakciju kaskādei, kuras rezultātā rodas iekaisums centrālā nervu sistēmā ar tam sekojošu klīnisku pasliktināšanos. Ārējās vides loma MS u. c. iekaisīgu saslimšanu patoǵenēzē pētīta jau vairākas dekādes. Ir novērots, ka MS aktivitāte un izplatība pieaug, attālinoties no ekvatora. Pētnieki to izskaidro ar solārās aktivitātes un D vitamīna sintēzes lomu MS etiopatoǵenēzē (Handel, Giovannoni et al. 2010, Handel, Handunnetthi et al. 2010, Spelman, Gray et al. 2014). Interesants ir fakts, ka neskatoties uz ultravioleto staru imūnsupresīvo darbību, Ziemel̦u puslodes indivīdiem ar MS vai ON augstākā saslimstība un slimības aktivitāte novērota "siltajos" mēnešos (ar dažām variācijām atšksirīgos gados). Atsevišķi autori ziņo par vairākiem aktivitātes pīķiem vienlaicīgi gan "aukstajos", gan "siltajos" mēnešos (Bamford, Sibley et al. 1983, Jin, de PedroCuesta et al. 2000, Koziol and Feng 2004, Ogawa, Mochizuki et al. 2004, Abella-Corral, Prieto et al. 2005, Fonseca, Costa et al. 2009, Balashov, Pal et al. 2010, Meier, Balashov et al. 2010, Salvi, Bartolomei et al. 2010, Handel, Disanto et al. 2011, Damasceno, Von Glehn et al. 2012, Iuliano 2012, Hart and Gorman 2013, Muto, Mori et al. 2013, Spelman, Gray et al. 2014).

Joprojām nav noskaidrots, vai arī NMO, līdzịgi MS un citām iekaisīgām CNS saslimšanām, kuru aktivitātei ir sezonāls raksturs, izpaužas, mijiedarbojoties ārējās vides un ǵenētiskiem faktoriem. Pašreizējā literatūrā ziņojumi par paasinājumu sezonalitāti NMO slimniekiem rietumu populācijā nav atrodami. Salīdzinoši nesenā pētījumā no Japānas slimības aktivitātē sezonāls raksturs netika novērots (Muto, Mori et al. 2013). Tomēr jāatzīmē, ka tajā pētījumā bija iekḷauti ar̄̄ AQP4-IgG negatīvi slimnieki, kas varēja ietekmēt pētījuma negatīvu rezultātu. Kā zināms, tad Āzijas valstīs prevalējoši dominē optikospināla MS, kuras atdiferencēšana no NMO ne vienmēr ir vienprātīga.

Šis ir pirmais pêtījums, kurš ziņo par NMO sezonalitāti rietumu populācijā un reprezentē datus no Apvienotās Karalistes. Lai izvairītos no 
diagnostiskām kḷūdām, pêtījumā iekḷauti dati tikai par AQP4-IgG pozitīviem pacientiem.

Sākotnējā vienkāršotajā analīzē, izdalot paasinājumu skaitu ar 12 jeb mēnešu skaitu gadā, tika noskaidrots, ka salīdzinoši mazāk paasinājumu bija jūnija mēnes̄i (6,6\% pret prognozētajiem $8,33 \%$, paasinājumu proporcijas koeficients - 0,74) un, iespējams, jūlijā $(7,7 \%$, paasinājumu proporcijas koeficients $-0,87$ ), taču gada griezumā - bez statistiski nozīmīgām atšķirīibām ( $\mathrm{p}=0,19$ un 0,52). Tas, iespējams, izskaidrojams ar to, ka blakus esošajos mēnešos (maijā un augustā) vērojamais paasinājumu skaits bija nedaudz augstāks. Savukārt, izmantojot loǵistisko regresiju, nedaudz augstāks paasinājumu skaits bija oktobra $(\mathrm{p}=0,04)$ un novembra $(\mathrm{p}=0,007)$ mēnešos. Interesants ir fakts, ka šì pētījuma rezultāti, demonstrējot paaugstinātu slimības aktivitāti tieši "aukstajos mēnešos", uzrāda pretēju tendenci kāda novērota MS slimniekiem rietumu populācijā (Koziol and Feng 2004, Fonseca, Costa et al. 2009, Handel, Disanto et al. 2011, Damasceno, Von Glehn et al. 2012). Tomēr jāatzīst, ka, lai gan p vērtība uzrāda statistiski ticamus rezultātus, analizētā pacientu grupa ir salīdzinoši neliela, tādēl̦ rezultāti jāvērtē piesardzīgi. Vienlaikus jāpatur prātā, ka dati no Japānas neuzrādīja NMO paasinājumu sezonālu raksturu. Tas savukārt veicina domāt, ka ārējo faktoru loma, ja vien tāda ir vispār, NMO gadījumā ir atšķirīga no MS. Iespējams, ka NMO fāzē, kad slimība jau ir pilnībā attīstījusies, patoǵenētiskie mehānismi nav sensitīvi pret sezonālām vai ārējo faktoru svārstībām. Šī pētījuma rezultāti, līdzīgi kā citu pētījumu rezultāti par klīniskām, laboratoriskām (citokīni utt.) un radiolog̣iskām īpatnībām, apstiprina hipotēzi, ka NMO un MS ir divas atšķirīgas slimības.

Pētījuma rezultātu interpretāciju ietekmē vairāki faktori. Katrs no pētījumā iesaistītiem centriem pārstāv lokālo terciārās veselības aprūpes centru, uz kuru nosūtāmi pacienti ar NMO, tomēr šis nav uz visu valsts populāciju balstīts pētījums, tādējādi pastāv iespēja, ka tiek nosūti iepriekš selektīvi atlasīti pacienti, kuri neatspogulo visu NMO slimnieku populāciju valstī. Iespējams arī, ka retrospektīvs pētījuma dizains ir ietekmējis rezultātu akurātumu. Jāpiebilst, ka iekḷautie paasinājumi tika apstiprināti galvenokārt klīniski, radiologisks apstiprinājums netika pieprasīts. Paasinājuma datumu (līiz mēneša precizitātei) precizēt nebija iespējams 10\% gadījumu. Vienlaicīgi, nelielā pacientu skaita dēl netika nodalīti un atsevišķi vērtēti paasinājumi pirms un pēc imūnsupresīvas terapijas uzsākšanas, kuras ietekmē kopējais paasinājumu skaits ir mainījies vairumam pacientu. Iespējams arī, ka kāds no paasinājumiem netika ieskaitīts, 
jo gadījumos, kad jaunu simptomu vai iepriekšējo simptomu būtiska pasliktināšanās bija vērojama tikai ar 30-60 dienu starpību, tie tika uzskatīit par vienu paasinājumu, respektīvi, kā iepriekšējā paasinājuma turpinājums nevis 2 atšķirīgi.

Ņemot vērā NMO recidīvu potenciālo komplikāciju smagumu, ir nepieciešami turpmāki prospektīivi pētījumi, kas, iespējams, palīdzētu noskaidrot potenciālos mehānismus, kas ir paasinājumu rašanās pamatā, tādējādi ietekmējot jaunu terapijas virzienu attīstību.

\subsubsection{Pirmās klīniskās epizodes īpatnības}

Vairākus gadu desmitus NMO uzskatīja par akūtu monofāzisku optikospinālas demielinizācijas sindromu, un vēl salīdzinoši nesen literatūrā bija aprakstīti tikai daži NMO slimības gadījumi. Zināšanas un izpratne par to krasi mainījās 1999. gadā, kad Vingerčuks pirmo reizi definēja NMO diagnostiskos kritērijus (Wingerchuk, Hogancamp et al. 1999) un sniedza plašāku gadījumu raksturojumu, un atkārtoti - 2004. gadā, kad vairāku šo pacientu serumā atklāja specifiskas antivielas - NMO-IgG (Lennon, Wingerchuk et al. 2004), kas izrādījās unikālas tieši NMO slimniekiem. Vidējais NMO saslimšanas sākums ir 40-50 gadu vecumā, nereti pat pārsniedzot 50 gadu slieksni (Collongues, Marignier et al. 2013). Pēc sākotnējā ziņojuma datiem, kur analizētas NMO klīniskās īpatnības 71 pacientam, PKE laikā novēroja: vienpusēju ON - 26\% slimnieku ar monofāzisku un $48 \%$ ar recidivējošu slimības norisi, abpusēju ON - 17\% ar monofāzisku un $8 \%$ ar recidivējošu $\mathrm{NMO}$, bet $\mathrm{TM}-22 \%$ ar monofāzisku un $48 \%$ ar recidivējošu NMO (Wingerchuk, Hogancamp et al. 1999).

Šajā pētījumā raksturotais NMO/NMOS slimnieku skaits ir viens no lielākajiem, kāds sastopams literatūrā. PKE fenotips (vairumam pacientu manifestējās kā mielīts), tās izteiktības pakāpe un novērotais laika intervāls līdz pirmajam recidīvam neatšķīnās no citu autoru ziņojumiem (Bichuetti, Oliveira et al. 2009, Cabrera-Gomez, Bonnan et al. 2009, Collongues, Marignier et al. 2010, Jarius, Ruprecht et al. 2012) (Wingerchuk, Hogancamp et al. 1999, Bichuetti, Oliveira et al. 2009, Bizzoco, Lolli et al. 2009, Collongues, Marignier et al. 2010, Asgari, Lillevang et al. 2011). Vienlaicīgs redzes un muguras smadzeņu bojājums, līdzīgi kā iepriekšējos ziņojumos, biežāk bija novērojams AQP4-IgG negatīviem pacientiem (29\% salīdzinot ar 5\%) (Jarius, Ruprecht et al. 2012). 
Literatūrā ir aprakstīts arī AQP4-IgG pozitīvs klīniskais gadījums ar sākotnējo simptomu (mielīta) attīstību progresējoši vairāku mēnešu garumā (Woo, Chiu et al. 2014). Progresējoši noritošu sākotnējo simptomu biežums nav zināms. Šis ir pirmais pêtījums, kurā raksturots laika intervāls no PKE pirmo simptomu sākuma līdz to izteiktības maksimumam. Pētījuma rezultātā noskaidrots, ka akūtu simptomu attīstību dažu stundu līdz dienu laikā novēro tikai apmēram pusei pacientu, pārējos gadījumos tā var ieilgt pat vairāku mēnešu garumā, raksturojot progresējošu (subakūtu vai hroniski noritošu) NMO sākumu. Vienā gadījumā sākotnējo simptomu attīstība noritēja progresējoši aptuveni 18 mēnešu garumā. N̦emot vērā to, ka AQP4-IgG antivielas šim slimniekam ir negatīvas, MS diagnoze joprojām ir iespējama, tomēr jāatzīmē, ka, pēc klīniskām un radiologiiskām pazīmēm viņš atbilda NMO diagnostiskiem kritērijiem (Wingerchuk, Lennon et al. 2006).

Iespējams, progresējošu NMO/NMOS sastop daudz biežāk, daudzi em līdzīgiem gadījumiem maskējoties aiz progresējošas mielopātijas, MS u. c. Patoǵenētiskos procesus šādiem progresējošiem gadījumiem ir grūti izskaidrot, taču, iespējams, arī NMO patoǵenēzē, līdzīgi kā MS, vienlīdz nozīmīgi ir gan iekaisīgi, gan deǵeneratīvi procesi. Varētu argumentēt un uzskatīt, ka šie progresējošie gadījumi nav NMO, tomēr AQP4-IgG antivielas, kas ir ļoti specifisks NMO biomarķieris, bija nosakāmas 68\% (15/22) gadījumu.

Šì pētījuma rezultātu interpretēšanu ierobežo galvenokārt tā retrospektīvs dizains; nereti informācija iegūta vairākus gadus pēc saslimšanas sākuma. Tos ietekmē arī citi ierobežojošie faktori, kas ir raksturīgi novērošanas pētījumam, kur darba materiāls ir gadījumu sērija ar nelielu slimnieku skaitu: pacientu atlase rada selekcijas novirzi, nejaušas sakritības iespēja, nav salīdzinošās kontroles grupas.

\subsubsection{Sekundāri progresīva norise}

80-90\% NMO ir raksturīga recidivējoši remitējoša norise. Slimības iznākums ir atkarīgs no paasinājumu skaita un biežuma, neirologisko funkciju deficītam akumulējoties ar katru nākamo recidīvu. Tikai 10-20\% slimnieku novēro monofāzisku norisi un turpmāku klīnisku remisiju.

Par sekundāri progresīvu norisi NMO slimniekiem ir tikai viens ziņojums pirms 8 gadiem, kurā SPNMO novēroja 2\% (2 no 95) gadījumu (Wingerchuk, Pittock et al. 2007). Šajā pētījumā reǵistrētais SPNMO slimnieku skaits bija līdzīgs (4\%). Niecīgais procentuālais NMO slimnieku skaits ar SP 
norisi ir, iespējams, saistīts ar lielāku vidējo saslimšanas vecumu un sliktākiem dzīvildzes rādītājiem, kas nereti ir krietni īsāka par vidējo laika periodu līdz SP norises sākumam slimniekiem ar MS (16 gadi). Interesants ir fakts, ka SP norise NMO slimniekiem, salīdzinot ar MS (65\% 16 gadu laikā), neskatoties uz biežākiem paasinājumiem un izteiktāku audu bojājumu jeb aksonu zudumu, ir reta parādība (Leray, Yaouanq et al. 2010). Pētījumā iekḷauto pacientu saslimšanas vecums bija samērā atšķirīgs un svārstās no 32 līdz 74 gadiem, bet SP norise visos gadījumos viennozīmīgi bija novērojama pēc 50 gadu sliekšña sasniegšanas. Kopumā periods no slimības sākuma līdz SP norisei bija īsāks (vidēji 6,8 \pm 7gadi) nekā MS gadījumā (vidēji 16 gadi). Gados jaunākiem pacientiem (32 gadi) laiks no saslimšanas sākuma līdz SP norises sākumam bija salīdzinoši garāks (19 un 7 gadi), salīdzinot ar 69, 55 un 74 gadus veciem slimniekiem $(2,7 ; 3,9$ un 1,5 gadi). Iespējams, NMO / NMOS patoǵenēzes procesi, līdzīgi kā MS gadījumā, ietver divas fāzes - iekaisuma un deǵeneratīvo, un jāpiekrīt citiem pētniekiem, ka sekundāra slimības progresija attīstās neatkarīgi no aksonu zuduma pakāpes jeb iepriekšējās paasinājumu aktivitātes (Wingerchuk, Pittock et al. 2007) (Confavreux, Vukusic et al. 2000, Scalfari, Neuhaus et al. 2011).

Pētījumu ierobežojošie faktori: retrospektīvs dizains, gadījumu sērija nav pilnīga gadījumu uzskaite, pacientu atlase rada selekcijas novirzi, nejaušas sakritības iespēja, nav pielīdzinātas salīdzinošās kontroles grupas, kā kontroles grupa izmantota vēsturiskā grupa jeb literatūras dati.

\subsubsection{Neiropātiska nieze}

Nieze (pruritus) ir "nepatīkama ādas sajūta, kas rada nepārvaramu vēlmi pakasīit" un ir raksturīgs dažādu dermatologiisku saslimšanu simptoms, taču var izpausties arī sistēmisku, t. sk. neiroloǵisku, slimību gadījumos. NN ir rets, bet skaidri definēts neirologisks simptoms, kas rodas sinaptiskās vadīšanas traucējumu dēl centrālajā vai perifêrā nervu sistēmā bez ādas kairinātāja jeb bojājuma (pruritogēna) klātbūtnes (Twycross, Greaves et al. 2003, Oaklander 2011, Oaklander 2014). NN var izpausties gan pēcherpētiskas neiralǵijas, mono- un poli- neiropātiju, trigeminālas neiralğijas, traumatiska nervu bojājuma, kompleksa reǵionāla sāpju sindroma, multiplās sklerozes, Kreicfelda-Jakoba slimības, insulta un pat NMO gadījumos (Osterman 1976, Osterman 1979, Yamamoto, Yabuki et al. 1981, Yamamoto, Kawazawa et al. 1989, Koeppel, Bramont et al. 1993, Binder, Koroschetz et al. 2008, Alai, Skinner et al. 2010) (Oaklander 2012). NN nav reta NMO / NMOS pacientu 
problēma, tomēr aprakstīta tikai kā atsevišķ gadījumi (El Otmani, Dany et al. 2015, Wang, Qi et al. 2015). Tās biežums un īpatnības līdz pat šim nebija plašāk atspogulotas.

Pruritoceptīvās niezes patoǵenētisko mehānismu pamatā ir primārs ādas kairinājums pruritogēnu ietekmē, kas izraisa nervu C šķiedru kairinājumu, kas tālāk pa muguras smadzeņu mugurējo saknīti tiek aizvadīts uz ganglija šūnām. Tās savukārt satur gastrīnu atbrīvojošo proteīnu (GAP) u. c., kas iesaistās niezes izrais̄̄šanā. Tiek uzskatīts, ka muguras smadzenēs niezes fiziologiskos procesos iesaistās gan histamīnerğiski, gan nehistamīnergiski neironi (Oaklander 2011, Oaklander 2014). Muguras smadzeņu mugurējie ragi, savukārt, satur neironus, uz kuru virsmas izvietoti GAP, neiromedīna B u. c. receptori, kuru funkcija ir niezes pārvade (Sun and Chen 2007, Sun, Zhao et al. 2009, Su and Ko 2011). Tālāk aferentie impulsi no šiem neironiem pa spinotalāmisko ceḷu caur talāmu nokḷūst smadzeņu garozas somatosensorā zonā. Līdzīgi procesi novērojami arī trigeminālā sensorā sistēmā. Tiek uzskatîts, ka sāpju cel̦iem ir modulējoša ietekme uz niezi, t.i., sāpes niezi nomāc, t.sk. niezošās vietas kasǐšana sniedz atvieglojumu. Lai gan neiropātiskas niezes fizioloǵiskie procesi joprojām nav pilnībā noskaidroti, pētnieki uzskata, ka niezi var izraisīt bojājums jebkurā šo sensoro ceļu posmā nervu sistēmā (Binder, Koroschetz et al. 2008, Jeffry, Kim et al. 2011, Oaklander 2011, Mochizuki and Kakigi 2014, Mochizuki, Рароiи et al. 2014, Oaklander 2014).

MS slimniekiem niezi var izraisīt gan muguras, gan galvas smadzeņu bojājums (Ostermann and Westerberg 1975, Yamamoto, Yabuki et al. 1981, Yamamoto, Kawazawa et al. 1989, Sandyk 1994, Oaklander 2012). NMO mielīta gadījumā NN, visticamāk, izraisa iekaisuma un demielinizācijas procesi, kas skar niezes neironus muguras smadzeņu mugurējos ragos, savukārt smadzeņu stumbra bojājuma gadījumā - trigeminālā nerva spinālo kodolu vai pelēko vielu ap III un IV smadzeņu vēderiņiem (Mochizuki, Tashiro et al. 2003, Liu, Berta et al. 2012, Mochizuki, Papoiu et al. 2014). Interesanti, ka NMO slimniekiem (27,3\%) salīdzinot ar MS (4,5\%) NN bija novērojama daudz biežāk. NN kā pirmo neiroloǵisko simptomu var novērot 6\% MS slimnieku (Matthews 1975). Šajā pētījumā NN kā mielīta sākotnējais simptoms novērota $25 \%$ (3/12) NMO / NMOS gadījumu.

Iespējams, ka NN salīdzinoši augstā sastopamība NMO slimniekiem saistīta ar atšķirīgu spinālo perēkḷu novietojumu. NMO slimniekiem muguras smadzeņu perēkḷi pārsvarā ir lokalizēti centrāli, savukārt MS gadījumos - 
izvietoti perifērijā. Kā zināms, tad muguras smadzeņu mugurējie ragi satur daudz GAP, kā arī neiromedīna B receptorus, kas pilda starpnieka funkciju niezes fiziologiskos procesos ( $\mathrm{Su}$ and $\mathrm{Ko}$ 2011). Iespējams, ka nervaudi, kas iesaistīti niezes patoǵenēzē, ir bagāti ar akvaporīnu 4, kura loma NMO patoǵenēzē ir vispārzināma. Lai to apstiprinātu, ir nepieciešami plašāki salīdzinoši pētījumi.

Agrāk aprakstītajiem MS pacientiem NN sākās pēkšņi, ilga no dažām sekundēm līdz dažām minūtēm, izpaudās labi norobežotā ādas apvidū ar pavadošiem jušanas traucējumiem vai sāpēm (Matthews 1975, Yamamoto, Yabuki et al. 1981). Paroksizmāla nieze šî pētījuma slimniekiem izpaudās līdzīgi.

Jāatzīst, ka šim pētījumam ir savi ierobežojumi. Kā viens no būtiskākajiem ir retrospektīvs dizains (dati iegūti mediāni 64 (4-444) mēnešus pēc NN). Iespējams arī, ka NN, kā neiroloǵisks simptoms, ir nepietiekami atpazīta. Tomēr fakts, ka liela dạ̧a NMO slimnieku paši ziņo par NN esamību, liek domāt par NN un NMO savstarpējo saistību. Citi ierobežojošie faktori: gadījumu sērija nav piln̄̄ga gadījumu uzskaite, pacientu atlase rada selekcijas novirzi, nejaušas sakritības iespēja, nav pielīdzinātas salīdzinošās kontroles grupas.

Jāuzsver, ka NMO, savlaicīgi neārstēts, ir strauji noritoša slimība ar augstu invaliditātes un mirstības risku, tādēl jebkura pazīme, kas spētu norādīt par agrīnu slimības aktivitāti, ir ar potenciālu šo risku samazināt. Būtiski atcerēties, ka neizskaidrojama nieze atsevišķos gadījumos var būt kā pirmais brīdinājuma signāls par NMO paasinājuma sākumu.

\subsubsection{Toniskas spazmas}

TS dažreiz aprakstītas arī kā paroksizmāla distonija, ir pēkšņas, nekontrolētas, paroksizmālas, īsas un stereotipas kustības, kuru rezultātā locekḷos rodas distoniskas, visbiežāk vienpusējas, pozas izmaiņas, bet bez paliekošiem funkcionāliem traucējumiem. Pacientam TS var būt ḷoti mokoši un sāpīgi, bet nereti viegli koriǵējami ar membrānu stabilizējošiem mediķamentiem, tādiem kā karbamazepīnu. Lai uzlabotu dz̄ives kvalitāti šiem slimniekiem, ir l̦oti svarīgi šo klīnisko sindromu atpazīt savlaicīgi. TS rodas, ja ir bojāti kustību cel̦i (jebkurā CNS līmenī), bet visbiežāk - muguras smadzeņu bojājuma rezultātā. Tiek uzskatīts, ka TS, līdzīgi kā citi DS raksturīgi paroksizmāli stāvokḷi, rodas pastiprinātas ektopisku impulsu darbības dēl 
pārmērīgas aksonu uzbudināmības rezultātā (Matthews 1958) (Ostermann and Westerberg 1975).

TS var veicināt apzināta kustība, emocijas vai hiperventilācija. CNS bojājuma rezultātā TS nereti pavada sensori vai motori traucējumi locekḷos vai ķermen̄i. TS var izpausties dažādu DS gadījumos arī kā to pirmā klīniskā pazīme (Matthews 1958, Zhao, Mutch et al. 2014, Muto, Mori et al. 2015). TS sastopamība MS slimniekiem ir aptuveni 4-17\% (Matthews 1958, Kuroiwa and Araki 1963, Shibasaki and Kuroiwa 1974, Matthews 1975). NMO / NMOS pacientiem TS novēro daudz biežāk (14-95\%) (Wingerchuk, Hogancamp et al. 1999, Kim, Go et al. 2012, Usmani, Bedi et al. 2012, Abaroa, RodriguezQuiroga et al. 2013).

Šì pētījuma rezultāti apstiprina, ka TS ir l̦oti biežs (> 55\%) invalidizējošs atlieku simptoms pēc pārciesta mielīta slimniekiem ar NMO / NMOS. Ir uzskatāmi, ka TS novēroja biežāk pētījumos ar prospektīvu (pacientu intervijas) ne retrospektīvu (medicīniskās dokumentācijas analīze) dizainu (Wingerchuk, Hogancamp et al. 1999, Kim, Go et al. 2012, Usmani, Bedi et al. 2012, Abaroa, Rodriguez-Quiroga et al. 2013). TS ievērojami biežāk (38\% salīdzinot ar 5\%) novēro AQP4-IgG pozitīviem slimniekiem (Iorio, Damato et al. 2013). Šī un iepriekšējo pētījumu dati liek domāt, ka TS nav raksturojoša klīniskā pazīme NMO/NMOS slimniekiem.

Retos gadījumos (šajā pētījumā - 4,5\%) TS var izpausties kā mielīta pirmais simptoms, tomēr vairumam slimnieku - atveseļošanās fāzē pēc pirmā TM. Tas, savukārt, vedina domāt par dal̦ējas remielinizācijas lomu TS attīstībā (Kim, Go et al. 2012). Tādēḷ, ja vien spazmi nav mielìta pirmā klīniskā izpausme, ārstēšana ar kortikosteroīdiem visticamāk būs neefektīva. Līdzị̂i kā citu autoru ziņojumos, arī šajā pētījumā iesaistītie pacienti TS terapijā saņēma karbamazepīnu, gabapentīnu, fenitō̄nu. Vispārliecinošāko efektivitāti uzrādīja karbamazepīns, kas liek domāt par pārejošu jonu kanālu disfunkciju kā primāro patoǵenētisko mehānismu TS pacientiem ar aktīvu demielinizāciju (Waubant, Alize et al. 2001).

Šì pētījuma rezultātu interpretāciju ietekmē vairāki faktori. Viens no tiem - retrospektīvs pētījuma dizains. Nesenā literatūrā TS biežums MS slimniekiem nav atspoguḷots, un, lai precīzi izvērtētu atšķirības starp abām slimībām, nepieciešams veikt salīdzinošu prospektīvu pētījumu. Citi ierobežojošie faktori: pacientu atlase rada selekcijas novirzi, nejaušas sakritības iespēja, nav pielīdzinātas salīdzinošās kontroles grupas, kā kontroles grupa izmantota vēsturiskā grupa jeb literatūras dati, kas, iespējams, ir atšķirīga. 


\subsubsection{MOG-IgG pozitīvu gadījumu fenotips}

Ir zināms, ka NMO slimniekiem, kuru serumā (līdz 90\%) konstatē AQP4 - IgG antivielas, ir paaugstināts turpmāku paasinājumu risks (Matiello, Lennon et al. 2008, Weinstock-Guttman, Miller et al. 2008, Akman-Demir, Tuzun et al. 2011, Etemadifar, Mollabashi et al. 2012), un lai tos pasargātu no turpmākiem recidīviem un invaliditātes, nepieciešams savlaicīgi uzsākt ilgstošu imūnsupresīvu terapiju. Seronegatīvi NMO gadījumi (10-30\%) gan klīnicistiem, gan pētniekiem nereti ir kā mistērija.

Relatīvi nesen daļai AQP4-IgG negatīvu ON, TM un NMO slimnieku serumā izdevās noteikt anti-MOG antivielas (MOG-IgG), kas saistās ar specifisku mielīna oligodendrocītu olbaltumvielu. Analīžu sensitivitāte un specifitāte atkarīga no pielietotās metodologijijas. Vienā no pētījumiem vairumam (3/4) MOG-IgG pozitīvu (AQP4-IgG negatīvu) NMO slimnieku novēroja monofāzisku slimības norisi, kas raksturojās ar mazāk izteiktu neiroloǵisko funkciju zudumu. Tā rezultātā pētnieki secināja, ka MOG-IgG antivielas reprezentē ADEM tipa saslimšanu un relatīvi labvēlīgu iznākumu (Kitley, Woodhall et al. 2012, Kitley, Waters et al. 2014). Kādā citā laboratoriskā pētījumā ar pelēm novēroja MOG-IgG mediētu demielinizāciju (ar sekojošu remielinizāciju), bet bez AQP4-IgG pozitīvam NMO raksturīgā astrocītu bojājuma, komplementa aktivācijas vai izteiktas iekaisuma reakcijas, un klīniski izpaužoties bez izteikta funkciju deficīta (Saadoun, Waters et al. 2014), tādējādi apstiprinot iepriekšējās pētnieku grupas izvirzīto hipotēzi. Tomēr, neskatoties uz iepriekšējiem ziņojumiem, arvien biežāk tiek ziņots par MOG-IgG seropozitivitāti slimniekiem ar recidivējošu norisi (Rostasy, Mader et al. 2012, Ramanathan, Reddel et al. 2014, Tsuburaya, Miki et al. 2015). Interesants ir fakts, ka kādā nesenā pētījumā recidivējošo MOG-IgG pozitīvu ON slimnieku mediānais gada paasinājumu skaits $(0,5)$ būtiski neatšks̄īās no AQP4-IgG pozitīviem $(0,7)$ vai AQP4-IgG negatīviem $(0,9)$ NMO pacientiem (Sato, Callegaro et al. 2014). Līizīgi arī šajā pêtījumā - nozīmīgs paasinājumu skaits bija fiksēts 4/11 pacientiem, kuru novērošanas ilgums bija vairāk nekā 3 gadi. Četriem pacientiem, kam registrēts tikai 1 paasinājums, slimības ilgums bija mazāk nekā 2 gadi. Jāuzsver, ka šajā pêtījumā apkopoti dati tikai par recidīviem, kas apstiprināti pēc neirologiskas pacientu izvērtēšanas un/vai radioloǵiski. Divos gadījumos (skat. 2.5. tabulā 2., 9. gadījumu) tika novēroti pārejoši traucējumi, kas izpaudās, samazinot sterō̄du devu vai saistībā ar infekciju, tādēl tie netika ieskaitīti kā paasinājumi. 
Šis pētījums raksturo 6 MOG-IgG (MOG-IgG1 subtips) pozit̄̄vus (AQP4-IgG negatīvus) recidivējošus NMO gadījumus, tādējādi apgāžot hipotēzi par MOG-IgG kā biomarķieri ADEM tipa jeb monofāziskam NMO un mazāk izteiktam neiroloǵisko funkciju defícītam. Kopumā šajā darbā aprakstīti 11 MOG-IgG1 pozitīvi NMO vai aizdomu NMOS gadījumi (8 AQP4-IgG negatīvi NMO un 3 pacienti ar klīniski limitētu formu). Pētījuma rezultātā jāsecina, ka MOG-IgG antivielas nav unikāls biomarķieris monofāziskai slimības norisei vai klīniski neizteiktam funkciju zudumam, un ir sastopamas arī recidivējošos NMO gadījumos ar izteiktu invaliditāti. Šì pētîjuma pēdējā novērošanas vizītē izteikti redzes vai motorie traucējumi tika reǵistrēti vairāk nekā pusei slimnieku. Turklāt, neskatoties uz to, ka funkciju atjaunošanās pēc PKE bija relatīvi laba.

Redzes nerva neirīts un mielīts vienlaicīgi, sekojot prodroma periodam, novērots gan monofāziska, gan recidivējoša NMO gadījumos. Interesants ir fakts, ka vidējais saslimšanas vecums bija lielāks slimniekiem ar monofāzisku norisi $(29,5 \pm 12$ salīdzinot ar $20 \pm 9)$.

Pēc literatūras datiem vairumam NMO slimnieku, atšķirībā no MS, oligoklonālās ķēdes ir negatīvas, bet citoze nereti ir augstāka par 50. Arī šajā pētījumā rezultāti bija līdzīgi: oligoklonālās ķēdes bija negatīvas $8 / 8$ gadījumos, savukārt pleocitoze $>100$ konstatēta $71 \%$ (5/7) gadījumu.

Lai izvairītos no viltus pozitīviem gadījumiem, pozitīvie paraugi tika testēti atkārtoti, izmantojot pašreiz labāko pieejamo metodiku un nosakot MOG-IgG1.

Ir būtiski ārstēt recidivējošus NMO (t. sk. AQP4-IgG negatīvus) slimniekus jau preventīvi, pielietojot imūnsupresīvus medikamentus (Jacob, McKeon et al. 2013). Neskatoties uz iepriekšêjiem ziņojumiem, š̄i pētījuma rezultātā neradās pārliecība, ka MOG-IgG pozitīvos gadījumos neirologisko funkciju zudums ir viegls vai antivielu klātbūtne norāda uz monofāzisku slimību. Jāatzīmēe, ka MOG-IgG loma joprojām nav pilnībā noskaidrota un vadīties tikai pēc MOG-IgG analīžu rezultātiem, lai izteiktu prognostiskos minējumus un izdarītu ārstēšanas izvēli šiem pacientiem, nebūtu ètiski. Kādā ziņojumā imūnsupresīva terapija - p/o sterō̄di (9) kopā ar/bez azatioprīnu (4) vai mitoksantrons (1) tika uzsākta vairāk nekā pusei (10/16) pacientu, no kuriem 70\% (7/10) pēc tam novēroja klīnisku remisiju (Sato, Callegaro et al. 2014).

Pētījumu ierobežojošie faktori: retrospektīvs dizains, gadījumu sērija nav pilnīga gadījumu uzskaite, pacientu atlase rada selekcijas novirzi, nejaušas 
sakritības iespēja, nav pielīdzinātas salīdzinošās kontroles grupas, kā kontroles grupa izmantota vēsturiskā grupa jeb literatūras dati, kas, iespējams, ir atšķirīga. Dažādos pētījumos, MOG-IgG antivielu noteikšanai, nereti izmantota arī atšķirīga metodika ar nevienlīdzīgu sensitivitāti un specifitāti.

\subsection{Optiskā neiromielīta ārstēšanas raksturojums}

\subsubsection{Recidīvu ārstēšana ar intravenoziem imūnglobulīniem}

NMO / NMOS slimniekiem funkciju deficīts akumulējas ar katru recidīvu, radot neatgriezenisku invaliditāti, tādēl agresīva un savlaicīga paasinājumu ārstēšana ir vitāli svarīga. Lai arī NMO ārstēšanā ir pieejami vairāki medikamenti, tiem galvenokārt ir tikai preventīva ietekme, paasinājumu kupēšanai aprobežojoties ar kortikosteroīdu lietošanu vai to nepiln̄̄gas efektivitātes gadījumā - ar plazmaferēzi (PLEX). Praksē IVIG lieto dažādu imūnsistēmas mediētu akūtu stāvokḷu, piemēram, miastēnijas un Gijēna Barrē sindroma (GBS) gadījumā, kā arī NMO recid̄̄vu preventīvai terapijai (Bakker and Metz 2004, Okada, Tsuji et al. 2007, Magraner, Coret et al. 2013, Wingerchuk 2013). To potenciāls NMO paasinājumu akūtā periodā līdz šim nav apzināts. Šis ir pirmais ziņojums par IVIG pielietojumu NMO paasinājumu ārstēšanā.

Šajā pētījumā nozīmīga neiroloǵisko funkciju uzlabošanās pēc IVIG kursa bija novērojama gandrīz pusei (5/11 jeb 45,5\%) slimnieku. Vairums no tiem (4/5), kas uzrādīja nozīmīgu klīnisku efektivitāti, bija AQP4-IgG pozitīvi. Atlikušajos gadījumos (6/11) bija vērojama stāvokḷa stabilizācija.

Lai gan ir gandrīz neiespējami norobežot IVIG terapijas efektu no iepriekš saņemto steroīdu un PLEX potenciālā vēlīnā efekta (tipiskā gadījumā prednizolonu turpina vairāku mēnešu garumā pēc akūta terapijas kursa), tomēr jāatzīmē, ka nozīmīga neiroloǵisko funkciju atjaunošanās ir vērojama tajos gadījumos, kad IVIG ārstēšana uzsākta agrīnāk: mediānais laiks - $1(0-2)$ nedēlas kopš simptomu sākuma salīdzinājumā ar mediāno laiku - 3,5 (0,5-6) mēneši pārējos gadījumos. Visiem slimniekiem (izṇemot vienā gadījumā), kam nozīmīgs funkciju uzlabojums netika novērots, jau bija izteikti neatgriezeniski reziduāli traucējumi pēc iepriekšêjiem paasinājumiem, tādēḷ nozīmīgs uzlabojums nebija sagaidāms.

Pētījuma rezultātā jāsecina, ka nopietnu blakṇu risks, NMO paasinājumu akūtā periodā pielietojot IVIG, ir relatīvi zems. Vienā no gadījumiem pēc IVIG 
kursa attīstìjās miokarda infarkts un pneimonija, visticamāk multifaktoriālas etiologijas. Jāpiebilst, ka šai pacientei jau bija paaugstināts komplikāciju risks lielā vecuma un izteiktā funkciju deficìta (tetraparēze, sekundāra hipoventilācija) dēl, kā arī IVIG tika uzsākts vienlaicīgi ar azatioprīnu.

Būtiskākais šī pētījuma ierobežojošais faktors ir tā retrospektīvs dizains. Arī neliels slimnieku skaits un izteikta intervālu atšķirība starp saņemto ārstēšanu un funkciju izvērtēšanu (0-12 mēneši), kā arī citu medikamentu pielietošana liek būt piesardzīgiem, izdarot galējos secinājumus par IVIG efektivitāti NMO paasinājumu ārstēšanā. Citi ierobežojošie faktori: gadījumu sērija nav pilnīga gadījumu uzskaite, pacientu atlase rada selekcijas novirzi, nejaušas sakritības iespēja, nav salīdzinošās kontroles grupas. Lai būtu skaidra pārliecība par klīniski nozīmīgu IVIG efektivitāti, pētījuma rezultātus nepieciešams apstiprināt randomizētā pētījumā ar lielāku slimnieku skaitu.

\subsection{2. Ārstēšana ar azatioprīnu}

Randomizēti pētījumi par NMO ārstēšanu līdz šim nav veikti, terapijas izvēle ir empīiska un balstîta uz gadījumu sēriju aprakstiem. Vairums imūnsupresantu, ko izmanto NMO ārstēšanā, vidējo gada recidīvu skaitu samazina no 1,48-2,8 uz 0-0,93, slimības remisiju nodrošinot 37-74\% pacientu (Mandler, Ahmed et al. 1998, Cree, Lamb et al. 2005, Weinstock-Guttman, Ramanathan et al. 2006, Watanabe, Misu et al. 2007, Jacob, Weinshenker et al. 2008, Jacob, Matiello et al. 2009, Bichuetti, Lobato de Oliveira et al. 2010, Bedi, Brown et al. 2011, Costanzi, Matiello et al. 2011, Kim, Kim et al. 2011, Pellkofer, Krumbholz et al. 2011, Cabre, Olindo et al. 2013, Ip, Lau et al. 2013, Kim, Huh et al. 2013, Kitley, Elsone et al. 2013, Pittock, Lennon et al. 2013, Elsone, Kitley et al. 2014, Huh, Kim et al. 2014). Salīdzinājumā ar citiem medikamentiem, azatioprīns (AZA) tā pieejamības, zemo izmaksu un blakņu profila dēḷ ir viens no plašāk lietotiem imūnsupresantiem NMO ārstēšanā. AZA ir tiopurīns, un tā imūnsupresējošais efekts izpaužas kā endogēno purīnu, kas ir DNS, RNS un atsevišķu enzīmu sastāvā, antagonistam (Sahasranaman, Howard et al. 2008). AZA tiek metabolizēts ar tiopurīna metiltransferāzes (TPMT) palīdzību. Pacientiem ar iedzimtu TPMT deficītu vai samazinātu aktivitāti (apmēram 11\% populācijas), ir paaugstināts AZA toksicitātes risks, t.sk. mielotoksicitātes. AZA sākotnējā deva NMO gadījumos parasti ir $25 \mathrm{mg}$ p/o dienā, pakāpeniski paaugstinot līdz 2,5-3mg/kg/dienā. Nereti to uzsāk vienlaicīgi ar prednizolonu $0,5-1 \mathrm{mg} / \mathrm{kg} / \mathrm{dien} \bar{a}$, kas, sasniedzot AZA terapeitisko 
devu, tiek lēnām samazināts līdz minimālai devai (galvenokārt 6 mēnešu laikā) (Palace, Leite et al. 2012, Jacob, McKeon et al. 2013). Neskatoties uz terapeitisko efektivitāti, AZA lietošanu nereti pārtrauc izteiktās nepanesamības vai turpmāko recidīvu dēls. AZA efektivitāte bieži recidivējoša un/vai klīniski smagi noritoša NMO / NMOS ārstēšanā, kā arī tā pārtraukšanas riski un pielietojums ilgtermiņā pacientiem ar NMO/NMOS nav iepriekš pētīiti.

Šis ir līdz šim plašākais pētījums par AQP4-IgG pozitīvu NMO / NMOS ārstēšanu, savukārt pirmais ziṇojums par AZA efektivitāti bieži recidivējoša un smagi noritoša NMO / NMOS gadījumā. Pētījumā, lai izvairītos no iespējamām diagnostikas kḷūdām, iekl̦auti tikai AQP4-IgG pozitīvi gadījumi. Pētījuma slimnieki AZA uzsāka mediāni 2 gadus pēc saslimšanas sākuma un 3 slimības paasinājumiem. Pētījuma rezultāti parādīja, ka $89 \%$ no visiem slimniekiem novēroja paasinājumu skaita samazinājumu (mediānais RSG samazinājums no 1,6 līdz 0,1), kas ir līdzīgi kā iepriekšējos ziņojumos par AZA efektivitāti NMO slimniekiem (Costanzi-76\%, Bichuetti-70\%, Mandler - 100\%).

Nozīmīgs recidīvu skaita samazinājums vērojams arī $86 \%$ ANMO gadījumos (mediānais RSG samazinājums no 3,8 līdz 0,21). Piln̄̄gu klīnisku remisiju novēroja $61 \%$ no visiem pētījumā iekḷautiem pacientiem un $44 \%$ pacientu ar ANMO, neiroloǵisko funkciju uzlabojumu vai stabilizāciju - 78\% no visiem pacientiem. Analizējot tikai pacientus ar novērošanas periodu ilgāku par 6 mēnešiem (izslēdzot tos, kas AZA uzsākuši salīdzinoši nesen vai pārtraukuši agrīni), pacientu skaits, kam novēroja pilnīgu klīnisku remisiju, samazinājās līdz 49\%. Vienlaicīgi rezultāti norāda uz AZA efektivitātes proporcionālu samazinājumu slimniekiem ar pirms ārstēšanas periodā paaugstinātu slimības aktivitāti un garāku novērošanas periodu. Svarīgi ir atzīmēt, ka, neskatoties uz nozīmīgu RSG samazinājumu un to, ka vairumam slimnieku novēroja slimības remisiju, šis pētījums viennozīmīgi demonstrē, ka AZA pacientiem ar ANMO ir salīdzinoši mazāk efektīvs kā pacientiem ar zemāku slimības aktivitāti.

Interesants ir fakts, ka gandrīz trešdaļai (12/40 jeb 30\% kopējā grupā un 7/20 jeb 35\% ANMO) recidivējošo slimnieku jauns paasinājums attīstījās pirmo 3-4 mēnešu laikā, kas, iespējams, saistīts ar lēnu medikamenta titrēšanu, tādējādi paildzinot nepieciešamo laiku piln̄̄gas efektivitātes sasniegšanai. Lai gan, jāpiebilst, ka slimniekiem ar ANMO laiks līdz nākamajam paasinājumam bija īsāks (24 salīdzinot ar 52 mēnešiem). Iespējams to dal̦ēji ietekmēja zemāka medikamenta deva pacientiem ar ANMO. Būtiski ir atzīmēt, ka terapiju pēc pirmā recidīva pārtrauca tikai vienam no slimniekiem ar ANMO un 12 no 19 
gadījumos novēroja atkārtotus klīniskus recidīvus. Mediānais laiks līdz otrajam paasinājumam (176 mēneši attiecībā pret 84 mēnešiem) arī bija garāks pacientiem ar zemāku slimības aktivitāti pirms ārstēšanas etapā.

Jāatzīmē, ka nozīmīgam slimnieku skaitam AZA lietošanas laikā reǵistrēta vismaz viena medikamenta blakne, kuru dēl ārstēšanu pārtrauca 47\% (29/62) slimnieku. AZA blakusefekti izrādījās arī biežākais medikamenta pārtraukšanas iemesls - 62\% (n = 29/47), salīdzinot ar $15 \% \quad(7 / 47)$ paasinājumu, 2\% (1/47) grūtniecības un 2\% (1/47) neprecizētu iemeslu dēḷ. Vēl 9 gadījumos medikaments pārtraukts, iestājoties exitus letalis, kas bija saistīts drīzāk ar slimības terminālu stāvokli kā medikamenta lietošanu (visos gadījumos bija vērojama nozīmīga invaliditāte jau pirms medikamenta uzsākšanas). Interesants ir fakts, ka blakṇu dēl ārstēšanu pārtrauca arī 38\% (24/63) pacientu, kam vēroja klīnisku remisiju. Līdzīgs blakṇu dēḷ pārtraukušo slimnieku skaits (58\%) bija arī citos ziṇojumos par NMO, tomēr procentuāli augstāks kā citu slimību gadījumos (salīdzinoši līdz 22\%) (Pinto, Chebli et al. 2009, Prefontaine, Macdonald et al. 2010, Costanzi, Matiello et al. 2011, Timmer, McDonald et al. 2012, Chaparro, Ordas et al. 2013, Oglesby, Shaul et al. 2013).

Viens no būtiskākiem blakus efektiem, kuru dēḷ tika pārtraukts AZA (trešdaļa gadījumu) bija hematolog̣iski traucējumi (limfopēnija, neitropēnija vai pancitopēnija). Mērķtiecīgu limfopēniju un makrocitozi ar saglabātu neitrofīlo skaitu nereti izmanto kā marķieri medikamenta efektivitātes izvērtēšanai, tādēl medikamenta pastāvīgu pārtraukšanu daudzos gadījumos var novērst ar devas īslaicīgu korekciju. Līdzīgi ir ar aknu enzīmu paaugstinājumu, kas nereti ir tikai pārejošs un izzūd, īslaicīgi samazinot vai pārtraucot medikamenta lietošanu. Medikamenta pārtraukšana vai turpināšana šādos apstākḷlos nereti saistīta ar klīnicista pieredzi medikamenta lietošanā. Tomēr ir neiespējami noteikt un nodalīt, vai blaknes bija saistītas vien̄̄gi ar AZA lietošanu. Visi pētījuma slimnieki blakus terapijā sañēma arī citus medikamentus, piemēram, steroīdus, pretsāpju, urīnpūšla disfunkcijas, spazmu u.c. simptomu korekcijai. No visiem blakus efektiem, kas pētījumā tika atklāti, visticamāk ar AZA lietošanu saistāmi hematolog̣iskie un gastrointestinālie traucējumi. Hematologisku izmaiṇu dēl AZA pārtrauca 8\% (8/103) un gastrointestinālu traucējumu dēl - 18\% (18/103) pētījuma slimnieku. Rezultāti ir līdzīgi kā citā ziņojumā ar nākamo lielāko NMO/NMOS pacientu skaitu, kas bija ārstēti ar AZA: 9\% (6/70) un vismaz 14\% (10/70) (Costanzi, Matiello et al. 2011). Lielākos randomizēti kontrolētos pētījumos, kur AZA sañēma citu saslimšanu terapijā, hematologiiskas blaknes 
bija konstatētas 6-50\%, bet gastrointestinālas - 3-21\% pacientu, savukārt infekcijas ārstēšanas laikā attīstījas $42 \%$ gadījumu (Chaparro, Ordas et al. 2013).

Pētījuma rezultāti apstiprina, ka AZA kopā ar zemas devas prednizolonu ir efektīvs būtiskam NMO/NMOS slimnieku skaitam. To pašu gan nevar teikt par slimniekiem ar ANMO, kad jau ārstēšanas sākumā būtu svarīgi izvēlēties efektīvāko medikamentu.

Jāatzīmē, ka arī šī pētījuma rezultātu interpretēšanu ietekmē vairāki faktori. Viens no tiem ir pētījuma retrospektīvs dizains. Pastāv arī iespējamība, ka mazāk izteiktas blaknes nebija dokumentētas. Vienlaicīgi, nebija zināms katra individuālā pacienta k̦ermeņa svars ārstēšanas periodā, tādēl AZA devu atbilstoši ķermen̦a masai nebija iespējams aprēķināt. Pētījumā nebija zināmas arī precīzas medikamentu devas un MCV (vidējais eritrocītu tilpums) recidīvu laikā, ko nereti izmanto kā biomarķieri AZA efektivitātes izvērtēšanā (Costanzi, Matiello et al. 2011). Nebija zināms arī augstas devas kortikosterō̄du lietošanas ilgums pacientiem, kam attīstījās jauni paasinājumi. Citi ierobežojošie faktori: gadījumu sērija nav pilnīga gadījumu uzskaite, pacientu atlase rada selekcijas novirzi, nejaušas sakritības iespēja, nav pielīdzinātas salīdzinošās kontroles grupas, kā kontroles grupa izmantota vēsturiskā grupa jeb literatūras dati, kas, iespējams, ir atšķirīga.

\subsection{Latvijas MS reǵistrā ievadāmo datu analīze}

Ir zināms, ka NMO gadījumi nereti tiek sākotnēji kḷūdaini diagnosticēti kā MS. Līdz 2009. gada decembrim Latvijas MS reǵistrā bija iekḷauti vairāk nekā 1600 gadījumi ar apstiprinātu MS diagnozi (A grupa) un vismaz vēl tikpat ar aizdomu MS diagnozi vai citu neprecizētu DS (B grupa). Ja pieņem, ka katrs 40-100 MS slimnieks ir neatpazīts NMO, tad Latvijā kopumā būtu jābūt reǵistrētiem vismaz 40-160 NMO slimniekiem (Wingerchuk, Lennon et al. 2006, Asgari, Lillevang et al. 2011). Vadoties pēc literatūras datiem par NMO prevalenci $(0,32-4,40$ uz 100 000), minimālais Latvijā sagaidāmais NMO gadījumu skaits (pēc statistikas pārvaldes datiem kopējais reǵistrētais iedzīvotāju skaits 2014. gada sākumā bija 2001500) ir 6 līdz 88. Interesants ir fakts, ka, lai gan līdz pat 2012. gadam slimniekus uz MS centru LJMC nosūtīja no visas Latvijas, laika periodā no 2003. gada septembra līdz 2009. gada decembrim ieskaitot NMO diagnoze netika apstiprināta nevienam slimniekam, bet 2 tika izteiktas aizdomas par NMO. Iespējams, tas izskaidrojams ar 
nepietiekamu slimības atpazīstamību, kā arī to, ka Latvijā uz vietas specifisku antivielu (AQP4-IgG jeb NMO-IgG) noteikšana šajā periodā nebija pieejama, bet analīžu veikšana ārpus valsts robežām bija izpildāma vienīgi kā maksas pakalpojums.

Latvijas MS pacienta apsekošanas karte (turpmāk - MS karte) aptver lielu daļu biežāk starptautiskā praksē lietotos moduḷus un datus, kas nepieciešami MS prevalences un incidences aprēķiniem. Iespējams pievienot arī datus par B (aizdomu MS) un C (apstiprināta cita saslimšana, kas izskaidro simptomus) grupu pacientiem t. sk. klīniski izolētu sindromu, aizdomu MS, NMO u. c. demielinizējošām saslimšanām, līdzīgi kā tas ir, piemēram, Dānijas, Zviedrijas, Itālijas, Lionas (EDMUS) u. c. MS reǵistros vai datu bāzēs. Tomēr Latvijas MS reǵistrā mērķtiecīgi dati tiek ievadīti tikai par pacientiem ar apstiprinātu MS diagnozi. Vairākās valstīs, tādās kā Dānija, Francija, Koreja, Indija u. c., kur MS vai aizdomu MS slimnieku datus ievada DS/MS reǵistrā, pēc dažādām klīniskām un radiologiskām pazīmēm izdevies retrospektīvi atlasīt pacientus ar iespējamu NMO diagnozi un nosūtīt laboratoriskai izmeklēšanai un diagnozes precizēšanai (Cossburn, Tackley et al. 2012, Pandit, Mustafa et al. 2013, Viswanathan, Arip et al. 2014).

Pie NMO slimnieku būtiskākajām raksturojošajām pazīmēm jāatzīmē: redzes nerva neirīts ar vienpusēju vai abpusēju izteiktu redzes zudumu un longitudināls mielīts ar izteiktiem kustību, jušanas un mazā iegurņa orgānu darbības traucējumiem (vairāk nekā 3 vertebrālo segmentu garumā) un nepilnīgu funkciju atjaunošanos, neskatoties uz saṇemto ārstēšanu. Tos nereti pavada vemšana, slikta dūša, ilgstoša žagošanās, nieze, sāpes vai toniskas spazmas. NMO raksturīga arī normāla atradne vai nespecifiski perēkḷi sākotnējā galvas smadzeņu MR izmeklējumā, negatīvas oligoklonālās ķēeses, stāvokḷa pasliktināšanās, saņemot MS ārstēšanai paredzētos medikamentus, piemēram, beta interferonus, natalizumabu, fingolimodu u. c. Savukārt MS raksturojas ar vieglu vai mēreni izteiktu vienpusēju redzes nerva neirītu, mielītu (muguras smadzeņu perēkḷi MR tipiski nepārsniedz viena segmenta garumu), ar labu funkciju atjaunošanos neatkarīgi no tā, vai saņemta ārstēšana, pozitīvām oligoklonālām ķēēem likvorā.

MS kartē anamnēzes sadaļa ir detalizēta, tai pašā laikā uzskaitot tikai daļu, pēc nezināmiem kritērijiem atlasītus, MS simptomus (ne būtiskākos, arī nenorādot to smaguma pakāpi). Arī informācija par veiktiem izmeklējumiem un saņemto ārstēšanu ir ļoti virspusīga, vai daudzi nozīmīgi rādītāji vispār netiek iekḷauti. Tas, savukārt var novest pie neatgriezeniskām sekām 
(dubultārstēšana, blaknes utt.), kā arī automātiski izslēdz iespēju pārskatīt un kontrolēt registrēto MS gadījumu atbilstību slimības diagnostiskiem kritērijiem, kā arī iespēju retrospektīvi atklāt citu saslimšanu, t. sk. NMO. Arī datu automātiska vai manuāla pārskatǐšana par atbilstību prasībām, starptautiskiem kritērijiem, definīcijām utt. pēc to apkopošanas anketā vai ievades reǵistrā netiek veikta, tādējādi ievadāmo datu kḷūdas varbūtība ir paaugstināta. Novērojamas arī daudzas citas būtiskas neprecizitātes attiecībā uz MS kartē un tātad reǵistrā iekḷaujamo informāciju, kas plašāk aprakstītas promocijas darba pilnajā versijā.

Lai spētu atklāt un atlasīt NMO u. c. DS gadījumus (nereti tiek sākotnēji kḷūdaini diagnosticēti kā MS), reǵistrā būtu nepieciešamas būtiskas izmaiņas. Tajā skaitā, būtiski minēt gadus ne tikai pirmajam un otrajam recidīvam, kā tas ir pašreizējā MS kartē, bet arī turpmākajiem, lai spētu aprēķināt recidīvu biežumu, aprūpes efektivitāti utt., izvēlēties turpmāko ārstēšanas metodi. Arī ambulatorās funkcijas zuduma pakāpes (pārvietojas ar vienpusēju vai abpusēju atbalstu, sēdkrēslā, gulošs u. tml.) konstatēšanas laiks, kā arī EDSS pakāpe dinamikā šobrīd netiek norādīta.

Lai registra datus izmantotu zinātniskiem pētījumiem, pastāv vairāki ierobežojumi, tajā skaitā tehniski un ētiskas dabas, kas sīkāk aprakstīti promocijas darba pilnajā versijā. Šim pētījumam ir savi ierobežojošie faktori: pētījuma analīzei nebija pieejams pats reǵistrs, bet tikai MS pacienta karte, pēc kuras dati ievadāmi, tādēl iespējams, ka MS kartē minētie dati ir ar mazāku apjomu un precīzi neatbilst reǵistrā potenciāli ievadāmo datu apjomam. Vienlaicīgi, literatūras dati par citu valstu DS/MS reǵistriem ir ierobežoti, kas ietekmē datu salīdzināšanas iespējas. Citu medicīnisko resursu, tādu kā stacionāro vai ambulatoro karšu ierakstu izvērtējums šajā pētījumā netika veikts. 


\section{SECINĀJUMI}

1. Salīdzinoši gada mēnešus, NMO / NMOS paasinājumu aktivitāte, pretēji MS, bija nedaudz zemāka jūnija, bet paaugstināta - oktobra un novembra mēnešos, taču, lai pārliecinoši izteiktos par NMO / NMOS sezonālu raksturu, ir nepieciešami plašāki, prospektīvi pētījumi.

2. Nozīmīgai pacientu daļai (18\%) novēro progresējošu saslimšanas sākumu, respektīvi - simptomu kulmināciju pirmā paasinājuma laikā sasniedzot pakāpeniski 4 un vairāk nedēḷu laikā. Šāds saslimšanas sākums AQP4-IgG negatīviem pacientiem ir novērojams biežāk nekā AQP4-IgG pozitīviem pacientiem. Savukārt, sekundāri progresīva norise NMO / NMOS nav raksturīga (novēro tikai līdz $4 \%$ gadījumu).

3. Neiropātiskā nieze ir bieža un raksturojoša NMO klīniskā pazīme, kuru novēro vismaz trešdal̦ai NMO / NMOS slimnieku ar transversālu mielītu, bet ceturtdaļai slimnieku tā var izpausties kā pirmais paasinājuma simptoms. Toniskas spazmas ir biežs (līdz pat 55\%) un raksturojošs NMO / NMOS simptoms pacientiem ar transversālu mielītu, un to galvenokārt novēro atveseļošanās fāzē. Tikai nelielai daļai (4,5\%) TS izpaužas kā mielīta pirmā izpausme.

4. Pretēji iepriekš uzskatītajam, NMO / NMOS pacientiem ar pozitīvām MOG-IgG antivielām, var novērot ne tikai monofāzisku, bet arī recidivējošu norisi, savukārt, neiroloǵisko funkciju deficīts var būt ar dažādu izteiktības pakāpi.

5. Imūnglobulīni, ievadīti intravenozi, ir efektīvi agrīnā NMO / NMOS paasinājumu terapijā gandrīz pusei slimnieku.

6. Azatioprīns ir efektīvs medikaments NMO / NMOS recidīvu preventīvai ārstēšanai, samazinot vidējo gada paasinājumu skaitu līdz pat $89 \%$ slimnieku un nodrošinot piln̄̄gu klīnisku remisiju līdz pat $61 \%$, tomēr tā efektivitāte slimniekiem ar izteiktāku slimības aktivitāti (biežiem recidīviem) ir ievērojami zemāka.

7. Latvijas MS reǵistrā iekḷaujamo datu kvalitāte un kvantitāte nav pietiekama, lai retrospektīvi atklātu NMO / NMOS gadījumus. 


\section{REKOMENDĀCIJAS}

\subsection{Klīniski praktiskās rekomendācijas NMO/NMOS slimnieku diagnostikas un ārstēšanas uzlabošanai}

1. Visos gadījumos ar raksturīgu klīnisko sindromu (ON, TM), pat ja slimība norit progresējoši (saslimšanas sākumā vai vēlāk), nepieciešams apsvērt NMO/NMOS varbūtību un nosūtīt atbilstošai izmeklēšanai.

2. Neizskaidrojama nieze atsevišķos gadījumos var būt kā pirmais brīdinājuma signāls par NMO paasinājuma sākumu. Ja slimniekam ar demielinizējošai saslimšanai raksturīgu sindromu anamnēzē attīstās neizskaidrojama nieze, lokalizēta dermatomu robežām raksturīgā apvidū, svarīgi pievērst uzmanību, vai neattīstīsies citi neirologiski simptomi, un pie atbilstoša nosacījuma uzsākt savlaicīgu ārstēšanu ar kortikosterō̄diem.

3. TS koriğēěanu ieteicams uzsākt savlaicīgi. TS kupēšanā kā pirmās līnijas medikamentu ieteicams izmantot karbamazepīnu (membrānu stabilizējošs medikaments) un tikai tā neefektivitātes vai nepanesamības gadījumā pāriet uz citu izvēli.

4. MOG-IgG pozitīvos gadījumos rekomendējams vadīties pēc vispārējiem NMO/NMOS terapijas principiem, respektīvi, recidivējošos gadījumos uzsākt agrīnu imunoterapiju.

5. Kortikosteroīdu un plazmaferēzes neefektivitātes gadījumā NMO / NMOS paasinājuma ārstēšanai vēlams nozīmēt papildus IVIG terapijas kursu.

6. Slimniekiem ar ANMO, kā arī turpmāku recidīvu gadījumā, ārstēšanu ieteicams nomainīt ar citu, efektīvāku medikamentu.

7. N̦emot vērā, ka proporcionāli nozīmīgam pacientu skaitam pirmais paasinājums, uzsākot AZA terapiju, attīstījās pirmo 3-4 mēnešu laikā, AZA devas titrēšanu iespēju robežās ieteicams paātrināt jeb turpināt lietot fonā augstas devas kortikosteroīdus līdz pat brīdim, kad AZA titrēšana ir pabeigta.

\subsection{Rekomendācijas Latvijas MS reğistra kvalitātes uzlabošanai}

N̦emot vērā DS un to aprūpes specifiskumu, tajā skaitā nereti augstās ārstēšanas izmaksas, Latvijas DS / MS reǵistrā ievadītai informācijai būtu jāspēj kalpot arī par informācijas avotu nepārtrauktas un pilnvērtīgas šo slimnieku aprūpes nodrošināšanai, t. sk. ārstēšanas efektivitātes, slimības norises un invaliditātes monitorēšanai, dažādu MS subtipu un citu centrālās 
nervu sistēmas DS (t. sk. NMO) gadījumu atklāšanai. Būtiski pārstrādāt esošajās MS kartēs ievadāmo informāciju, vadoties pēc klīniskā, zinātniskā un finanšu resursu plānošanas lietderīguma. Lai to nodrošinātu, nepieciešams vienkāršot lielākajā daļā moduļu iekļautos datus. Tiem jābūt viegli saprotamiem, ērti lietojamiem, kā arī ar turpmāku vērtību.

No ētiskā viedokḷa, būtu rekomendējams izstrādāt un ieviest praksē arī pacientu informētās piekrišanas par to datu ievietošanu MS reǵistrā un potenciālu izmantošanu pētījumos. 


\section{IZMANTOTĀ LITERATŪRA}

1. Abaroa L., Rodriguez-Quiroga S. A., Melamud L., et al. (2013). Tonic spasms are a common clinical manifestation in patients with neuromyelitis optica. Arq Neuropsiquiatr 71(5): 280-283.

2. Abella-Corral J., Prieto J. M., Dapena-Bolano D., et al. (2005). Seasonal variations in the outbreaks in patients with multiple sclerosis. Rev Neurol 40(7): 394-396.

3. Akman-Demir G., Tuzun E., Waters P. S., et al. (2011). Prognostic implications of aquaporin-4 antibody status in neuromyelitis optica patients. J Neurol 258(3): 464-470.

4. Alai N. N., Skinner H. B., Nabili S. T., et al (2010). Notalgia paresthetica associated with cervical spinal stenosis and cervicothoracic disk disease at $\mathrm{C} 4$ through C7. Cutis 85(2): 77-81.

5. Asgari N., Lillevang S. T., Skejoe H. P., et al. (2011). A population-based study of neuromyelitis optica in Caucasians. Neurology 76(18): 1589-1595.

6. Baba T., Nakashima I., Kanbayashi T., et al. (2009). Narcolepsy as an initial manifestation of neuromyelitis optica with anti-aquaporin-4 antibody. J Neurol 256(2): 287-288.

7. Bakker J., L. Metz (2004). Devic's neuromyelitis optica treated with intravenous gamma globulin (IVIG). Can J Neurol Sci 31(2): 265-267.

8. Balashov K. E., Pal G., Rosenberg M. L. (2010). Optic neuritis incidence is increased in spring months in patients with asymptomatic demyelinating lesions. Mult Scler 16(2): 252-254.

9. Bamford C. R., Sibley W. A., Thies C. (1983). Seasonal variation of multiple sclerosis exacerbations in Arizona. Neurology 33(6): 697-701.

10. Bedi G. S., Brown A. D., Delgado S. R., et al. (2011). Impact of rituximab on relapse rate and disability in neuromyelitis optica. Mult Scler 17(10): 1225-1230.

11. Bergamaschi R., Berzuini C., Romani A., Cosi V. (2001). Predicting secondary progression in relapsing-remitting multiple sclerosis: a Bayesian analysis. J Neurol Sci 189(1-2): 13-21.

12. Bichuetti D. B., Lobato de Oliveira E. M., Oliveira D. M., et al. (2010). Neuromyelitis optica treatment: analysis of 36 patients. Arch Neurol 67(9): 1131-1136.

13. Bichuetti D. B., Oliveira E. M., Souza N. A., et al. (2009). Neuromyelitis optica in Brazil: a study on clinical and prognostic factors. Mult Scler 15(5): 613-619.

14. Bichuetti D. B., Rivero R. L., Oliveira D. M., et al. (2008). Neuromyelitis optica: brain abnormalities in a Brazilian cohort. Arq Neuropsiquiatr 66(1): 1-4.

15. Binder A., Koroschetz J., Baron R. (2008). Disease mechanisms in neuropathic itch. Nat Clin Pract Neurol 4(6): 329-337. 
16. Bizzoco E., Lolli F., Repice A. M., Hakiki B., Falcini M., et al. (2009). Prevalence of neuromyelitis optica spectrum disorder and phenotype distribution. J Neurol 256(11): 1891-1898.

17. Cabre P., Olindo S., Marignier R., et al. Aegis of French National Observatory of Multiple (2013). Efficacy of mitoxantrone in neuromyelitis optica spectrum: clinical and neuroradiological study. J Neurol Neurosurg Psychiatry 84(5): 511-516.

18. Cabrera-Gomez J. A., Bonnan M., Gonzalez-Quevedo A., et al. (2009). Neuromyelitis optica positive antibodies confer a worse course in relapsingneuromyelitis optica in Cuba and French West Indies. Mult Scler 15(7): 828-833.

19. Chaparro M., Ordas I., Cabre E., et al. (2013). Safety of thiopurine therapy in inflammatory bowel disease: long-term follow-up study of 3931 patients. Inflamm Bowel Dis 19(7): 1404-1410.

20. Collongues N., Marignier R., Jacob A., et al. (2013). Characterization of neuromyelitis optica and neuromyelitis optica spectrum disorder patients with a late onset. Mult Scler 20(8): 1086-1094.

21. Collongues N., Marignier R., Zephir H., et al. (2010). Neuromyelitis optica in France: a multicenter study of 125 patients. Neurology 74(9): 736-742.

22. Confavreux C., Vukusic S., Adeleine P. (2003). Early clinical predictors and progression of irreversible disability in multiple sclerosis: an amnesic process. Brain 126(Pt 4): 770-782.

23. Confavreux C., Vukusic S., Moreau T., Adeleine P. (2000). Relapses and progression of disability in multiple sclerosis. N Engl J Med 343(20): 1430-1438.

24. Cossburn M., Tackley G., Baker K., et al. (2012). The prevalence of neuromyelitis optica in South East Wales. Eur J Neurol 19(4): 655-659.

25. Costanzi C., Matiello M., Lucchinetti C. F., et al. (2011). Azathioprine: tolerability, efficacy, and predictors of benefit in neuromyelitis optica. Neurology 77(7): 659-666.

26. Cree B. A., Lamb S., Morgan K., et al. (2005). An open label study of the effects of rituximab in neuromyelitis optica. Neurology 64(7): 1270-1272.

27. Damasceno A., Von Glehn F., de Deus-Silva L., Damasceno B. P. (2012). Monthly variation of multiple sclerosis activity in the southern hemisphere: analysis from 996 relapses in Brazil. Eur J Neurol 19(4): 660-662.

28. El Otmani H., Dany F., El Moutawakil B., et al. (2015). Intractable hiccup and vomiting, neuropathic pruritus and tonic spasms in a case of neuromyelitis optica spectrum disorder. Acta Neurol Belg.

29. Elsone L., Kitley J., Luppe S., et al. (2014). Long-term efficacy, tolerability and retention rate of azathioprine in 103 aquaporin-4 antibody-positive neuromyelitis optica spectrum disorder patients: a multicentre retrospective observational study from the UK. Mult Scler 20(11): 1533-1540. 
30. Etemadifar M., Mollabashi M., Chitsaz A., et al. (2012). Seroprevalence of NMOIgG among patients with neuromyelitis optica and opticospinal multiple sclerosis. Clin Neurol Neurosurg 114(1): 17-20.

31. Fonseca A. C., Costa J., Cordeiro C., R. et al. (2009). Influence of climatic factors in the incidence of multiple sclerosis relapses in a Portuguese population. Eur J Neurol 16(4): 537-539.

32. Gratton S., Amjad F., Ghavami F., et al. (2014). Bilateral hearing loss as a manifestation of neuromyelitis optica. Neurology 82(23): 2145-2146.

33. Handel A. E., Disanto G., Jarvis L., et al. (2011). Seasonality of admissions with multiple sclerosis in Scotland. Eur J Neurol 18(8): 1109-1111.

34. Handel A. E., Giovannoni G., Ebers G. C., Ramagopalan S. V. (2010). Environmental factors and their timing in adult-onset multiple sclerosis. Nat Rev Neurol 6(3): 156-166.

35. Handel A. E., Handunnetthi L., Giovannoni G. G., et al. (2010). Genetic and environmental factors and the distribution of multiple sclerosis in Europe. Eur $\mathbf{J}$ Neurol 17(9): 1210-1214.

36. Hart P. H., Gorman S. (2013). Exposure to UV Wavelengths in Sunlight Suppresses Immunity. To What Extent is UV-induced Vitamin D3 the Mediator Responsible? Clin Biochem Rev 34(1): 3-13.

37. Huh S. Y., Kim S. H., Hyun J. W., et al. (2014). Mycophenolate mofetil in the treatment of neuromyelitis optica spectrum disorder. JAMA Neurol 71(11): 1372-1378.

38. Iorio R., Damato V., Mirabella M., et al. (2013). Distinctive clinical and neuroimaging characteristics of longitudinally extensive transverse myelitis associated with aquaporin-4 autoantibodies. J Neurol 260(9): 2396-2402.

39. Ip V. H., Lau A. Y., Au L. W., et al. (2013). Rituximab reduces attacks in Chinese patients with neuromyelitis optica spectrum disorders. J Neurol Sci 324(1-2): 38-39.

40. Iyer A., Elsone L., Appleton R., Jacob A. (2014). A review of the current literature and a guide to the early diagnosis of autoimmune disorders associated with neuromyelitis optica. Autoimmunity 47(3): 154-161.

41. Iuliano G. (2012). Multiple sclerosis: long time modifications of seasonal differences in the frequency of clinical attacks. Neurol Sci 33(5): 999-1003.

42. Jacob A., Hutchinson M., Elsone L., et al. (2012). Does natalizumab therapy worsen neuromyelitis optica? Neurology 79(10): 1065-1066.

43. Jacob A., Matiello M., Weinshenker B. G., Wingerchuk D. M., et al. (2009). Treatment of neuromyelitis optica with mycophenolate mofetil: retrospective analysis of 24 patients. Arch Neurol 66(9): 1128-1133.

44. Jacob A., McKeon A., Nakashima I., et al. (2013). Current concept of neuromyelitis optica (NMO) and NMO spectrum disorders. J Neurol Neurosurg Psychiatry 84(8): 922-930. 
45. Jacob A., Weinshenker B. G., Violich I., et al. (2008). Treatment of neuromyelitis optica with rituximab: retrospective analysis of 25 patients. Arch Neurol 65(11): 1443-1448.

46. Jarius S., Ruprecht K., Wildemann B., et al. (2012). Contrasting disease patterns in seropositive and seronegative neuromyelitis optica: A multicentre study of 175 patients. J Neuroinflammation 9: 14.

47. Jarius S., Lauda F., Wildemann B., Tumani H. (2013). Steroid-responsive hearing impairment in NMO-IgG/aquaporin-4-antibody-positive neuromyelitis optica. J Neurol 260(2): 663-664.

48. Jeffry J., Kim S., Chen Z. F. (2011). Itch signaling in the nervous system. Physiology (Bethesda) 26(4): 286-292.

49. Jin Y., de Pedro-Cuesta J., Soderstrom M., et al. (2000). Seasonal patterns in optic neuritis and multiple sclerosis: a meta-analysis. J Neurol Sci 181(1-2): 56-64.

50. Kanbayashi T., Shimohata T., Nakashima I., et al. (2009). Symptomatic narcolepsy in patients with neuromyelitis optica and multiple sclerosis: new neurochemical and immunological implications. Arch Neurol 66(12): 1563-1566.

51. Kass N. E., Natowicz M. R., Hull S. C., et al. (2003). The use of medical records in research: what do patients want? J Law Med Ethics 31(3): 429-433.

52. Kim S. H., Huh S. Y., Lee S. J., et al. (2013). A 5-year follow-up of rituximab treatment in patients with neuromyelitis optica spectrum disorder. JAMA Neurol 70(9): 1110-1117.

53. Kim S. H., Kim W., Park M. S., et al. (2011). Efficacy and safety of mitoxantrone in patients with highly relapsing neuromyelitis optica. Arch Neurol 68(4): 473-479.

54. Kim S. M., Go M. J., Sung J. J., et al. (2012). Painful tonic spasm in neuromyelitis optica: incidence, diagnostic utility, and clinical characteristics. Arch Neurol 69(8): 1026-1031.

55. Kister I., Chamot E., Salter A. R., et al. (2013). Disability in multiple sclerosis: a reference for patients and clinicians. Neurology 80(11): 1018-1024.

56. Kitley J., Elsone L., George J., et al. (2013). Methotrexate is an alternative to azathioprine in neuromyelitis optica spectrum disorders with aquaporin-4 antibodies. J Neurol Neurosurg Psychiatry 84(8): 918-921.

57. Kitley J., Leite M. I., Nakashima I., et al. (2012). Prognostic factors and disease course in aquaporin-4 antibody-positive patients with neuromyelitis optica spectrum disorder from the United Kingdom and Japan. Brain 135(Pt 6): 1834-1849.

58. Kitley J., Waters P., Woodhall M., et al. (2014). Neuromyelitis optica spectrum disorders with aquaporin-4 and myelin-oligodendrocyte glycoprotein antibodies: a comparative study. JAMA Neurol 71(3): 276-283. 
59. Kitley J., Woodhall M., Waters P., et al. (2012). Myelin-oligodendrocyte glycoprotein antibodies in adults with a neuromyelitis optica phenotype. Neurology 79(12): 1273-1277.

60. Koeppel M. C., Bramont C., Ceccaldi M., et al. (1993). Paroxysmal pruritus and multiple sclerosis. Br J Dermatol 129(5): 597-598.

61. Koziol J. A., Feng A. C. (2004). Seasonal variations in exacerbations and MRI parameters in relapsing-remitting multiple sclerosis. Neuroepidemiology 23(5): 217-223.

62. Kremer L., Mealy M., Jacob A., et al. (2013). Brainstem manifestations in neuromyelitis optica: a multicenter study of 258 patients. Mult Scler.

63. Kuroiwa Y., Araki S. (1963). Lhermitte's sign and reflex tonic spasm in demyelinating diseases with special reference to their localizing value. Kyushu $\mathbf{J}$ Med Sci 14: 29-38.

64. Lennon V. A., Wingerchuk D. M., Kryzer T. J., et al. (2004). A serum autoantibody marker of neuromyelitis optica: distinction from multiple sclerosis. Lancet 364(9451): 2106-2112.

65. Leray E., Yaouanq J., Le Page E., et al. (2010). Evidence for a two-stage disability progression in multiple sclerosis. Brain 133(Pt 7): 1900-1913.

66. Liu T., Berta T., Xu Z. Z., et al. (2012). TLR3 deficiency impairs spinal cord synaptic transmission, central sensitization, and pruritus in mice. J Clin Invest 122(6): 2195-2207.

67. Magraner M. J., Coret F., Casanova B. (2013). The effect of intravenous immunoglobulin on neuromyelitis optica. Neurologia 28(2): 65-72.

68. Mandler R. N., Ahmed W., Dencoff J. E. (1998). Devic's neuromyelitis optica: a prospective study of seven patients treated with prednisone and azathioprine. Neurology 51(4): 1219-1220.

69. Matiello M., Lennon V. A., Jacob A., et al. (2008). NMO-IgG predicts the outcome of recurrent optic neuritis. Neurology 70(23): 2197-2200.

70. Matthews W. B. (1958). Tonic seizures in disseminated sclerosis. Brain 81(2): 193-206.

71. Matthews W. B. (1975). Paroxysmal symptoms in multiple sclerosis. J Neurol Neurosurg Psychiatry 38(6): 617-623.

72. McKeon A., Lennon V. A., Lotze T., et al. (2008). CNS aquaporin-4 autoimmunity in children. Neurology 71(2): 93-100.

73. McLeod J. G., Barnett M. H., Macaskill P., Williams D. B. (2007). Long-term prognosis of multiple sclerosis in Australia. J Neurol Sci 256(1-2): 35-38.

74. Mealy M. A., Wingerchuk D. M., Palace J., et al. (2014). Comparison of relapse and treatment failure rates among patients with neuromyelitis optica: multicenter study of treatment efficacy. JAMA Neurol 71(3): 324-330.

75. Meier D. S., Balashov K. E., B. Healy, et al. (2010). Seasonal prevalence of MS disease activity. Neurology 75(9): 799-806. 
76. Miller F. G. (2008). Research on medical records without informed consent. J Law Med Ethics 36(3): 560-566.

77. MS pacienta karte: Ministru Kabineta 2008. gada 15. septembra noteikumu Nr. 746 13. pielikums. Retrieved 26.1.2015., from http://www.spkc.gov.lv/mediciniska-uzskaites-un-statistikas-dokumentacija

78. Mochizuki H., Kakigi R. (2014). Central mechanisms of itch. Clin Neurophysiol.

79. Mochizuki H., Papoiu A. D. P., Yosipovitch G. (2014). Brain Processing of Itch and Scratching. Itch: Mechanisms and Treatment. E. Carstens and T. Akiyama. Boca Raton (FL).

80. Mochizuki H., Tashiro M., Kano M., et al. (2003). Imaging of central itch modulation in the human brain using positron emission tomography. Pain 105(1-2): 339-346.

81. Murray T. J. (2009). The history of multiple sclerosis: the changing frame of the disease over the centuries. J Neurol Sci 277 Suppl 1: S3-8.

82. Muto M., Mori M., Sato Y., et al. (2013). Seasonality of multiple sclerosis and neuromyelitis optica exacerbations in Japan. Mult Scler 19(3): 378-379.

83. Muto M., Mori M., Sato Y., et al. (2015). Current symptomatology in multiple sclerosis and neuromyelitis optica. Eur J Neurol 22(2): 299-304.

84. Nakano T., Dei F., Kawamoto Y., et al (2014). Hypothermia and memory disturbance as initial manifestations associated with lesions of the diencephalon in a patient with anti-aquaporin 4 antibody-associated disorder: a case report. Rinsho Shinkeigaku 54(8): 653-656.

85. Oaklander A. L. (2011). Neuropathic itch. Semin Cutan Med Surg 30(2): 87-92.

86. Oaklander A. L. (2012). Common neuropathic itch syndromes. Acta Derm Venereol 92(2): 118-125.

87. Oaklander A. L. (2014). Neuropathic Itch. Itch: Mechanisms and Treatment. Carstens E., Akiyama T. Boca Raton (FL).

88. Ogawa G., Mochizuki H., Kanzaki M., et al. (2004). Seasonal variation of multiple sclerosis exacerbations in Japan. Neurol Sci 24(6): 417-419.

89. Oglesby A., Shaul A. J., Pokora T., et al. (2013). Adverse event burden, resource use, and costs associated with immunosuppressant medications for the treatment of systemic lupus erythematosus: a systematic literature review. Int J Rheumatol 2013: 347520 .

90. Okada K., Tsuji S., Tanaka K. (2007). Intermittent intravenous immunoglobulin successfully prevents relapses of neuromyelitis optica. Intern Med 46(19): 1671-1672.

91. Osterman P. O. (1976). Paroxysmal itching in multiple sclerosis. Br J Dermatol 95(5): 555-558.

92. Osterman P. O. (1979). Paroxysmal itching in multiple sclerosis. Int J Dermatol 18(8): 626-627. 
93. Ostermann P. O., Westerberg C. E. (1975). Paroxysmal attacks in multiple sclerosis. Brain 98(2): 189-202.

94. Palace J., Leite M. I., Jacob A. (2012). A practical guide to the treatment of neuromyelitis optica. Pract Neurol 12(4): 209-214.

95. Palace J., Leite M. I., Nairne A., A. Vincent (2010). Interferon Beta treatment in neuromyelitis optica: increase in relapses and aquaporin 4 antibody titers. Arch Neurol 67(8): 1016-1017.

96. Pandit L., Mustafa S., Kunder R., et al. (2013). Optimizing the management of neuromyelitis optica and spectrum disorders in resource poor settings: Experience from the Mangalore demyelinating disease registry. Ann Indian Acad Neurol 16(4): 572-576.

97. Pellkofer H. L., Krumbholz M., Berthele A., et al. (2011). Long-term follow-up of patients with neuromyelitis optica after repeated therapy with rituximab. Neurology 76(15): 1310-1315.

98. Pinto A. L., Chebli L. A., Ribeiro M. S., et al. (2009). Azathioprine therapy in steroid-dependent patients with Crohn disease: results of a 10-year longitudinal follow-up study. Med Sci Monit 15(5): PI19-26.

99. Pittock S. J., Lennon V. A., McKeon A., et al. (2013). Eculizumab in AQP4-IgGpositive relapsing neuromyelitis optica spectrum disorders: an open-label pilot study. Lancet Neurol 12(6): 554-562.

100. Pittock S. J., Mayr W. T., McClelland R. L., et al. (2004). Disability profile of MS did not change over 10 years in a population-based prevalence cohort. Neurology 62(4): 601-606.

101. Pittock S. J., Mayr W. T., McClelland R. L., et al. (2004). Change in MS-related disability in a population-based cohort: a 10-year follow-up study. Neurology 62(1): 51-59.

102. Pittock S. J., McClelland R. L., Mayr W. T., et al. (2004). Clinical implications of benign multiple sclerosis: a 20-year population-based follow-up study. Ann Neurol 56(2): 303-306.

103. Prefontaine E., Macdonald J. K., Sutherland L. R. (2010). Azathioprine or 6-mercaptopurine for induction of remission in Crohn's disease. Cochrane Database Syst Rev(6): CD000545.

104. Ramanathan S., Reddel S. W., Henderson A., et al. (2014). Antibodies to myelin oligodendrocyte glycoprotein in bilateral and recurrent optic neuritis. Neurol Neuroimmunol Neuroinflamm 1(4): e40.

105. Regidor E. (2004). The use of personal data from medical records and biological materials: ethical perspectives and the basis for legal restrictions in health research. Soc_Sci Med 59(9): 1975-1984.

106. Robling M. R., Hood K., Houston H., et al. (2004). Public attitudes towards the use of primary care patient record data in medical research without consent: a qualitative study. J Med Ethics 30(1): 104-109. 
107. Rolak L. A. (2003). MS: the basic facts. Clin Med Res 1(1): 61-62.

108. Rostasy K., Mader S., Schanda K., et al. (2012). Anti-myelin oligodendrocyte glycoprotein antibodies in pediatric patients with optic neuritis. Arch Neurol 69(6): 752-756.

109. Saadoun S., Waters P., Owens G. P., et al. (2014). Neuromyelitis optica MOG-IgG causes reversible lesions in mouse brain. Acta Neuropathol Commun 2: 35.

110. Sahasranaman S., Howard D., Roy S. (2008). Clinical pharmacology and pharmacogenetics of thiopurines. Eur J Clin Pharmacol 64(8): 753-767.

111. Sahraian M. A., Moinfar Z., Khorramnia S., Ebrahim M. M. (2010). Relapsing neuromyelitis optica: demographic and clinical features in Iranian patients. Eur J Neurol 17(6): 794-799.

112. Salvi F., Bartolomei I., Smolensky M. H., et al. (2010). A seasonal periodicity in relapses of multiple sclerosis? A single-center, population-based, preliminary study conducted in Bologna, Italy. BMC Neurol 10: 105.

113. Sandyk R. (1994). Paroxysmal itching in multiple sclerosis during treatment with external magnetic fields. Int J Neurosci 75(1-2): 65-71.

114. Sato D. K., Callegaro D., Lana-Peixoto M. A., et al. (2014). Seronegative Neuromyelitis Optica Spectrum - the challenges on disease definition and pathogenesis. Arq Neuropsiquiatr 72(6): 445-450.

115. Sato D., Fujihara K. (2011). Atypical presentations of neuromyelitis optica. Arq Neuropsiquiatr 69(5): 824-828.

116. Scalfari A., Neuhaus A., Daumer M., et al. (2011). Age and disability accumulation in multiple sclerosis. Neurology 77(13): 1246-1252.

117. Scalfari A., Neuhaus A., Degenhardt A., et al. (2010). The natural history of multiple sclerosis: a geographically based study 10: relapses and long-term disability. Brain 133(Pt 7): 1914-1929.

118. Shibasaki H., Kuroiwa Y. (1974). Painful tonic seizure in multiple sclerosis. Arch Neurol 30(1): 47-51.

119. Simon K., Schmidt H., Loud S., Ascherio A. (2014). Risk factors for multiple sclerosis, neuromyelitis optica and transverse myelitis. Mult Scler.

120. Spelman T., Gray O., Trojano M., et al. (2014). Seasonal variation of relapse rate in multiple sclerosis is latitude dependent. Ann Neurol 76(6): 880-890.

121. Su P. Y., Ko M. C. (2011). The role of central gastrin-releasing peptide and neuromedin $\mathrm{B}$ receptors in the modulation of scratching behavior in rats. J Pharmacol_Exp Ther 337(3): 822-829.

122. Sun Y. G., Chen Z. F. (2007). A gastrin-releasing peptide receptor mediates the itch sensation in the spinal cord. Nature 448(7154): 700-703.

123. Sun Y. G., Zhao Z. Q., Meng X. L., et al. (2009). Cellular basis of itch sensation. Science 325(5947): 1531-1534.

124. Suzuki K., Nakamura T., Hashimoto K., et al. (2012). Hypothermia, hypotension, hypersomnia, and obesity associated with hypothalamic lesions in a patient 
positive for the anti-aquaporin 4 antibody: a case report and literature review. Arch Neurol 69(10): 1355-1359.

125. Takanashi Y., T. Misu, K. Oda, et al (2014). Audiological evidence of therapeutic effect of steroid treatment in neuromyelitis optica with hearing loss. J Clin Neurosci 21(12): 2249-2251.

126. Timmer A., McDonald J. W., Tsoulis D. J., Macdonald J. K. (2012). Azathioprine and 6-mercaptopurine for maintenance of remission in ulcerative colitis. Cochrane Database Syst Rev 9: CD000478.

127. Tremlett H., Paty D., Devonshire V. (2006). Disability progression in multiple sclerosis is slower than previously reported. Neurology 66(2): 172-177.

128. Trojano M., Avolio C., Manzari C., et al. (1995). Multivariate analysis of predictive factors of multiple sclerosis course with a validated method to assess clinical events. J Neurol Neurosurg Psychiatry 58(3): 300-306.

129. Tsuburaya R. S., Miki N., Tanaka K., et al. (2015). Anti-myelin oligodendrocyte glycoprotein (MOG) antibodies in a Japanese boy with recurrent optic neuritis. Brain_Dev 37(1): 145-148.

130. Twycross R., Greaves M. W., Handwerker H., et al. (2003). Itch: scratching more than the surface. QJM 96(1): 7-26.

131. Usmani N., Bedi G., Lam B. L., Sheremata W. A. (2012). Association between paroxysmal tonic spasms and neuromyelitis optica. Arch Neurol 69(1): 121-124.

132. Viswanathan S., Arip M., Mustafa N., et al. (2014). The frequency of antiaquaporin-4 Ig g antibody in neuromyelitis optica and its spectrum disorders at a single tertiary referral center in malaysia. Mult Scler Int 2014: 568254.

133. Wang R., Qi D., Zhang Y. (2015). Neuromyelitis optica spectrum disorder initiated with hemiageusia and pruritus: A case report. J Neurol Sci 348(1-2): 288-289.

134. Watanabe S., Misu T., Miyazawa I., et al. (2007). Low-dose corticosteroids reduce relapses in neuromyelitis optica: a retrospective analysis. Mult Scler 13(8): 968-974.

135. Waters P., Vincent A. (2008). Detection of anti-aquaporin-4 antibodies in neuromyelitis optica: current status of the assays. Int MS J 15(3): 99-105.

136. Waubant E., Alize P., Tourbah A., Agid Y. (2001). Paroxysmal dystonia (tonic spasm) in multiple sclerosis. Neurology 57(12): 2320-2321.

137. Weinshenker B. G., Bass B., Rice G. P., et al. (1989). The natural history of multiple sclerosis: a geographically based study. I. Clinical course and disability. Brain 112 ( Pt 1): 133-146.

138. Weinstock-Guttman B., Miller C., Yeh E., et al. (2008). Neuromyelitis optica immunoglobulins as a marker of disease activity and response to therapy in patients with neuromyelitis optica. Mult Scler 14(8): 1061-1067.

139. Weinstock-Guttman B., Ramanathan M., Lincoff N., et al. (2006). Study of mitoxantrone for the treatment of recurrent neuromyelitis optica (Devic disease). Arch Neurol 63(7): 957-963. 
140. Wingerchuk D. M. (2013). Neuromyelitis optica: potential roles for intravenous immunoglobulin. J Clin Immunol 33 Suppl 1: S33-37.

141. Wingerchuk D. M., Hogancamp W. F., O'Brien P. C., Weinshenker B. G. (1999). The clinical course of neuromyelitis optica (Devic's syndrome). Neurology 53(5): $1107-1114$.

142. Wingerchuk D. M., Lennon V. A., Lucchinetti C. F., et al. (2007). The spectrum of neuromyelitis optica. Lancet Neurol 6(9): 805-815.

143. Wingerchuk D. M., Lennon V. A., Pittock S. J., et al. (2006). Revised diagnostic criteria for neuromyelitis optica. Neurology 66(10): 1485-1489.

144. Wingerchuk D. M., Pittock S. J., Lucchinetti C. F., et al. (2007). A secondary progressive clinical course is uncommon in neuromyelitis optica. Neurology 68(8): 603-605.

145. Wingerchuk D. M., Weinshenker B. G. (2003). Neuromyelitis optica: clinical predictors of a relapsing course and survival. Neurology 60(5): 848-853.

146. Woo P. Y., Chiu J. H., Leung K. M., Chan K. Y. (2014). Seropositive Neuromyelitis Optica imitating an Intramedullary Cervical Spinal Cord Tumor: Case Report and Brief Review of the Literature. Asian Spine J 8(5): 684-688.

147. Woodhall M., Coban A., Waters P., et al. (2013). Glycine receptor and myelin oligodendrocyte glycoprotein antibodies in Turkish patients with neuromyelitis optica. J Neurol Sci 335(1-2): 221-223.

148. Yamamoto K., Kawazawa S., Takase Y., et al. (1989). Paroxysmal itching and magnetic resonance imaging of the spinal cord in multiple sclerosis. Rinsho Shinkeigaku 29(11): 1345-1351.

149. Yamamoto M., Yabuki S., Hayabara T. , Otsuki S. (1981). Paroxysmal itching in multiple sclerosis: a report of three cases. J Neurol Neurosurg Psychiatry 44(1): 19-22.

150. Zhao S., Mutch K., Elsone L., et al. (2014). An unusual case of 'itchy paralysis': neuromyelitis optica presenting with severe neuropathic itch. Pract Neurol.

151. UK good clinical practice guidelines Retrieved 26.1.2015., from http://www.mhra.gov.uk/Howweregulate/Medicines/Inspectionandstandards/Good ClinicalPractice/ 


\section{PUBLIKĀCIJAS UN ZIN̦OJUMI PAR PẼTİJUMA TĒMU}

\subsection{Zinātniskie raksti starptautiski citējamos žurnālos saistībā ar darba tēzēm (pirmais autors)}

- Elsone L., Kitley J., Luppe S., Lythgoe D., Mutch K., Jacob S., Brown R., Moss K., McNeillis B., Goh Y.Y., Leite M.I., Robertson N., Palace J., Jacob A. Long-term efficacy, tolerability and retention rate of azathioprine in 103 aquaporin-4 antibody-positive neuromyelitis optica spectrum disorder patients: a multicentre retrospective observational study from the UK. Mult Scler. 2014 Oct; 20(11):1533-40. doi:10.1177/1352458514525870. Epub 2014 Mar 19. PMID: 24647557.

- Elsone L., Panicker J., Mutch K., Boggild M., Appleton R., Jacob A. Role of intravenous immunoglobulin in the treatment of acute relapses of neuromyelitis optica: experience in 10 patients. Mult Scler. 2013 Sep 2.

- Elsone L., Townsend T., Mutch K., Das K., Boggild M., Nurmikko T., Jacob A. Neuropathic pruritus (itch) in neuromyelitis optica. Mult Scler. 2013 Apr; 19(4):475-9. doi: 10.1177/1352458512457720.

\subsection{Konferenču tēzes publicētas starptautiski citējamos žurnālos saistībā ar darba tēzēm (pirmais autors)}

- Elsone L., Kitley J., Luppe S., Lythgoe D., Brown R., McNeillis B., Yen Goh Y., Mutch K., Jacob S., Leite M., Robertson N., Palace J., Jacob A. Is azathioprine effective in highly-active Neuromyelitis optica? A multicentre study from the United Kingdom. Multiple Sclerosis Journal 2013; 19: (S1) 233.

- Elsone L., Kitley J., Luppe S., Lythgoe D., Brown R., McNeillis B., Yen Goh Y., Mutch K., Jacob S., Leite M., Robertson N., Palace J., Jacob A. Long term efficacy, adherence and reasons for discontinuation in 103 cases of neuromyelitis optica treated with azathioprine: a multicentre study from the United Kingdom. Multiple Sclerosis Journal 2013; 19: (S1) 446. 
- Elsone L., Goh Y.Y, Trafford R., Mutch K., Jacob A. How often does respiratory failure occur in Neuromyelitis optica? J Neurol Neurosurg Psychiatry 2013; 84:11 e2 doi:10.1136/jnnp-2013306573.175

- Elsone L., Luppe S., Kitley J., Chater-Lea P., Harding K., Mutch K., Leite M.I., Palace J., Robertson N., Jacob A. Seasonal pattern of variation in neuromyelitis optica relapses. Multiple Sclerosis Journal 2012; 18: (S4) 279-508.

- $\quad$ Elsone L., Mutch K., Townsend T., Boggild M., Nurmikko T., Jacob A.. Neurogenic pruritus in neuromyelitis optica. J Neurol Neurosurg Psychiatry 2012; 83:Suppl. 2 A16-A17 doi:10.1136/jnnp-2012304200a.62.

- Elsone L., Townsend T., Mutch K., Das K., Boggild M., Jacob A. Tonic spasms in neuromyelitis optica. 16th Congress of the European Federation of Neurological Societies - EFNS (Stokholma, Zviedrija, 09/2012), konferences tēžu krājums.

\subsection{Publikācijas (zinātniskie raksti) par pētījuma tēmu}

- Rathnasabapathi D., Elsone L., Krishnan A., Young C., Larner A., Jacob A. Solitary Sclerosis: Progressive neurological deficit from a spatially isolated demyelinating lesion - A further report. The Journal of Spinal Cord Medicine (2014). Pieñemts publicēšanai (references Nr. JSCM-D-14-00027R2).

- Zhao S., Mutch K., Elsone L., Miller J., Jacob A. An unusual case of 'itchy paralysis': neuromyelitis optica presenting with severe neuropathic itch. Pract Neurol. 2014 Nov 17. pii: practneurol-2014000936. doi: 10.1136/practneurol-2014-000936. [Epub ahead of print].PMID:25404417.

- Iyer A., Rathnasabapathi D., Elsone L., Mutch K., Terlizzo M., Footitt D., Jacob A. Transverse myelitis associated with an itchy rash and hyperCkemia: neuromyelitis optica associated with dermatitis herpetiformis. JAMA Neurol. 2014 May; 71(5): 630-3. doi: 10.1001/jamaneurol.2013.6277. PMID:24637913.

- Iyer A., Elsone L., Appleton R., Jacob A. A review of current literature and guide to the early diagnosis of the autoimmune disorders 
associated with neuromyelitis optica. JAMA Neurol (2014) Autoimmunity, Early Online: 1-9. PMID:24512514.

- Zhao S., Mutch K., Elsone L., Nurmikko T., Jacob A. Neuropathic pain in neuromyelitis optica affects activities of daily living and quality of life. Mult Scler. 2014 Feb 5. PMID:24493470.

- Michael B.D., Elsone L., Griffiths M. J., Faragher B., Borrow R., Solomon T., Jacob A. Post-acute serum eosinophil and neutrophilassociated cytokine/chemokine profile can distinguish between patients with neuromyelitis optica and multiple sclerosis; and identifies potential pathophysiological mechanisms - a pilot study. Cytokine. 2013 Oct; 64(1): 90-6. doi: 10.1016/j.cyto.2013.07.019.

- Collongues, N., Marignier R., Jacob A., Leite M., Siva A., Paul F, Elsone L. et al. Characterization of neuromyelitis optica and neuromyelitis optica spectrum disorder patients with a late onset. Mult Scler.2013. doi:10.1177/1352458513515085.

- Kremer L., Mealy M., Jacob A., Nakashima I., Cabre P., Bigi S., Paul F., Jarius S., Aktas O., Elsone L. et al. Brainstem manifestations in neuromyelitis optica: a multicenter study of 258 patients. Mult Scler. 2013 Oct 7.

- Kitley J., Leite M. I., Elsone L., Jacob A., Palace, J. (2013). Time to next relapse as a primary endpoint in neuromyelitis optica clinical trials. J Neurol Neurosurg Psychiatry. doi:10.1136/jnnp-2013-306541.

- Kitley J., Elsone L., George J., Waters P., Woodhall M., Vincent A., Jacob A., Leite M.I., Palace J. Methotrexate is an alternative to azathioprine in neuromyelitis optica spectrum disorders with aquaporin-4 antibodies. J Neurol Neurosurg Psychiatry. 2013 Aug;84(8):918-21. doi: 10.1136/jnnp-2012-304774. Epub 2013 Mar 6.

- Jacob A., Panicker J., Lythgoe D., Elsone L., Mutch K., Wilson M., Das K., Boggild M.J. The epidemiology of neuromyelitis optica amongst adults in the Merseyside county of United Kingdom. Neurol. 2013 Aug; 260(8): 2134-7. doi: 10.1007/s00415-013-6926-y.

- Jacob A., McKeon A., Nakashima I., Sato D.K., Elsone L., Fujihara K., de Seze J. Current concept of neuromyelitis optica (NMO) and NMO spectrum disorders. J Neurol Neurosurg Psychiatry. 2013 Aug;84(8):922-30. doi: 10.1136/jnnp-2012-302310. 
- Jacob A., Hutchinson M., Elsone L., Kelly S., Ali R., Saukans I., Tubridy N., Boggild M. Does natalizumab therapy worsen neuromyelitis optica? Neurology. 2012 Sep 4;79(10):1065-6. doi: 10.1212/WNL.0b013e31826845fe.

- Kitley J., Leite M. I., Nakashima I., Waters P., McNeillis B., Brown R. Elsone L., et al. Palace, J. Prognostic factors and disease course in aquaporin-4 antibody-positive patients with neuromyelitis optica spectrum disorder from the United Kingdom and Japan.. Brain 2012:135(Pt 6), 1834-1849. doi:10.1093/brain/aws109, PMID: 22577216.

- Elsone L., Platkajis A., Karelis G., Saukans I.. Frequency and Localization of spinal cord demyelination in MS patients, coexistence of intervertebral disc protrusion. Acta Chirurgica Latviensis.2011 (11).

- Elsone L., Platkājis A., Karelis G. et al. Tumefactive Multiple Sclerosis mimicking Neoplasm. Acta CHIRURGICA Latviensis. 2010; 378.-384. lpp.

- Elsone L., Platkājis A., Karelis G. Pasaules literatūras datu par multiplās sklerozes izplatības tendencēm salīdzinājums ar multiplās sklerozes epidemiologisko situāciju Latvijā. RSU zinātnisko rakstu krājums 2010.

\subsection{Konferenču tēzes par pētījuma tēmu}

- Kitley J., Kattenbelt M., Waters P., Woodhall M., George J., Elsone L., Jacob A., Leite M.I., Palace J., Vincent A. Alternative antigen targets in aquaporin-4 antibodynegative neuromyelitis optica spectrum disorders. Multiple Sclerosis Journal 2013; 19: (S1) 83.

- Kitley J., Leite M. I., Elsone L., Jacob A., Palace J. Time to next relapse as a primary endpoint in Neuromyelitis optica clinical trials. Multiple Sclerosis Journal 2013; 19: (S1) 331.

- Rathnasabapathi D., Elsone L., Jacob A. Progressive neurological deficit from a solitary spatially isolated demyelinating lesion: solitary sclerosis - the first series from the UK. J Neurol Neurosurg Psychiatry 2013; 84:11 e2 doi:10.1136/jnnp-2013-306573.187.

- Mutch K., Methley A., Ennis M., Elsone L., Jacob A. Effects of fatigue on neuromyelitis optica. Multiple Sclerosis Journal 2013; 19: (S1) 308 . 
- Zhao S., Mutch K., Elsone L., Nurmikko T., Jacob A. Pain in Neuromyelitis optica is under-recognised but disabling symptom. J Neurol Neurosury Psychiatry 2013;84:11 e2 doi:10.1136/jnnp-2013306573.195.

- $\quad$ Kremer L., Mealy M., Jacob A., Nakashima I., Cabre P., Bigi S., Paul F., Jarius S., Aktas O., Elsone L., Mutch K., Levy M., Takai Y., Collongues N., Banwell B., Fujihara K., de Seze J. Multiple Sclerosis Journal 2012; 18: (S4) 279-508.

- Collongues N., Marignier R., Jacob A., Siva A., Paul F., Zephir H., Leite M.I., Akman-Demir G., Elsone L., et al. Characterization of NMO and NMOSD patients with a late onset. Multiple Sclerosis Journal 2012; 18: (S4) 279-508.

- Kitley J., Elsone L., George J., Jacob A., Leite M. I., Palace J. Methotrexate may be an alternative to azathioprine in neuromyelitis optica with aquaporin-4 antibodies. Journal of Neurology, Neurosurgery and Psychiatry. 2012:(83). doi:10.1136/jnnp-2012304200a.70.

- Vainsteine L., Kozica D., Karelis G., Elsone L. Risk of developing multiple sclerosis after clinically isolated optic neuritis in Latvian patients. EFNS Septembris 2012. Konferences tēžu krājums.

- Elsone L., Platkajis A., Karelis G., Murzina M. Frequency of spinal cord cord lesions and correlation with clinical presentation of multiple sclerosis in Latvian patients. Lisabona, Portugāle. ENS. 2011., maijs. konferences tēžu krājums.

- Elsone L., Platkājis A., Mētra M., Kalniņa J., Paegle A., Karelis G. Retrospektīva datu analīze par imūnmodulējošas terapijas pielietojumu multiplās sklerozes slimniekiem Latvijā. Rīgas Stradiṇa universitātes 2011. gada zinātniskās konferences tēzes

- Elsone L., Platkājis A., Karelis G. Klīniski prognostiskie rādītāji multiplās sklerozes slimniekiem Latvijā. Rīgas Stradiṇa universitātes 2010. gada zinātniskās konferences tēzes.

- Mētra M., Elsone L., Kalniņa J., Paegle A. Imūnmodulējošas terapijas retrospektīva datu analīze MS pacientiem. Latvijas Jūras Medicīnas Centra 2010. gada zinātniskās konferences tēzes.

- Klīniskā paasinājuma izvērtējums pacientiem ar multiplo sklerozi un mugurkaula kakla daļas spondilozi. Kalniņa J., Mētra M., Dzelzīte S., 
Murziņa M., Paegle A., Elsone L. Latvijas Jūras Medicīnas Centra 2010. gada zinātniskās konferences tēzes.

- Multiplās sklerozes centra datu bāzes analīze uz 2009. gada 15. decembri. Mētra M., Kalniņa J., Paegle A., Murziņa M., Elsone L. Latvijas Jūras Medicīnas Centra 2010. gada zinātniskās konferences tēzes.

\subsection{Ziṇojumi konferencēs par darba rezultātiem}

- Elsone L., Panicker J., Mutch K., Boggild M., Appleton R., Jacob A. Role of intravenous immunoglobulin in the treatment of acute relapses of neuromyelitis optica: experience in 10 patients. AAN (stenda referāts, Sandjego, ASV, 03/2013).

- Elsone L., Kitley J., Luppe S., Lythgoe D., Brown R., McNeillis B., Goh Y.Y., Mutch K., Jacob S., Leite M., Robertson N., Palace J., Jacob A. Is azathioprine effective in highly-active Neuromyelitis optica? A multicentre study from the United Kingdom. ECTRIMS (stenda referāts, Kopenhāgena, Dānija, 10/2013).

- Elsone L., Kitley J., Luppe S., Lythgoe D., Brown R., McNeillis B., Goh Y.Y., Mutch K., Jacob S., Leite M., Robertson N., Palace J., Jacob A.. Long term efficacy, adherence and reasons for discontinuation in 103 cases of neuromyelitis optica treated with azathioprine: a multicentre study from the United Kingdom. ECTRIMS (stenda referāts, Kopenhāgena, Dānija, 10/2013).

- Elsone L., Luppe S., Kitley J., Chater-Lea P., Harding K., Mutch K., Leite M.I., Palace J., Robertson N., Jacob A. Seasonal pattern of variation in neuromyelitis optica relapses. ECTRIMS (stenda referāts, Liona, Francija, 10/2012).

- Elsone L.,_ Mutch K., Townsend T., Boggild M., Nurmikko T., Jacob A. Neurogenic pruritus in neuromyelitis optica. ABN (stenda referāts, Lielbritānija, 05/2012).

- Elsone L., Townsend T., Mutch K., Das K., Boggild M., Jacob A. Tonic spasms in neuromyelitis optica. 16th Congress of the European Federation of Neurological Societies - EFNS (stenda referāts, Stokholma, Zviedrija, 09/2012). 
- Elsone L., Leite M.I., McNeillis B., Brown R., Palace J., Boggild M., Jacob A. Treatment of Neuromyelitis Optica with Azathioprine. ABN (stenda referāts, Lielbritānija, 10/2011).

- Elsone L., Mutch K. and Jacob A. IVIG in NMO Refractory/Intolerant to Rituximab. ABN. (stenda referāts, Lielbritānija, Kārdifa, 05/2014).

- Elsone L., Waters P., Woodhall M., Jacob A. Relapsing AQP4 antibody negative NMO with MOG antibodies. ABN. (stenda referāts, Lielbritānija, Kārdifa, 05/2014). 


\section{PATEICĪBAS}

Sirsnīgi pateicos mana promocijas darba vadītājiem asoc. prof. Ardim Platkājim un doc. Guntim Karelim par disertācijas darba koordinēšanu, vērtīgajiem zinātniskiem padomiem un atbalstu darba tapšanā, kā arī disertācijas dizaina izstrādē. Viennozīmīgi milẓ̄̂gs paldies jāsaka darba zinātniskam konsultantam un "NMO" zinātniskā projekta vadītājam $D r$. Anu Jacob no Valtonas Neirologijas un neiroķirurgíijas centra Liverpūlē, Lielbritānijā, kas sniedza savas neatkārtojamās zināšanas un milzīgu atbalstu gan motivēšanā un apmācībā, gan pētījumu dizaina izveidē, to vadīšanā, rezultātu apstrādē un analīzē, kā arī publikāciju tapšanā. Pētījumu statistiskā apstrāde, izṇemot apakšpētījumā par sezonalitāti, veikta sadarbībā ar D. Lithgoe no Liverpūles universitātes Lielbritānijā. Statistiskā apstrāde pētījumā par sezonalitāti veikta sadarbībā ar K. Harding no Kārdifas Universitātes. Darbs nebūtu iespējams arī bez citu Lielbritānijas kolẹgu atbalsta, tajā skaitā neirologiem no visas Apvienotās Karalistes, kas nosūtīja pacientus uz NMO centru Liverpūlē, kā arī palīdzēja datu kolekcionēšanā. Paldies, jāsaka arī LJMC kolektīvam, jo īpaši Dr. M. Métrai un profesorei V. Eniņai, par iepazīstināšanu ar demielinizējošām saslimšanām un motivēšanu neapstāties pie sasniegtā. Darba literāro detaļu saskaņošana (t. sk. terminu latviskošana) veikta sadarbībā ar Rīgas Stradiña universitātes izdevniecību (redaktori I. Galiņu). Milzīgs paldies arī viņai par veltīto laiku.

Visdziḷāko pateicību pelnījusi arī ğimene, jo īpaši vīrs, kā arī draugi, bez kuru nesavtīgā atbalsta un pacietības šo darbu nebūtu bijis iespējams pabeigt. Darbs tapis un prezentēts starptautiskās konferencēs ar nacionālās NMO programmas Lielbritānijā un Eiropas Sociālā fonda projekta "Atbalsts doktorantiem studiju programmas apguvei un zinātniskā grāda ieguvei Rīgas Stradiņa universitātē" finansiālu atbalstu. 